\title{
Weapons of Mass Distraction: 9/11 and Bush's Window of Opportunity into a State of Exception
}

By

Melissa Koluksuz, B.A. (Honours)

A thesis to the Faculty of Graduate Studies and Research in partial fulfillment of the requirements for the degree of

\author{
Master of Arts \\ Department of Geography and Environmental Studies
}

\author{
Carleton University \\ Ottawa, Ontario \\ 2010
}

(C) 2010

Melissa Koluksuz 


$\begin{array}{ll}\begin{array}{l}\text { Library and Archives } \\ \text { Canada }\end{array} & \begin{array}{l}\text { Bibliothèque et } \\ \text { Archives Canada }\end{array} \\ \begin{array}{l}\text { Published Heritage } \\ \text { Branch }\end{array} & \begin{array}{l}\text { Direction du } \\ \text { Patrimoine de l'édition }\end{array} \\ \begin{array}{l}\text { 395 Wellington Street } \\ \text { Ottawa ON K1A ON4 } \\ \text { Canada }\end{array} & \begin{array}{l}\text { 395, rue Wellington } \\ \text { Ottawa ON K1A ON4 } \\ \text { Canada }\end{array}\end{array}$

Your file Votre référence

ISBN: 978-0-494-71682-3

Our file Notre référence

ISBN: 978-0-494-71682-3

NOTICE:

The author has granted a nonexclusive license allowing Library and Archives Canada to reproduce, publish, archive, preserve, conserve, communicate to the public by telecommunication or on the Internet, loan, distribute and sell theses worldwide, for commercial or noncommercial purposes, in microform, paper, electronic and/or any other formats.

The author retains copyright ownership and moral rights in this thesis. Neither the thesis nor substantial extracts from it may be printed or otherwise reproduced without the author's permission.
AVIS:

L'auteur a accordé une licence non exclusive permettant à la Bibliothèque et Archives Canada de reproduire, publier, archiver, sauvegarder, conserver, transmettre au public par télécommunication ou par l'Internet, prêter, distribuer et vendre des thèses partout dans le monde, à des fins commerciales ou autres, sur support microforme, papier, électronique et/ou autres formats.

L'auteur conserve la propriété du droit d'auteur et des droits moraux qui protège cette thèse. Ni la thèse ni des extraits substantiels de celle-ci ne doivent être imprimés ou autrement reproduits sans son autorisation.
In compliance with the Canadian Privacy Act some supporting forms may have been removed from this thesis.

While these forms may be included in the document page count, their removal does not represent any loss of content from the thesis.
Conformément à la loi canadienne sur la protection de la vie privée, quelques formulaires secondaires ont été enlevés de cette thèse.

Bien que ces formulaires aient inclus dans la pagination, il n'y aura aucun contenu manquant.

\section{Canadä}




\begin{abstract}
The events of September $11^{\text {th }} 2001$ quickly changed the world, and the face of international politics for years to come. It proved to be the perfect excuse for the Bush administration to implement a doctrine that had been planned for well over a decade, engineered primarily by Project for the New American Century. The immediate fallout from September $11^{\text {th }}$, coupled with the declaration of a Global War on Terror propelled the United States from a state of emergency to being in a state of exception. This thesis analyzes states of exception, the geographical dimensions of power and security, and their implications. The thesis will conclude that $9 / 11$ was but an excuse to implement an agenda with a pre-existing blueprint and furthermore, will demonstrate that the Global War on Terror is merely a factor in America's overhaul of domestic and foreign policy in an attempt to obtain greater global dominance.
\end{abstract}




\section{Acknowledgements}

I would first like to thank Simon Dalby, my supervisor, and Trevor Purvis for your invaluable guidance throughout this entire process. I would also like to thank you for keeping me sane, encouraging me, pushing me and helping me grow as an academic and as a person. It has been an amazing experience, and I could not have come this far without you both, and for that I am deeply grateful.

To my mom and dad, who taught me the importance and value of a good education from a young age, thank you. You have always believed in me, listened to me when I was stressed, helped me through all of the hard times, and supported me from day one of this journey. Most of all I would like to thank you for your unconditional love.

To my one and only sister, Burcu Danisman, although we are far away you are always in my heart. I could always hear you cheering all the way from Istanbul.

To Parastou Asghari, my best friend, and the only person who knows me inside out - your encouragement and support has been endless and I love you so much.

To R.A.O.F - you have been my biggest fan. Thank you for always being there, and believing in me, even when I doubted myself.

In loving memory of Professor H. H. Gunhan Danisman 


\section{Table of Contents}

Abstract.................................................................... ii

Acknowledgements........................................................ iii

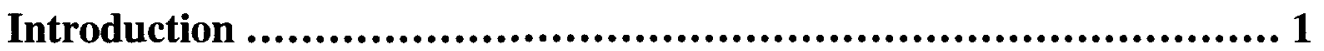

Chapter 1........................................................................... 24

States of Exception: Exploring the Exception(al), Political, and (II)legal

Chapter 2....................................................................... 42

States of Exception: A Geopolitical Analysis

Chapter 3.................................................................... 65

Axis of Evil: The Project for the New American Century

Chapter 4......................................................................... 88

Window of Opportunity: The Birth of the Bush Doctrine

Chapter 5...................................................................113

Weapons of Mass Distraction: How America Entered a State of Exception

Conclusion....................................................................134

Mission Accomplished

Afterword....................................................................156

Change we can believe in? 


\section{INTRODUCTION}

"9/11 was an amazing gift - as twisted and cruel as that sounds. It was an invitation from history, albeit one with a horrific price tag". - Thomas P. M. Barnett

September $11^{\text {th }} 2001$ proved to be the perfect excuse for the Bush administration to put into place a doctrine that had been planned for over a decade. With the tragedies of 9/11 and the never ending Global War on Terror (GWOT), the United States went from a state of emergency to quickly being in a state of exception. Agamben identifies the State of Exception as constituting

"A point of imbalance between public law and political fact that is situated like civil war - insurrection and resistance - in an ambiguous, uncertain, borderline fringe, at the intersection of the legal and political... The question of borders becomes all the more urgent: if exceptional measures are the result of periods of political crises and, as such, must be understood on political and not juridico-constitutional grounds, then they find themselves in the paradoxical position of being juridical measures that cannot be understood in legal terms, and the state of exception appears as the legal form of what cannot have legal form" (Agamben, 2005, p. 1).

In this quote, Agamben covers several facets of states of exception. A contested area of study, and one that is difficult to define, Agamben is suggesting that a state of exception is neither really within nor outside the legal order. The confusion is in whether or not to accept the state of exception as a legal term. The sovereign may declare a state of exception, and since he is the decider of this exceptional situation, he renders it "legal". However, the state of exception means that anything can be legalized, justified or legitimized by the sovereign, and therefore things that are normally "illegal", take on a somewhat legal form. Additionally, states of exception are called for situations relating to 
political crisis, and therefore Agamben argues that it is at the cross path of politics and law.

The way that this thesis will explore states of exception is in its relation to America post $9 / 11$ in specific, and American power and authority in general. The state of exception is a powerful tool that can be used to legitimize a number of policies, military actions and the reorganization of government. The aftermath from the attacks of September $11^{\text {th }}$ conveniently fell in the lap of Republican President George W. Bush and his crew. It could not have been a more perfect situation for Bush's administration to implement many domestic policies that would change the constitutional rights of citizens (minorities in specific), expand government control over the population, and on a larger scale, change global relations. This is especially problematic to Americans who are amongst the most nationalistic populations, and much of their pride stems from their founding history and Constitution. In theory, the American Constitution is the supreme law of the land, and is based on a very democratic and free society. Famously referred to mainly for its system of checks and balances, the Constitution is the backbone of American society, and additionally, the oldest Constitution still in use today. That being said, it is very troublesome that in a state of exception, the sovereign can suspend the constitutional rights of its citizens, taking away their basic rights and freedoms. Because of the importance of the Constitution to Americans and their daily life, the implications of a state of exception are much more threatening to their identity as a nation built on rights, equality, freedom and democracy. 
To reiterate, the idea that America has the right to assert its power and be a global leader is not a new idea and has been present since the days of the Munroe Doctrine. In 1823 "Monroe reinforced the constitutional right of the president to take the initiative in establishing American policy" (Nelson 1999, p. 54). The Munroe Doctrine was passed without any consultation with congress, and declared that the "new world of the Americas be off limits to any attempts at colonization by the "old world" of Europe" (Nelson 1999, p. 53). With that, Americans administrations were deciding what other nations could and could not do. In the opening paragraphs of Overthrow, Stephen Kinzer has this to say about America's history in regime change:

"The invasion of Iraq in 2003 was not an isolated episode. It was the culmination of a 110 -year perdio during which American overthrew fourteen governments that displeased them for various ideological, political, and economic reasons" (Kinzer 2006, p. 1).

After 1898 and the Spanish-American war, a new America emerged, according to Kinzer. It marked "the beginning of an era in which the United States has assumed the right to intervene anywhere in the world, not simply be influencing or coercing foreign governments but also by overthrowing them" (Kinzer 2006, p. 3). Kinzer notes that throughout the twentieth, and into the beginning of the twenty-first century, the United States used its military powers to overthrow governments, using a variety of excuses from national security and liberation, to the protection of American interests, economy, and to spread democracy (Ibid). The point of using Kinzer's argument here, is simply to show the continuity in the themes of American dominance. Invading other countries, and overthrowing governments, as in Iraq, is not new and needs to be made clear that that is not what was new about Iraq, the GWOT or the aftermath of $9 / 11$. 
Bush's request and permission for greater presidential powers is not the first time in American history that a President has request and received those powers either. 9/11 is just one of many instances where an emergency situation led to decisions by congress to grant increased powers for the president. In the case of the September $11^{\text {th }}$ attacks, declaring a state of emergency is not what is unusual. It has been done in the past, especially during times of war. It is the reason why the Bush administration saw it to be an emergency. The reason was specifically because they saw $9 / 11$ to have changed geographical conceptions of danger. It presented a clear shift in how we conceive danger, how it should be handled, and what its consequences are. The perception that danger is everywhere, doesn't have a territory, and can strike America on American soil represents a significant change. Therefore, 9/11 does not present a different situation in the desires of the executive branch to gain more power, as that fact alone has quite a history. In many instances in the past, war has been the time when presidents are granted extra powers. Schlesinger argues that "the assertions of sweeping and unilateral presidential authority remained official doctrine in foreign affairs" (Schlesinger 1973, p. ix) and certainly did not begin with Bush or $9 / 11$ by any means. Schlesinger writes

"The all-purpose invocation of 'national security', the insistence on executive secrecy, the withholding of information from Congress, the refusal to spend funds appropriated by Congress, the attempted intimidation of the press, the use of the White House itself as a base for espionage and sabotage directed against the political opposition - all signified the extension of the imperial Presidency from foreign to domestic affairs" (Schlensinger 1973 , p. iv).

Many similarities can be drawn between the above passage and the situation of America under president Bush. Perhaps with homeland security replacing national security, executive decisions about war and peace were made by the president, and 
secrecy of government operations were also concerns during the Bush years. Specific parallels can be drawn between Pearl Harbour and the presidential reactions, and 9/11 and Bush's reactions. Schlesinger argues that once Congress had declared war after Pearl Harbour, "Roosevelt seized on the role of Commander in Chief with relish" and he "preferred the title Commander in Chief to that of President" (Schlensinger 1973, p. 114). Consistently President Bush referred to himself as the "War-time President" and "Commander in Chief". He saw himself as the leader in times of war and emergency, much like Roosevelt. Like Bush, Roosevelt used war as an excuse to increase his authority, and "even more on the emergency powers released by his proclamations of 1939 and 1941 and stuffed into an all-purpose agency, the Office of Emergency Management" (Schlensinger 1973, p. 115). This Office provided the legal base for everything from war production to information, transportation, economic warfare and several other facets (Ibid). Comparable in theory to the Patriot Act, wartime and "emergency measures" allowed the president to control several aspects of everyday life domestically.

Several other parallels can be drawn and are worth noting to place Bush's initiatives in a historical context. When Johnson send 22,000 troops into the Dominican Republic without congressional consent, he declared that "we don't propose to sit here in our rocking chair with our hands folded and let the Communists set up any government in the Western Hemisphere" (Schlensinger 1973, p. 173). Similar to the idea that Bush does not wish to wait around until terrorists strike again, and wait for the "mushroom cloud" in 
American cities, Johnson was also advocating preemption. Again, not a new idea - or one originated by the Bush Doctrine, preemption has a long history in the United States.

Very similar to Colin Powell's speech at the United Nation regarding the "evidence" he found regarding Iraq, perhaps the most relevant historical comparison would be the Tonkin Gulf resolution under Johnson in 1964. The resolution was "rushed through Congress in August 1964 in a stampede of misinformation and misconception, if not of deliberate deception" (Schlensinger 1973, p. 179). The end result was that Congress approved and supported "the determination of the President, as Commander in Chief, to take all necessary measures to repel any armed attack against the forces of the Untied States and to prevent further aggression" (Ibid). Almost identical to the powers granted to Bush post $9 / 11$ in response to the attacks and in order to keep America safe, the Tonkin Gulf resolution is an example that Presidential powers have been granted and abused in the past. Presidents have always used emergencies as the excuse to expand their powers. Just as 9/11 allowed the President to do things he was not allowed to do before, at the time the Tonkin Resolution gave the President authority "to use force as he saw fit in vague future contingencies was precisely the sort of resolution rejected as unacceptable in the early republic" (Schlensinger 1973, p. 180). Before 9/11, the foreign and domestic policies that were implemented would also not be "allowed", however, emergency situations and times of war change everything.

That being said 9/11 is different. From the time of the Munroe Doctrine in 1823 to Tonkin Gulf in 1964, to the events in 2001 are all big stretches of time - and all exhibit 
serious social and cultural change. The situation in 2001 is very different from the events of 1970 . Human rights and freedoms, and human equality have come a long way. Many of the racial discriminations have been eliminated (although many still exist) and equality for all has made leaps since then. Therefore, to revert to a time when minorities are being questioned and detained while trying to fly to their homes in the Middle East for example, or racial profiling suddenly increases, is a big change from immediately before. Additionally, as mentioned, the geography of $9 / 11$ is substantially different than that of Pearl Harbour or the Tonkin Gulf incident. This was not an attack by a nation state on another. This is not a conventional war, and although Presidential powers have been extended, and emergency situation declared many times in the past, 9/11 does present a unique case, and is worth considering as something new amongst this discussion. Just the shock value of $9 / 11$ and the scale on which it happened also make for a unique case, and one worth identifying as something new.

In recent history, the election of George W Bush revived the idea of America's dominance and the expansion of presidential powers. It's foundational ideas were brought about by think tank Project for the New American Century (PNAC), the documents the organization had put forward eventually set the foundations for the Bush Doctrine. PNAC's involvement advocated a specific "set of priorities and a geopolitical framework for a Grand Strategy based on military supremacy against any potential state rivals to American power" (Dalby 2005a, p. 9). I plan to analyze 9/11 as something "new", given its geographical context. As a different kind of emergency than those previously called, this thesis will use a geopolitical framework to understand how this is a new emergency. 
The territorial aspects of the War on Terror will be a key part of this analysis. How territory and sovereignty relate in the GWOT are much different than those of typical situation of war between nation states that we have seen in the past. To reiterate this point, in a poorly worded statement George W Bush said,

"See, September the 11th changed the equation. It used to be that oceans would protect us, that we saw a threat, we didn't have to worry about it because there was two vast oceans. And we could pick and choose as to how we deal with the threat. That changed on September the 11th." (Bush 2004)

What Bush is trying to say is that he thinks the geography of danger has changed. America was attacked on their own soil, and not by another nation state. Danger, according to Bush, cannot be contained anymore; it is everywhere. Foreign policies that America implemented are outdated for dealing with this "new" threat. Whereas geography could stop attacks before, in a globalized world they cannot. Where borders and territories used to keep the invaders out - they have found new ways in. This thesis will approach $9 / 11$ as something new, based on the new geographical categories and assumptions that were created because of it. The geographical dimensions of power, danger and fear will also be a part of the discussion, as the shock and fear of Americans immediately after $9 / 11$, and the inability to process what has happened in the "old" framework of thinking played a big part in the response of the American administration.

The invasion of Iraq was central to the new strategy of preventive war, and a serious sign of America's increasing reality as being in a permanent state of exception. As the United Nations did not approve the war, nor did the international community, the war in Iraq takes place 
"Largely outside the framework of domestic or international law and seems to consolidate something akin to a permanent state of exception, in which distinctions such as inside/outside, peace/war, friend/enemy and rule/exception are blurred to the point of indistinction" (Van Muster 2004, p. 142).

Technically, in a state of exception, because there is no law, to call the war illegal would be irrelevant, which is why this particular situation is understood to be a "grey zone", where legal and illegal are blurred. The War on Terror in regards to U.S. actions in Afghanistan post 9/11 had support of the United Nations and NATO, and therefore the "illegal" war that is most often referred to is in reference to the invasion of Iraq, where there was not enough evidence and support for the United Nations to approve it. There has been a lot of scrutiny and analysis of $9 / 11$ and the Bush administration's reactions and what that has meant for policy implications, international relations and domestic rights and values. However, it would be beneficial to turn to critical geopolitics to critically assess the rationale for war. The Bush Doctrine was introduced as a set of documents and speeches post 9/11. It advocates pre-eminence, preventive war and unilateralism as its main principles. Codified in the National Security Strategy (NSS) of 2002, and put to practice in the invasion of Iraq, The Bush Doctrine is a central component to this argument. The analysis will focus on the connections between the influences of the Bush Doctrine, before Bush was president, to how they evolved during his presidency with the attacks of $9 / 11$ and actions taken by the administration afterwards (i.e. the invasion of Iraq). 
Much has been written about the aftermath of the attacks from policy implications to matters of domestic and international law, to international relations. Marking a turning point in world politics, September 11th has had profound effects on the international system and, thus, almost every discipline in the social sciences has generated theories from a variety of angles. This thesis looks at $9 / 11$ and its aftermath from a critical geopolitical perspective by asking questions aimed at understanding how 9/11 was used as a window of opportunity by the recent Bush administration, changing the face of geopolitics. The major question bring raised is how have the geographical perceptions of danger changed after $9 / 11$ allowing its consequences to be used as an opportunity by the Bush administration to implement a pre-planned agenda to propel America into being in a state of exception?

One of the biggest debates, and one that Agamben points out as being so, suggests that the differences in the legal traditions on states of exception,

"Correspond in scholarship to the division between those who seek to include the state of exception within the sphere of the juridical order and those who consider it something external, that is, an essentially political, or in any case extra juridical, phenomenon" (Agamben 2005, p. 22).

This will be one of the issues discussed throughout this thesis, as the state of exception is a grey zone, and still an area of contestation among geographers and other theorists. However, much has been missed when conceptualizing September $11^{\text {th }}$, the Global War on Terror (GWOT), The Bush Doctrine and the invasion of Iraq. A lot of these issues have been studied from a legal standpoint or a political science state-centric approach. The legal view does not comprehensively explain the rationale for war and the 
political science view doesn't take into account actors outside the state. It is useful to look into the geopolitics of America as being in a "state of exception", and to furthermore analyze 9/11 as a "window of opportunity", which hasn't had much attention as of yet. This is a more conclusive and interdisciplinary approach that is more telling of the events, their outcomes and potential futures.

Geopolitics is analysis at the largest scale. It is about

"The political organization of space, and about how this is conceived, represented and used in political discussion. The term refers to power at the largest of scales and simultaneously to the geographical arrangements of that power" (Dalby 2009, p. 235).

However, critical geopolitics presents us with a unique way to analyze this topic. A hybrid of several disciplines, critical geopolitics as a framework is an encompassing approach to the study of $9 / 11$ and the various issues outlined earlier. Dalby writes that

"Rather than a single analytical or methodological endeavour, critical geopolitics encompasses various ways of unpacking the geographical assumptions in politics.... and challenges common sense and "modern" assumptions that national identities and the states that govern populations are the necessary starting point for both policy discussion and scholarly analysis" (Dalby, 2010, p.51).

Critical geopolitics asks that we think outside the box, and move towards a more encompassing analysis of world issues. It is also a tool for understanding how these boxes were constructed in the first place. "This framework also allows us to question power and danger in world issues, such as threats, conflicts and war (O Tuathail 2006, p. 2). Additionally, critical geopolitics is very current and being continually updated. Although it draws on theories of the past, it is an evolving framework, drawing upon both 
the present and the past to explain international relations/world issues. 9/11 has been a "hot topic" for many scholars, and remains a complex issue that has yet to be exposed fully. Using critical geopolitics as a base framework can help to expose some of the hidden truths. Additionally it assesses the geographical ways the world is organized, what kind of world is constituted and how it is socially constructed.

The geography of the Global War on Terror in response to $9 / 11$ is central to our understanding of this issue from a geopolitical perspective. Americans, along with the rest of the world, were in such shock on 9/11 that no one had the tools to understand what was happening. How did terrorists from "over there" fly American planes, into American cities, and kill Americans? No one really knew how to react, and Americans were paralyzed with fear at the sudden reality that terrorism can exist in the United States. Terrorism, once a far away and distant notion, had come knocking on America's door. After 9/11, "the assumption that America was immune to terrorism" was not applicable any longer, and "global threats" had impacted America in ways more shocking than anyone could have imagined. (Dalby 2003, p. 67). Dalby explains this further,

"Some of the outrage in New York in particular was apparently because the conventional categories didn't work; the explanatory schemes available to make sense of the events were obviously inadequate. Part of this was because of the sheer scale of the atrocity" (Dalby 2003, p. 69).

A new way of thinking was required to deal with these new type of threats. However, that thinking did not exist yet - and in attempts to react as quickly as possible to what Bush saw as an act of war, America waged war on Afghanistan - a state, although Afghanistan the state did not really attack America. The situation was far more complex, but 
geopolitical categories were not yet in place to deal with such an act of violence. Americans were spatially violated on $9 / 11$. This is something different than we have seen before. There was no "war" when the terrorists attacked, America was not attacked by another state, and suddenly individuals from several nations came together, from "very far away" to kill Americans in the centre of their biggest city. Globalization is more than free trade and friendly relations - globalization means terrorists from half way across the world can commit acts of violence on American soil. Dalby writes about the reaction to 9/11 as being,

"Anger and war combined with the sense of a profound spatial violation of security. The long historical construction of American exceptionalism, of the United States as a moral, virtuous and innocent community in the face of an evil world, was added to the sense of violation to demand retribution and military action" (Dalby 2003, p. 70).

With that, the Global War on Terror was announced. However new this situation was, and however different it was from before, Bush still used "old" thinking to combat something new. He was still thinking in terms of state violence. Attacking terror(ism) is difficult, which is why Bush began by stating America would attack all nations that harbour terrorists. "The geography in this formulation implicitly recognizes the inadequacies of such geopolitical designations. Clearly violence is not constrained to the territories of either of the protagonists" (Dalby 2003, p. 74). Terror doesn't have a territory, or a state - but unable to comprehend this new form of warfare that America was suddenly introduced to, Bush went the old route and tried to fit it into the category of state rivalry, attacking Afghanistan then Iraq in hopes to eradicate terrorism. 
Instead of looking into what caused this attack, Bush oversimplified the situation and made it black and white - "us versus them". Removing all political intentions from the attacks Bush presented $9 / 11$ as an attack on Americans and their freedoms. Dalby explains this here:

"The geography in this scripting of events has little to do with complex diasporic politics, political economies of resource control, power and violence at distances from the metropole. The United States is, in the language of moral exceptionalism, the aggrieved victim rather than a political player in a much bigger and more complex drama" (Dalby 2003, p. 76).

Bush wanted the sympathies of the world in claiming America was an innocent victim, attacked by the evildoers of the world, who essentially despise Americans and their freedoms. America's decision to go to war with Iraq erased any sympathy that the world had for America on 9/11. Not too many were behind America when they went to war, and many critics suspected Imperial ambitions. Changing the spatial understanding of America from a victim of violence and terror to and imperial actor challenges common understandings of $9 / 11$ and exposes "taken-for-granted geopolitical tropes as a political strategy that is both efficacious in mobilizing the population for war and in obscuring the larger patterns of interconnection in the global (imperial?) polity" (Dalby 2003, p. 82). It is clear to say that George W Bush presented America in a very geographically specific way, in intentions to create both concrete boundaries, which for example can be seen in intensified border control; but also metaphorically, America was seen as polar opposite from the terrorists. They (usually in reference to the middle east) were "evil" and America was innocent and only a victim of their behaviour. 
The pre-planned agenda is represented through the right wing think tank the Project for the New American Century (PNAC). Thought to be the brains behind the Bush Doctrine, this think tank has advocated for increased military spending, preserving and advancing America's dominance in the world and advocates pre-eminence as its main military strategy. PNAC had vested interests in American being in a state of exception. They have been advocating for a new world order for years. Not only in the formation of the think tank in 1997, but as we will see, these ideas surfaced several times earlier, before PNAC was even formed, by some of the same members in other positions. Some can be traced back to the first Bush administration, others, much farther back. The historical origins of PNAC will be discussed in more detail in a chapter dedicated to the think tank, however for now it is crucial to note that they represented an "epochal change, the flowering of a new view of America's role in the world" (Mann 2004, p. xii). Mann writes that the "this new worldview represented the culmination of ideas and dreams that had been evolving in Republican administrations for more than three decades" (Mann 2004, p. xii).

A new world order, a new organization of society using war as its organizing force, and unlimited powers is not something that can be implemented or even suggested at random. As the opening quote suggested, something really terrible, yet amazing had to happen for a big change to occur. Keeping America at the top of the world, and simultaneously keeping every other nation inferior to it has several advantages. Not only politically, but economically and socially as well. PNAC wanted to maintain, even enhance America's superiority, while making sure the rest of the world remained inferior, 
ensuring America would emerge as the only superpower. This would allow them to do anything and everything, domestically and internationally, without such organizations as the United Nations getting in the way. It's importance and relevance will be discussed further along in the analysis, and in more detail, clarifying PNAC's goals for a new America.

Post 9/11, geopolitical categories have shifted dramatically. President Bush was one of the first to let the world know about that. Reflecting upon the implications of $9 / 11$, Bush explained how he saw geopolitics to have changed:

"Prior to September the 11th, we were discussing smart sanctions. We were trying to fashion a sanction regime that would make it more likely to be able to contain somebody like Saddam Hussein. After September the 11th, the doctrine of containment just doesn't hold any water, as far as I'm concerned"' (Bush 2003b)

Since this doctrine didn't adequately address the geopolitics of this "new" world, Bush put in place several policies that came to be known as the Bush Doctrine. The Bush Doctrine provided "an overarching conceptualization of how the world is organized, of what America's role in that world is, and how American power is to be understood and used" (Dalby 2006, p. 34). After 9/11, it was elaborated to specifically address the new issues that America faced. The doctrine drew on "existing geopolitical thinking and focused on 'war' as the primary response to what were understood as new 'global' dangers" (lbid). 
In the aftermath of September $11^{\text {th }}$, the GWOT was established and the new strategy, which was essentially the Bush Doctrine, was codified in the 2002 National Security Strategy (NSS) (Dalby 2006, p. 42). The language used in the NSS and by Bush identifies America as a unique state with a unique role in the international community, and in history as a global protector and policeman (Dalby 2006, p. 44). When one looks at the publications by PNAC and compares them to the documents in which the central tenets of the Bush Doctrine are outlined, there is a clear and evident link between the two, which will be explored in detail later.

The most obvious implementation of the Bush Doctrine was in the invasion of Iraq. Iraq was entered unilaterally, pre-emptively and "illegally" as the international community at large and the United Nations did not support the United States. Before the invasion, the administration created geopolitical assumptions about Iraq, the War on Terror and Saddam Hussein using the fears of the American public, repeating how if they do not attack Iraq now, another $9 / 11$ was just a matter of time. Donald Rumsfeld, then Secretary of Defence, explains how the common geopolitical sense was framed and how everything changed after $9 / 11$.

"The coalition did not act in Iraq because we had discovered dramatic new evidence of Iraq's pursuit of weapons of mass destruction. We acted because we saw the evidence in a dramatic new light-through the prism of our experience on 9/11" (Donald Rumsfeld as quoted in Sparke 2007, p. 342). 
This quote provides evidence that $9 / 11$ was the new excuse for everything, even the invasion of a country, which hadn't really been an issue for the past ten years.

A situation has occurred in America opening a "window of opportunity" for the Bush administration to use sympathy and fear in order to constitute new geopolitical categories, and suspend several civil rights (by passing the Patriot Act for example) and infringed on the sovereignty of other states and their citizens (such as Iraq). Combining these infringements with fears of the "other", and framing those in an "axis of evil" creates unreal fears about dangers in the world. Gregory writes about Guantanamo as a space of exception describing it here:

"[It is] a 'lawless place' that is 'beyond the reach of national and international law'; a place where sovereign power has been mobilized 'outside the rule of law'; a wild zone subject to 'a lawless and prerogatory power', where 'the law is effectively suspended in both its national and international forms' and where sovereign power is extended 'in excess of the law'; a 'law-free zone'; and a legal 'black hole'” (Gregory 2006, p. 408).

Gregory's definition will be the primary definition of a state of exception I will use throughout this thesis. The writings of Schmitt, Agamben and Hardt and Negri will be crucial in understanding the theories on states of exception. Following that a critical analysis of the Bush Doctrine, Project for the New American Century, the 9/11 Commission Report and the National Security Strategy and how each sheds light on how this all comes together in the context of America and its transformation into a state of exception will be conducted. 
Much of geopolitical theory is centered on the inevitability of rivalry, and the reality that states are always in competition with one another. The way our world is organized is founded on the principle that states are always in opposition - a realist model of international relations. This being said, $O$ Tuathail asserts that critical geopolitics takes this thinking up a level, beyond political realism. The theory that states, all states are in competition, and just as Hobbes would suggest this is natural, cannot really explain historical instances of cooperation, the most obvious example being the European Union (O Tuathail 2006, p. 6). The other issue with this way of looking at the world, through a "realist" lens is that realists do not recognize their theories to be a set of beliefs; they see the world as "out there" - a truth that they are only bringing to our attention, and not a part of creating (Ibid).

Critical geopolitical analysis (CGA) reveals how the geopolitical categories are made in the first place. For example, the theme of "us versus them" is a prominent one throughout this analysis, and one that Bush tried to create very quickly to gain support for the GWOT. CGA asks questions in order to understand how these categories are created. How did Bush for example, create such a prominent us versus them rhetoric? Post 9/11, the Middle East was seen in an even dimmer light. Geographically, the whole region became "them", while the United States remained "us". One was "evil" and one was "good". Therefore, Bush created and reinforced these geopolitical categories, and CGA looks at historical evidence, motives, intentions and potential outcomes in order to analyze how geography and politics mesh together to shape our world. This thesis argues that America shows characteristics of being in a state of exception, and CGA explores 
why this would be an ideal situation for America, and how accomplished this. Other questions include, what are the possible outcomes of being in a state of exception? How are categories of inside and outside created? CGA is a unique way to study these issues because it questions the taken for granted beliefs, instead of just analyzing them as a "given". Many disciplines, such as political science, will identify strongly with a theory such as realism, and analyze everything from that one perspective. Critical geopolitics looks deeper, and tries to reveal why we think these things are a given, how we got there, and proceeds to analyze issues with a broader view, one not confined to a particular theory, or lens. I will use CGA as a form of answering these questions by critically analyzing several documents and speeches, taking into account historical events that have brought America to the position it is now.

Most people categorize the world geopolitically via taken for granted beliefs. We do not think so much about why "they" are evil. These made-up, and taken for granted beliefs that the Bush administration presented as facts to its own citizen and the international public with, suited its needs perfectly. The Hobbesian account of inherent rivalry, and how some states will always be out to destroy others, the creation homeland security, the fake WMD in Iraq, the "Axis of Evil" and all the other aspects that factor into the logic that the Bush administration led troops into Iraq with, and declared a "Global War on Terror" with. Inherent rivalry means that there has to be a victor. In this case, the United States made sure that would be their title. The state of exception allows military forces both domestically and internationally to shape a context for US dominance, which is what PNAC was striving for. 
All these are reasons why critical geopolitics will be the "lens" through which my thesis will explore the issues of $9 / 11$, terrorism, the Global War on Terror, and the invasion of Iraq. This thesis will attempt to show how the realist assumptions are created, and are not just a given, natural way of life, or an "inherent" condition, but in fact that they are constructed, and therefore deconstructing them is the first step to change. This thesis seeks to explore the War on Terror and states of exception in geographical terms. The new "prism" that Donald Rumsfeld referred to is what provided the excuse for the GWOT and a state of exception. What was different was that everything from then on was seen through the new experiences of 9/11. Like some sort of revelation, Rumsfeld proposed that the geography of danger had changed, boundaries could no longer keep evil off America soil, threats "over there" were now equivalent to the ones "over here" and any action that needed legitimation came from $9 / 11$ and the new geopolitics that were born out of its consequence. As acknowledged earlier, past American administrations have used a variety of excuses to extend their powers. History would suggest that Presidential powers have been on several instances increased during emergency situations, specifically in times of war. However, while this is important to note, this thesis will not be a comparative analysis of those past historical instances to that of 9/11. Themes of imperial ambitions, sovereignty, territory and authority will be explored throughout. Critical geopolitics calls on us to scrutinize, question and analyze the world around us, how it came to be this way, and how to change it for the better. That being said, this thesis presents a critical analysis of American decisions post $9 / 11$ and their aftermath while trying to stay true to the call of critical geopolitics. 
I will begin with different theorists and how they understand states of exception, featuring key authors such as Agamben, Schmitt, Hardt and Negri. These authors have contributed to discussion and development in our theoretical understanding of "the exception" and relatedly, "states of exception". Their contributions will form the basis for the theoretical foundations of this argument. These will be the theorists most often referred to in discussions pertaining to the Global War on Terror. Although they are not geographers, to think of their work geographically is quite appropriate, as questions regarding states of exception and their relevance to the current American situation have been revived. The pertinence of their work in relation to this argument is key. Following this, in Chapter Two, a detailed discussion of key geographers, and how they view states of exception in relation to $9 / 11$ and the war on terror will be presented. This will put the theories of states of exception in context for the purposes of this thesis as they relate to the main research question. It is important to note here, that geographers are not in agreement about how to approach states of exception, matters of sovereignty and authority, or the War on Terror. There is no single view that represents "geography", and therefore this thesis will present several different views, sorting through some of the debate on various issues. Chapter Three will discuss the Project for the New American Century (PNAC), its goals and aims, influences upon the Bush Doctrine and what, how and why their intentions were so influential during the Bush presidency, and specifically after $9 / 11$ as per the war on terror and the invasion of Iraq. The fourth chapter will cover the Bush Doctrine, the National Commission on Terrorist Attacks (9/11 Commission report), the Patriot Act and the National Security Strategy (specifically of 2002). This chapter aims to make links between the above reports, and specifically links them to the 
intentions of PNAC to show the interconnectedness of the key players, documents and reports which not only formed the "Bush Doctrine", but really characterized eight years of Bush's presidency. A clear overlap between the documents PNAC presents, the NSS then solidifies, and the $9 / 11$ commission report then confirms, will be demonstrated. The Fifth chapter will then make the argument of how geographical perceptions of fear after 9/11 were used as an excuse to implement the pre planned agendas of PNAC, under the Bush administration and Bush Doctrine, to transform America into being in a state of exception. Theories on states of exception, coupled with the discussions in previous chapters will be made, leading to the final chapter which is an analysis of the issues, and concludes that in fact America shows signs of being a state of exception post 9/11. The exception represents a change in perspective in America. The geography of danger has changed, and therefore the exception is in reaction to this geographical shift, and not solely to the idea of the attack itself. This geopolitical shift in perspective is what allowed emergency measures to be implemented relatively easily. Additionally, the change in geographical understanding of danger renewed preemption in American foreign policy. Given that these new dangers were everywhere, preemption and preventive war would ensure that threats could be handled before they even materialize. This first chapter will lay down the basis for the theories on exception, followed by a chapter devoted to the geography of the exception. 


\section{CHAPTER 1}

\section{States of Exception: Exploring the Exception(al), Political and (II)legal}

War is a mere continuation of politics by other means - Carl Von Clausewitz

This chapter will begin with Schmitt's theory on the state of exception. A discussion of sovereignty, power and authority will be thoroughly discussed. Following this, Agamben's take on the state of exception, largely in relation to Schmitt's analysis will take place. Agamben is most often cited in reference to theories on states of exception and his discussions will be central throughout the thesis. The theory of necessity will be brought into the analysis in order to better place states of exception into context, especially how it relates to legitimacy, and will prove to be an essential part of the discussion. Finally, Hardt and Negri's theories on the "double exception" will build on the classical conception of Schmitt and Agamben's view on states of exception. Hardt and Negri's theories really complement Agamben and Schmitt, placing the exception and the war on terror in a larger scheme of things. The double exception is central to this thesis and puts the American case into perspective given the Global War on Terror and policy decisions. Geopolitics in the context of this thesis specifically looks at how the shift in geographical perceptions of danger provided the excuse for the exception in the first place. America's double exception has existed for a long time, as seen in previous historical examples. The "right" to go to any lengths to protect America, at any cost, with or without international support, or more specifically the United Nations' support is not a new right post 9/11. However, now that the Bush administration perceived danger to have 
changed, invoking the exception on a more permanent basis was somewhat legitimized. Because of this new type of danger, Bush implied through his actions that the United States could be exempt from the law within the international community (i.e. the United Nations) and the "illegal" war against Iraq. The following will present a basis for the theories on states of exception, and chapter two will provide a geopolitical analysis to complement the theories discussed here.

Schmitt wrote, "sovereign is he who decides on the exception" (Schmitt, 1985, p. 5). Schmitt's concepts of the exception and sovereignty are intertwined; therefore it is necessary to understand one as being part of the other. Theoretical reflection upon states of exception, which were later expanded greatly by Georgio Agamben, begin with Schmitt's main concept on what defines an 'exception' and who can decide on that exception.

According to Schmitt, what constitutes an exception is unlimited authority, which ultimately means the power to suspend the existing order (Schmitt, 1985, p. 12). The exception becomes a reality when there is "a case of extreme peril, a danger to the existence of the state", and other such situations (Schmitt, 1985, p. 6). He is careful to clarify that the suspension of the existing order does not mean anarchy or chaos, because in this situation the state remains, and becomes more powerful as law retreats (Schmitt, 1985, p. 12). Such "extreme" measures should only be taken if the sovereign feels that the state is or may be under attack and therefore it is done only in an act of selfpreservation. 
The sovereign has a conflicting role in a state of exception because he must decide whether there is an emergency and if so, how to eliminate it. So although the sovereign is outside the legal system, he still is a part of it and as such must decide whether or not it is appropriate to suspend the constitution (Schmitt, 1985, p. 7).

There is a paradox in Schmitt's theory. In stating that the sovereign's decision to declare a state of exception (i.e. the quintessence of sovereignty) in its definitive form is the ability to decide first whether a 'normal situation' exists, and furthermore decide if the normal situation must be suspended and a state of emergency declared (Schmitt 1985). "There exists no norm that is applicable to chaos" (Schmitt, 1985, p. 13) writes Schmitt, because in order for legal order to make sense there needs to be a 'normal situation'. Therefore, once the normal situation has ceased to exist and since there is no legal way to handle it, the sovereign can decide what to do should there be a "state of exception". Schmitt argues that the essence of sovereignty is not in the rule, but the right to decide the exception. He writes:

"The rule proves nothing; the exception proves everything: it confirms not only the rule but also its existence, which derives only from the exception. In the exception the power of real life breaks through the crust of a mechanism that has become torpid by repetition" (Schmitt 1985, p. 15).

Bringing this back to Schmitt's concept of sovereignty, based on his argument on the exception and how it is decided, he writes that "therein resides the essence of the state's sovereignty, which must be juristically defined correctly, not as the monopoly to coerce 
or to rule, but as the monopoly to decide" (Schmitt 1985, p. 13). According to him, sovereignty is only really clearly seen when a crisis is about to occur and the transition between a normal state and an exception are about to take place. Only then can the sovereign's role be clearly defined.

Giorgio Agamben defines the exception as he understands it as constituting an imbalance between several things: public law and political fact, a crossroads between the political and legal, and a legal form of what can not really have a legal form (Agamben, 2005, p. 1). Agamben argues against Schmitt's point regarding the paradox of an exception being part of the law and outside the law at the same time. He concludes that a state of exception would essentially be a "no man's land between law and politics, juridical order and life (Ibid). He writes

"If the law employs the exception that is the suspension of law itself - as its original means of referring to and encompassing life, then a theory of the state of exception is the preliminary condition for any definition of the relation that binds and, at the same time, abandons the living being to law"(Agamben 2005, p. 1).

As it abandons the law, he says that Schmitt's theory of a state of exception being grounded in some sort of juridical process is "fallacious" as the state of exception is a space without law and not a "state of law" (Agamben 2005, p. 51). This is one of the key differences in how Agamben and Schmitt define a state of exception. Agamben continues to say it is a space "devoid of law" and "a zone of anomie", and therefore theories that seek to incorporate the state of exception into the law are false (Agamben 2005, p. 50). 
Agamben sees Schmitt's theory on the state of exception being established within the body of law, which cannot be reconciled with the idea of a lawless state, and therefore he argues against this type of characterization.

The key problem with connecting the events that can happen in a state of exception directly to a suspension of law is that they have no legal definition, and therefore have no place in respect to the law. Therefore, Agamben argues that a state of exception is simply a lawless state, where anything goes so to speak, and there is no "law" to make any action illegal, or unconstitutional, as all law and constitution is suspended. Again, he repeats that "the state of necessity is not a "state of law", but a space without law" (Agamben 2005, p. 51).

\section{Necessity}

According to theorists Schmitt and Agamben, necessity is the foundation for the state of exception; and because a state of exception is declared in cases of self preservation of the state, there is no need for a pre-existing order as a reference point to call a state of exception into being because "necessity knows no law" (Schwab 1970, p. 7). Agamben sees two ways in which to interpret this. One is that necessity does not recognize any type of law, and the other is that necessity creates its own law (Agamben 2005 , p. 24). "The theory of necessity is non other than a theory of the exception by virtue of which a particular case is released from the obligation to observe the law", writes Agamben (2005, p. 25). Necessity is not a part of the law, and neither does it 
observe the law. It is a situation in which "it merely releases a particular case from the literal application of the norm" (Ibid). The state of exception only acts as a law, because like laws, which are created and applied for the well being of citizens, the state of exception, derived from necessity is implemented (in theory) for the well being of citizens (Ibid). Who decides what constitutes necessity and what measures are taken is entirely subjective, and therefore leaves room for abuse of power.

What the state of exception is, is not entirely clear as it exists in a grey zone, where it is not part of the juridical order, and can be seen as a lawless state, however it does not mean that the suspension of laws are permanent. However, when powers to suspend the law go too far, and a somewhat "permanent state of exception" develops (when the state is no longer under attack, or does not need extreme measures of self preservation to be taken) then, an abuse of power can be argued.

Post 9/11, Agamben argues that President Bush's constant references to himself as the "commander in chief of the Army" reiterates his presidential claim to sovereign powers in emergency situations (Agamben 2005, p. 22). Agamben sees this as a direct reference to the state of exception, and abuse of power as Bush is attempting to produce a situation in which the emergency becomes the rule - a very dangerous place for human and civil rights (Ibid). 


\section{Double Exception: How the Double Standard is Legitimized}

"If we have to use force, it is because we are America. We are the indispensable nation" Madeleine Albright (Hardt and Negri 2004, p. 8).

Hardt and Negri introduce the concept of the "double exception" for America. This is the state of exception that has already been discussed by Agamben and Schmitt, which they say is the real basis of the state of exception. This is in reference to a state of emergency, such as during $9 / 11$, when the sovereign has the right to stand above the law and take control. Hardt and Negri emphasize this has nothing to do with morals or right; only to do with might (Hardt and Negri 2004, p. 9). The second type of exception they discuss is the exceptionalism of the United States. As the world's only remaining superpower, Hardt and Negri argue that the key to understanding the global war taking place now lies at the intersection between these two exceptions (Hardt and Negri 2004, p. 8).

To elaborate more on the second type of exception, the exceptionalism of the United States, Hardt and Negri explain this concept lies in two different and incompatible meanings. The first is America's claim to be an exception from the corruption of the European sovereignty and, by contrast, a "beacon" republican virtue. It can be seen today in the claim that the United States makes about being responsible for promoting and protecting global democracy, human rights, and the international rule of law (Hardt and Negri 2004, p. 8). The second meaning to US exceptionalism is an exception from the law. In recent history, the United States has exempt itself from international agreements 
like Kyoto, other environmental, human rights and criminal court agreements as well. Additionally, Hardt and Negri point out that the US claims its military does not have to obey the rules others are required to obey such as preemptive strikes, weapons control, and illegal detention (Ibid). This will be explored later, however it is important to note that the U.S. feels it is their right to behave in this way because of their exceptionalism.

It is clear then, that there is contradiction in the two meanings. For example, how can America be 'responsible' for protecting and promoting democracy and international law, and at the same time exempt itself when it feels it necessary from international agreements? The answer to "how" if one were to ask G.W. Bush, or perhaps Madeleine Albright, is, because it can. It is that simple. The double exception is essentially a double standard. As the world's only remaining superpower, the double standard has been intensified. Hardt and Negri argue that this type of a double standard is the basis of tyranny and makes it impossible for a healthy democracy based on freedom and equality to truly exist (Hardt and Negri 2004, p. 9).

Hardt and Negri also argue that President Bush abused powers post 9/11 in declaring a state of emergency that became permanent. They write, "today the possibility of democracy is obscured and threatened by the seemingly permanent state of conflict across the world" (Hardt and Negri 2004, p. xi). They warn that democracy and war are incompatible and the current situation not only poses a threat to democracy in the United States but also to 'global democracy' and peace. In past times of war, states of emergency have been called, giving power to an elite group. This is not necessarily new, however in 
what they call an "era of armed globalization" and an endless war, the suspension of democracy (much like the state of emergency) seems to have become permanent (Hardt and Negri 2004, p. xii).

The post 9/11 world under the Bush administration has taken backward steps in peace and democracy, argue Hardt and Negri. It seems that these steps have led us back to a time when war is endless and continuous, where international law is suspended or does not exist, and where there is no definite distinction between acts of war and peace. They conclude that the current state of the world has driven nations apart and created a dangerous situation for peace and international diplomacy: "the state of exception has become the rule, pervading both foreign relations and the homeland" (Hardt and Negri 2004, p. 7).

War has become a permanent social relation and organizing principle in today's society (Hardt and Negri 2004, p. 12). Clausewitz said that war is a continuation of politics by other means, but today, Hardt and Negri argue, it may be that politics is becoming war conducted by other means; politics becomes a means of war (Ibid). "War has become the general matrix for all relations of power and techniques of domination, whether or not bloodshed is involved" (Hardt and Negri 2004, p. 13). War has become what Hardt and Negri refer to as a "regime of biopower", a form of rule that produces and reproduces all aspects of social life (Ibid). They argue that it is the metaphorical discourse of war that is a strategy in politics, which aims to achieve a mobilization and unity of social forces, similar to how war brings a nation together for a common goal. An 
example of this was the "war on poverty" in the United States during the 1960s. It used the discourse of war to promote national unity to gain social support for domestic policies. However, "poverty" is an abstract enemy, it does not have a territory or hideout to bomb, making it endless, and making it 'everywhere' - it is non violent, but it is enough to keep referring to it to rally social forces in favour of policies for example (Hardt and Negri 2004, p. 13). This is exactly how the "War on Terror" works. It is totally abstract, and meant to create a public enemy, an "other" that can be used to mobilize the nation towards a unitary goal.

Like the War on Poverty, the War on Terror is also never ending. It is not possible to declare war on an ideology (or a means to an end, which is often what terrorism is) and "win". It is impossible to kill an ideology, or to control everyone who chooses to use terror as a means. At least not with a specified amount of money and troops the way that America dedicated a "budget" to the War on Terror. "When US leaders announced the war against terrorism they emphasized that it would have to extend throughout the world and continue for an indefinite period, perhaps decades or even generations" (Hardt and Negri 2004, p. 14). It seems convenient when we consider that the war was launched to create and maintain a certain social order. Because it can have no end, it must involve the "continuous, uninterrupted exercise of power and violence" (Ibid). Due to the continuity of the war, it becomes almost impossible to distinguish it from police activity, especially when such emergency measures like the Patriot Act are being renewed, even after the immediate threat of terrorist attacks are over (Ibid). 
"When crisis is no longer limited and specific but becomes a general omni-crisis, when the state of war and thus the state of exception become indefinite or even permanent, as they do today, then contradiction is fully expressed and the concept takes on an entirely different character" (Hardt and Negri 2004, p. 8).

This is what has happened with the current state of affairs in the United States. The immediate threat has been removed, but a "war" is on going. Whenever the Bush administration needed legitimacy for its actions, reference is always made to the "War on Terror". Constant references to how America can be attacked anywhere at anytime perpetuates the fear that keeps the nation in a state of emergency - even if the emergency is not present.

"Our challenge in this new century is a difficult one; to defend our nation against the unknown, the uncertain, the unseen, and the unexpected" (Donald Rumsfeld as cited in Hardt and Negri 2004, p. 36).

Keeping a society in a constant state of panic, fear and wartime attitude is not easy. A lot of planning was put in by the Bush administration into making the "War on Terror" something concrete that citizens could be afraid of, and make them willing to give up some of their civil rights in exchange for their "safety". A lot of propaganda was created by the Bush administration to sell a never-ending war to American citizens. Post 9/11, Osama Bin Laden could not be found, and therefore Afghanistan and more importantly Iraq created distractions and justifications for the continuation of this neverending War on Terror. The concept of "just war" was re-introduced into political discourse in the United States. 
"The concept of justice serves to universalize war beyond any particular interests toward the interest of humanity as a whole. Justice tends to generalize war beyond its proper scope and confuse it with other social realms, such as morality and religion" (Hardt and Negri 2004, p. 15).

Soon enough, Americans were confused. Who really was the bad guy - Saddam Hussein or Osama Bin Laden? Going into Iraq, via just war doctrines created a "real" war for America to fight and because the nation was at war, freedoms could continue to be compromised for homeland security.

Just war doctrine is tricky because it entirely depends on who defines what is just. The three main principles of Just War theory are legitimacy, proportionality and responsibility (Moseley 2009). Legitimacy is in reference to who are legitimate targets in war. It is also about when is it legitimate to attack and who is it legitimate to attack (Moseley 2009). Proportionality concerns how much force is "morally appropriate", and responsibility is in reference to where the responsibility lies in war (Moseley 2009). Although civilians are almost never "intentionally" harmed, the terrorists for example are legitimate targets. Furthermore, if a lot of force is justified for this (example: the "shock and awe" campaign in Iraq in 2003), and therefore if civilians are killed in the process, that may also be justified. Again, the issue is who can legitimize a war in general, or even legitimize a war as a “just war"? The justness of just war operates on two separate levels. One is the justness of the cause, i.e. is it winnable? Second, is the justness of the resort are the means just? If legitimacy is in the hands of the sovereign, according to Schmitt and others, then a sovereign could legitimize any war if he is the sole decider. However, 
he does not need to justify anything for he is the sovereign. Bellamy cites Vitoria in his piece on just war and writes,

"The sovereign's belief alone did not constitute grounds for war. Rather, a sovereign was required consult as widely as possible with good and wise men, and must listen to the counsel of those who oppose war. Failure to do so could render the sovereign morally liable for their unjustified war" (Bellamy 2009, p. 241).

One of the main reasons that entering Iraq was seen as illegitimate was because the international community at large, and the United Nations did not approve the war, and did not support American troops going into Iraq.

A never-ending war against terror was an excuse to keep America in a permanent state of exception. Defending the homeland was not the sole or central reason to go into Iraq. Just war doctrine and fighting terrorism was just a distraction. The real purpose was total social control and world dominance - a major step to thrusting the United States to permanent world leader status. This is something that couldn't have been done as "smoothly" without the tragedies of 9/11. Since 2001, America has experienced "diminishing civil liberties and increasing rates of incarceration" which according to Hardt and Negri are a "manifestation of a constant social war" (Hardt and Negri 2004, p. 17). Traditionally, the wartime suspension of democratic principles was temporary, and only under exceptional circumstances. Post 9/11 in America, the state of war has become a "permanent global condition", where the suspension of democratic politics has gone on far beyond "necessity" and has taken on a whole other character (Ibid). "Like justice, democracy does not belong to war" (Ibid). When war is no longer part of a state of 
exception or an exceptional condition, it becomes normalized and a perpetual state of war is produced. Thus, instead of war being a destabilizing force, it becomes a tool for reinforcing the current global order (Hardt and Negri 2004, p. 21). "The constant presence of an enemy and the threat of disorder are necessary in order to legitimate imperial violence" write Hardt and Negri (2004, p. 30). The enemy has become abstract, it is unknown and unseen and yet ever present, just as Rumsfeld describes in his above quote. The most important role of the enemy is that it "serves to prop up legitimation where legitimation has declined". (Hardt and Negri 2004, p. 30).

If war is no longer an exceptional condition but the normal state of affairs, then we have now entered a perpetual state of war. It becomes necessary that war not be a threat to the existing structure of power, not a destabilizing force, but rather, on the contrary, an active mechanism that constantly creates and reinforces the present global order (Hardt and Negri 2004, p. 21). War always necessitates the partial or total suspension of democratic principles. "In wartime, the democratic principle has to yield to a strictly autocratic one: everyone must pay unconditional obedience to the leader" says Hans Kelsen (Hardt and Negri 2004, p. 17). This is where Schmitt's sovereign comes back into play. He will decide the exception and therefore suspend the law.

The new war brought about by $9 / 11$, had a policy focus on "security" instead of "defense" - something the Bush administration really tried to promote in the weeks and months after September $11^{\text {th }}$ (Hardt and Negri 2004, p. 20). This meant a change from a conservative reactive attitude to a proactive one in regards to both national boundaries and a move from preserving the current status quo when it comes to social and political 
order to transforming it (Ibid). This transformation also includes moving from a "reactive war attitude, which responds to external attacks, to an active attitude that aims to preempt attack", one of the main principles of the Bush Doctrine to be explored later (Ibid). The notion of security versus that of defense "signals a lack of distinction between inside and outside, between the military and the police" (Hardt and Negri 2004, p. 21). Defense implies a more protective aspect against threats to the nation, whereas security implies and justifies constant martial activity both in the United States and abroad (Ibid).

All this language is affiliated with war. In fact, George W. Bush identifies himself with war in general, and especially as he campaigned as being a "war time President" and "Commander in Chief" more than he did as a representative of the people. Using this kind of language, and calling it a "war" on terror was strategic on Bush's part for several reasons. War creates clear distinctions in people's minds about us versus them. It is one of the easiest ways to "other" another nation, culture, person, etc. Because of this distinction between us and them, it also allows everyone to rally together, and be on one side, the way that all Americans were on September $11^{\text {th }}$. Right after the attacks, no one was Democratic or Republican, but they were Americans all hurting together. Bush tried to carry on this collective attitude, and although there were many groups against the Iraq war, everyone was pretty much behind the new "War on Terror". So by declaring it a war, just like the "war on poverty" or "war on drugs" and other similar notions, the War on Terror was an effort to get everyone on one side; the American side. 
Additional to these reasons, war is also a way to organize society that allows for a lot more control. During wartime, it is not unusual that laws are suspended, and certain rights and freedoms also affected. The "War on terror" is a never-ending war, not one that can necessarily be won, and knowing this the Bush administration intentionally used this abstract and vague title. Organizing the society, and controlling the society in a perpetual state of war was one of the main goals of PNAC as well, and again will be explored in more depth later. Finally, another reason for why it is a "war" on terror is that Bush follows a Hobbesian view of nature, similar to the one discussed before. One that presents the world as competing rival states, and war is seen as something natural and inevitable. It also allows America to act as the international savior, ridding the world of terror by declaring a war against it. Again, as PNAC had advocated, this type of a scenario would put America in place to demonstrate global leadership.

Bush also believes, like many before him, that it is America's "manifest destiny" to protect the world, and often attributes violence (even presently) to a violent past. Blomley cites Kenneth Foote's argument that violence has always been central to American national identity, and traces it as far back to its violent colonial settlement (Blomley 2003, p. 126). He argues that violence is foundational to America's beginnings, and regardless of whether violence is illegal or legal; it has become almost commonplace in American history (Blomley 2003, p. 126). This rhetoric can be seen in much of what Bush proposes in regards to why America was attacked on $9 / 11$, when he has said on several occasions that America will always have enemies that seek to destroy their way of life, and the only way to fight back is with violence. 
Blomley's important argument is in regards to the relationship between law, violence and geography, as he argues, "an attention to violence is incomplete without a critical geographic imaginary" (Blomley 2003, p. 123). He writes,

"Space gets produced, invoked, pulverized, marked, and differentiated through practical and discursive forms of legal violence. And property's violence is itself instantiated and legitimized, yet also complicated and contradicted in and through such spaces" (Blomley 2003, p. 135).

Space is a geographical factor, and therefore violence within these spaces should also be looked at through a critical geopolitics understanding. Blomley's criticism of liberals and their views in regards to violence and law is mainly that they see violence as something outside the law, and outside the state (Blomley 2003, p. 121). In fact, much of the violence today is actually state violence - violence that is on some grounds "legal" or legitimized by states themselves. Blomley points out that violence has a geography and is important, because as he says "space matters to violence", and part of our understanding of war and violence would benefit greatly from more geographical analysis than is immediately in front of us. As it relates to the exception and the creation of "us" versus "them" categories, Blomley asserts, "territorial imagery and constructions of "inside" and "outside" are put to work to justify violence, whether of the state or of paramilitary organizations" (Blomley 2003, p. 123). For example, prison is a geographical space. The prisons of Guantanamo and Abu Ghraib are prime examples of how violence is legitimized against "them" (the detainees) to protect "us" (citizens of America/the world). Blomley's argument should be kept in the back of our minds, as a reminder of the 
geographical importance of violence and law, as we move forth in this analysis.

These authors form the basis of discussion on the theory of exception that will be used throughout the analysis. The primary debate still stands, is the state of exception a part of the law or outside the law itself? How do other authors see necessity and the state of exception, especially as it pertains to the GWOT and events in the United States (and worldwide) post 9/11? The next chapter will discuss the views of several of the key geographers who have written about America, 9/11 the Global War on Terror, the Bush Doctrine and how they understand how this relates to a state of exception. Through a secondary take on the theories of exception and how it relates to the current geopolitical climate, it will bring us one step closer to an understanding of how September $11^{\text {th }}$ was used as a window of opportunity for sweeping political change. 


\section{CHAPTER 2}

\section{States of Exception: A Geopolitical Analysis}

Since Agamben, Schmitt, and Hardt and Negri, many others have theorized on what the recent political changes have meant for America. The implications are felt politically, socially, economically, and personally. States of exception are seen in many different ways. One of them being spaces of exception, like Guantanamo prison, or the prisons in Iraq such as Abu Ghraib. In the following section the thoughts of other geographers on states of exception and America's post 9/11 politics will be reviewed. From the ideas of sovereignty to geopolitical fears, these authors have helped shed light on the theories of states of exception and how they apply to America, specifically how they pertain to the GWOT. These authors were chosen for this section because they are representative of theories relating to critical geopolitics. They represent diverse viewpoints, and all employ interdisciplinary ways of analyzing the geography of danger, $9 / 11$, fears, issues of security and states of exception. Not only do they think outside the box, but these authors draw attention to many important aspects of the war on terror, and states of exception that are either missed by many authors, not covered by the mainstream media, or have been hidden amongst the propaganda surrounding 9/11. Some attention is also given to how the media perpetuated certain views of the war on terrorism and danger, and how that affected American opinions on the issue. The definition of a state of exception that I will be referring to throughout the thesis is one which I have outlined by Agamben and Gregory in the introduction, supplemented heavily by the views of Hardt and Negri. 
Since 9/11, "security" has been put front and centre again, and has become a buzzword both in politics and in academics. During this time when security has an increased importance in contemporary politics, Williams writes that analysis and investigation into its implications are needed now more then ever, especially given that the "politics of emergency" have become rather permanent as well (Williams 2003, p. 529). To look further into this, it is best to look at the basis of Schmitt's idea into the state of exception, which is sovereignty ("sovereign is he who decides on the exception") (Schmitt, 1985, p. 5). Sovereignty is an extremely contested area of study. Theorists have conflicting views on what sovereignty is, how it is defined and how it is administered. Arguments involving international law, the responsibility to protect, and other such issues have been mixed in with debates on sovereignty.

John Agnew presents an alternate way to look at sovereignty, in what he calls "regimes of sovereignty" (Agnew 2005). In this context, he refers to "regimes" as systems of rule, not just an international protocol or agreement between states (Agnew 2005, p. 437). Given this, Agnew argues, "states participate in sovereignty regimes that exhibit distinctive combinations of central state authority and political territoriality" (Ibid). He concludes that "sovereignty is neither inherently territorial nor is it exclusively organized on a state-by-state basis", and therefore, it is not so clear who has full control over sovereignty contrary to what some theorists, such as Schmitt would propose (Ibid). What Agnew is asserting is that in actual practice, sovereignty is not so neatly territorialized, as some would suggest. Generally, the concept of territoriality would imply the use of territory for political, social and economic ends as a means of 
establishing exclusive jurisdiction by a state (Ibid). What this means is that strict territorial boundaries do not always define who has sovereignty within them. Agnew proposes, "negotiation and redefinition of political authority in geographically complex ways suggests the need to change the terms of debate about sovereignty" (Agnew 2005, p. 438).

One of the most controversial aspects in the sovereignty debate is who legitimizes it. Sovereignty has an external dimension, argues Agnew. In order for a state to be legitimized as a sovereign entity, other states must recognize it as such (Agnew 2005, p. 439). This recognition suggests equality between states, in which "none can exercise command over others" "(Ibid). Although a formal agreement may exist in that no state is to interfere into the domestic and internal affairs of another, history presents contrary evidence. Under various headings such as responsibility to protect, humanitarian intervention, and preventive war, the sovereignty of nation-states has been compromised. On this point Dalby writes,

"The return of the theme of empire into political discourse also heightens the need to reflect critically on political spatialities, not least because the military dimensions of current events are so much more obviously about lines in the sand and the possibilities of "interventions," whether military or driven by human security agendas and the "responsibility to protect" (Dalby 2005b, p. 416).

"Juridical" or legal sovereignty provides the "geographical condition for the operation of domestic sovereignty", which is a clear distinction between who has control over the

\footnotetext{
${ }^{1}$ All Members shall refrain in their international relations from the threat or use of force against the territorial integrity or political independence of any state, or in any other manner inconsistent with the Purposes of the United Nations (United Nations 2010, Article 2(4)).
} 
state of the internal affairs of that state, as compared to the territory outside it (Agnew 2005, p. 439). This is the most common understanding of state sovereignty - as an absolute territorial organization of political authority (Ibid).

Theorists like to argue their different theories to be fact, however in the real world, or at least in today's world, inequalities between states exist, within regions and between regions. Agnew writes that "much of this inequality is the result of imperialism in the past and the hegemony exercised by the U.S. and its allies in the present" (Agnew 2005 , p. 441). In much of the world there exists a "sovereignty deficit", where the sovereignty of these states hasn't been realized; they do not have the power resources to challenge restrictions imposed on them by other more powerful states (Ibid). The war in Iraq is a prime example. Iraq did not have resources militarily, or power, internationally, to defend themselves against an invasion. One of many reasons presented was to save the people of Iraq from a terrible leader. That is clearly an internal and domestic affair, and how a country is governed within its "walls" shouldn't be a concern for outside nations. If it does become a concern for outside nations, and humanitarian intervention is an option, usually the majority of the international community is on board, and it becomes a multilateral, unified effort. Agnew argues however, that there are different forms of society apart from the traditional one here.

The key point, says Agnew, is that political authority is not confined to states and such authority is therefore not exclusively territorial, as authority is just the legitimate exercise of power (Agnew 2005, p. 439). Agnew asserts that authority is vested in those 
who manage "flows through space or through action at a distance as much as in those who manage territories" (Agnew 2005, p. 442). "The spatiality of authority, therefore, cannot be entirely reduced to the territorial template of state sovereignty" (Ibid). Therefore, the orthodox conception of sovereignty cannot be applied to today's world given the different levels of power ranging from local to national to international. This is why Agnew proposes sovereignty regimes, which are more encompassing and flexible, and perhaps more realistic then our traditional notions of sovereignty.

In a follow up of his 2005 article, Agnew in his 2009 book Globalization and Sovereignty, argues that "the fields of control and authority associated with sovereignty have never been either monopolized by states or entirely territorial in their application" (Agnew 2009, p. 210). This being said, it is clear that Agnew contrasts with Agamben's views on this matter. Agamben holds the view that territory is central to the definition of the state (Ibid). In what Agnew sees as an exaggeration, Agamben claims that citizens are all prisoners in large camps, perhaps a metaphor to the state itself, instead of active agents who can provoke change (Ibid). Agnew's criticism of this specific point stems from Agamben's views that the exception has become the rule everywhere. He thinks Agamben's direct generalization of the camp sites to larger spaces of exception are problematic due to the fact that something very complex is being oversimplified, and sometimes made even more narrow when assessed as a case study (Agnew 2009, p. 205).

In relation to the exception in specific, Agnew criticizes Schmitt and Agamben for trying to fit sovereignty neatly into the territory container. He writes, "sovereignty of the 
state puts the very life of people in doubt, depending on their biopolitical classification" (Agnew 2009, p. 210). The exception as a territorial confinement means that the sovereign can decide who is inside and outside, and promotes an "us against them" rhetoric, that is evident with President Bush. Furthermore, Agnew argues that Agamben's analysis of the camp does not explain the political structures of the exception and how they relate to military action, borders and international law (Ibid). However, with a "world of flows" replacing a "world of places", the first response is usually to look for a territorial solution (Agnew 2009, p. 211). This may prove to be problematic in a globalized world, and in a post 9/11 world as

"Conventional approaches to territorialize politics to the extent that the social sciences as a whole have totally neglected the roles of spatial interaction and of place-making in everyday politics" (Agnew 2009, p. 206).

More attention needs to be paid to the geography of the War on Terror, and a break from the strict notions of territory and sovereignty is needed, especially when it comes to such a large-scale operation.

Although sovereignty is a considerable area of debate, there are many other aspects pertaining to states of exception and the War on Terror that also deserve attention. One of the most significant changes in government after $9 / 11$ was the creation of a Homeland Security department within the federal government. It seemed that after $9 / 11$, more and more emergency situations kept popping up. In turn more reasons are found for declaring "emergencies" and therefore the situation becomes normalized, but in fact it is not normal at all. There exists a colour-coded fear system (Homeland Security Advisory System), 
which post $9 / 11$ after its creation, was going off in every direction. Orange, then yellow, then red, back to orange, and so on. There was always something to be afraid of that would render an emergency legitimate. The continuous claims to emergencies keep America in a constant state of emergency, and therefore a permanent state of exception develops.

On the topic of homeland security, it is interesting to note why it was created, as there is already a National Security Agency in place. Where as national security was once used to express a states safety, it seems that in a time where dangers are more "global" in nature, "homeland security" is the term of choice (Dalby 2005b, p. 416). As members of the Bush administration have expressed, and as several documents will confirm, the whole world is seen as the homeland, so national security seems territorially limited. It is an intentional change in wording that in attempts to capture the new post $9 / 11$ world of terror. Dalby writes,

"The adoption of the term homeland security is an interesting further indication that an imperial geography of overseas responsibilities is part of the task for US forces; clearly, they now do much more than protect national borders" (Dalby 2005b, p. 416).

Imperial ambitions will be discussed further on in this thesis, however it is important to note the use of language post $9 / 11$ and how it effects our perceptions of our world, danger and threat, and of America's role in it. It is assumed that this language is intentional in forming and solidifying those views. Commenting on the new use of terminology, Dalby says that 
"It apparently needs a new geographical terminology to specify security in the center of what is now implicitly understood as a larger imperial arrangement of power, military operations, and influence" (Dalby 2005b, p. 422).

The state of exception has given way to many things that would otherwise seem absurd, and at the time were, and still are accepted as quite normal. After the passing of the Homeland Security Act, the state of exception "no longer referred to an external state of factual danger and was instead identified with the juridical-political order itself" (Pease 2003). The geographical perceptions had changed, as is evident in the language that was being introduced, while old geopolitical categories were being remade, and new ones were being added.

Gregory is seen as an expert on states of exception as they particularly pertain to the campsites. As a geographer, he has written extensively on the camp, and spaces and states of exception alike. Gregory follows Agamben's thought that in today's world, the exception has become the rule, and reminds us that Benjamin had said the "state of emergency in which we live is not the exception but the rule" (Gregory 2006, p.406). Gregory writes about the state of exception in the context of a post $9 / 11$ world, which proves to be particularly useful to this analysis. Three days after the terrorist attacks on the Pentagon and the World Trade Center on 11 September 2001, President Bush declared a National Emergency "by reason of [those] attacks and the continuing and immediate threat of further attacks on the United States" (Gregory 2006, p.407). This was then followed by further measures to be taken on 23 September 2001 to deal with 
“The unusual and extraordinary threat to the national security, foreign policy and economy of the United States' by 'grave acts of terrorism and threats of terrorism committed by foreign terrorists"'(Gregory 2006, p.407).

Since then, the "emergency" has been renewed every year. Gregory and Agamben suggest that Bush "is attempting to produce a situation in which the emergency becomes the rule': in which 'provisional and exceptional measures' are transformed into 'a technique of government" (Ibid).

What drew Agamben to write about these emergencies as something unique is their proximity and timing as all this happened post $9 / 11$, during a new type of "war", the "War on Terror" (Ibid). Gregory claims that

"The 'war on terror' has accentuated the political and juridical folds between the national and the transnational, but this process was underway long before $9 / 11$, and the relations between sovereign power, law and spatiality have been complicated.." (Gregory 2006, p.407).

Technically, here Gregory is referring to the camp, and Guantanamo Bay, but the same complications Gregory observed are apparent within some areas of America as a nation state. Sovereignty became an increasingly controversial topic around the time when Iraq was presented as a threat, and one that needed to be handled immediately. Law had become so complicated, that in a state of exception it is impossible to tell what is legal and what is not. If it is the law that there is no law, than what does that mean for constitutional rights? Gregory's explanation of law and sovereignty in specific being complicated is also applicable to some aspects of America as a nation state, as it is to his smaller example of Guantanamo. This does not necessarily mean that the example of 
Guantanamo Bay can be directly juxtaposed onto America. Americans are not reduced to bare life, and are not being held in prison cells, however, there are many similarities regarding the rule of (or lack of) law, as well as debates surrounding sovereignty that may be applicable to America post $9 / 11$ specifically. America is still a bureaucracy, and everyday life is still governed by law, but it is the idea that should it be necessary, or convenient (depending on the situation) the government has the legitimacy to suspend those laws. It is more so the theory behind that idea that, if deemed necessary, the laws, rights and freedoms that structure American society can be taken away.

Furthermore, the Bush administration has revived the "doctrine of the unitary executive", in which Bush as commander-in-chief is beyond the law. Gregory asserts

"This perverse reading of the Constitution holds that the executive can override both the judiciary and the legislature. As the profoundly conservative jurist-cum-philosopher Carl Schmitt had it, 'Sovereign is he who decides the exception': and Bush has insisted that he is 'the decider"' (Gregory 2006, p.408).

"National emergencies", writes Gregory, "and the special powers that derive from their proclamation cannot be reduced to decisionism" (Gregory 2006, p.408). The entire juridical process cannot become suddenly irrelevant at the words of any commander in chief and regardless of any type of emergency. Gregory quotes Amy Bartholomew as arguing that "a succession of legal challenges in US courts has shown that "law will not willingly abdicate its role to a state of exception and will continue to act as an obstacle to the arbitrary authority of the executive branch"' (Gregory 2006, p.408). However, if this is the case, then why is it possible for laws to be suspended, and for constitutional rights 
be taken away, such as those in the PATRIOT Act? Laws do present an obstacle to total control and at the same time to total chaos, but in special cases, such as emergencies and states of exception, technically, the right of the President remains that he may suspend any and all laws should he find it necessary. America is an example of this very scenario. There are an array of laws always present, but the ones that are seen as an obstacle to what the government is trying to accomplish, like detention for "no reason", may be changed, suspended or taken away all together.

In this context, we must also consider what this means for "international law". Is international law even something that can be enforced? Besides the United Nations, which is a voluntary association, how can international laws- even those passed by the U.N. - be upheld? Furthermore, if these laws are broken, what is the punishment for breaking them? All these questions are ever more pressing post $9 / 11$, and really make us question what the point is of having something called international law in the first place. Gregory quotes John Austin regarding this matter: "international law is not really law at all: laws could only be 'properly so called' if they were 'commands of a sovereign', which made international law merely "law by close analogy"' (Gregory 2006, p.408). This is an excellent point. However, Gregory argues that the

"Bush administration would clearly like to have the United States regarded as the global sovereign, and it has repeatedly announced that its prosecution of the 'war on terror' will not be hamstrung by what it views as outmoded legal protocols" (Gregory 2006, p.408).

Many critics of the Bush administration have said that Bush \& Co. are waging 'a war on law', referring to both domestically and internationally it seems, in which Bush 
responded "“International law? I'd better call my lawyer. I don't know what you're talking about by international law"' (George Bush as cited in Gregory 2006, p.408). Whether that statement was ignorance or arrogance, it is pretty clear that the administration at the time and even times before it, have no regard for "international law" when it becomes an obstacle to American conquests and interests, but it seems they are suddenly aware of it when it comes to sanctioning and punishing other nations. And of course at times, America does abide by international law. It is on a case-by-case scenario. If it benefits them, whether that be because of a certain image they are trying to portray, or because it fits in with their own policy objectives, they will participate. If not, there is a reason that they somehow can justify, in often cases by using Hardt and Negri's concept of America the "exceptional". This is not something new, and criticisms of American administrations past and present have touched on this issue. The Bush administration, and previous American administrations have always argued that it is America's responsibility to preserve world peace, a duty that has fallen upon them, as they are an exceptional nation, as Hardt and Negri would suggest.

Following Hardt and Negri's analysis, specifically on the double exception, it is clear to see how that double exception played out during the Bush years. Through the creation of a perpetual war, a perpetual state of exception via the war on terror, the U.S. has declared itself the global sovereign. Because the United States is in a state of exception, and sees itself as an exceptional state. The American administration not only suspended laws in its own territory, but also suspended its participation in international law. By doing this, they have created a whole new legal order. They are doing this by 
obeying international laws when beneficial to themselves, and breaking them when they are not. It sets a terrible example for other nations, who in the past have looked up to the United States as an example of a great democracy. It also devalues international law itself as other nations can do the same thing by simply saying that they will not be subject to the double standards of one nation. If they preach to other nations around the world about the importance of following international law, and they haven't led by example, it will be difficult to enforce it upon others; it creates an unfair system. Additional to that it creates hostilities with other nations as they see it unfair that when they see fit the law doesn't apply to them, but as the world's only superpower, they have considerable power over those nations who "break" international law. That power may come in the form of the weight they carry in the UN to sway votes in terms of sanctions and such, or personal relations between America and that nation, such as restricting trades, for example. Many will say this is a new form of Imperialism, and as the world's only remaining superpower, this Imperialism has reached new heights.

The United Nations made it clear that they were against an invasion in Iraq, and through consensus from other nations, they decided it would be "illegal" for the U.S. to proceed with a war. Additionally Kofi Annan stated, "I hope we do not see another Iraqtype operation for a long time - without UN approval and much broader support from the international community" (BBC News, 16/09/04). However, when the Bush administration decided to go ahead anyways, they broke that law. When all was said and done, the United States came back to the United Nations and said they would like assistance in nation building, and cleaning up the mess that they created. They requested 
that the entire international community be on board with rebuilding a nation that they destroyed. Essentially, they took on role of leader of the world, suspended laws, invaded Iraq, then went back to the same international community they brushed aside and restored the international order again, requesting that everyone pitch in to help this nation.

Elden, in his book Terror and Territory extensively covers the War on Terror, states of exception and what it all means for territory. Beginning with what he sees as Agamben's downfall he writes that "what is crucial to remember is that Agamben's point is both historically focused and geographically bounded", too much of his analysis is placed on the camp as a space of exception and creates a narrow view (Elden 2009, p. 57). It is too narrow to generalize the operation of the exception, from the extreme case of the camps. This is a main criticism of Agamben, one that many geographers have picked up on. In order to broaden this narrow view, Elden says we must "introduce both historical and geographical specificity into any extension to other spaces" (Elden 2009, p. 57). Additionally, each case must be analyzed separately, as Elden suggests, because Agamben has focused on a specific camp that he finds to be important for him, and the risk of exaggerating some characteristics exists (Ibid). Given this point of view, Elden argues that political geographers have been "too willing to suggest a generalized model of Agamben's "space of exception"” (Ibid). He asserts that in using a theoretical model, it is important to analyze carefully the specific situation to determine if it is applicable to a larger framework. However, Agamben notes that although the camp is his primary example, it is not the only space of exception. Agamben's theories can be expanded and related to bigger "spaces" of exception, like states, which many theorists have already 
covered. It is also applicable to smaller examples as well such as CIA black cites, supermax prisons, and other examples.

Elden presents another critique of Agamben, pointing out that the territorial and the biopolitical exist, and must therefore be analyzed, together (Elden 2009, p. 57). More specifically, Elden questions if one should ask if Agamben's failure to provide a clear account of the state illustrates a greater weakness in addressing the relation of sovereignty to territory (Ibid). As many theorists have argued, there is nothing that exceptional about "states of exception" anymore as it is now standard for many states to operate all the time as they are in emergency situations (Elden 2009, p. 59). Or maybe it is that emergency situations are falsely created, so the state of exception can be legitimized. Elden suggests that it is perhaps the absence of sovereignty over territory itself that is unusual now (Ibid).

Continuing with false emergency situations, Matthew Sparke's view presents us with an interesting take on September 11th, and its consequences. Sparke argues that the contemporary issue of "geopolitical fears" - political fears and their implications, played a big role in how the war in Iraq, and post 9/11 policies were structured, and sold to the American public. His view, as a geographer analyzing $9 / 11$, is that America manufactures fear like a product that its citizens will all want to buy. Sparke asserts that fear has become an essential part of politics in the United States and this selling of fear was crucial in order to get the go ahead for the war in Iraq, from the general American public, as it never came from the international community or the United Nations. Sparke writes 
that it is unclear even now how fearful Bush was himself of the threat from Iraq and other "terrorists" in launching a pre-emptive war that is still ongoing, but somehow sold it to Americans (Sparke 2007, p. 341).

Sparke presents a view that asserts President Bush and his administration were very hopeful about where the war in Iraq would lead, as they presented a very passionate and fearful situation concerning Iraq, ranging from the certainty that Saddam had weapons of mass destruction (WMD), to the purchase of uranium yellow cake from Africa, to a more humanitarian interventionist view that he was horrible to his people. Although it is true that Saddam was not a democratic or good leader by any stretch of the imagination, most of the fears and accusations, we now know, were false. There was international suspicion that Bush and his administration had ulterior motives for going to war, and sadly soon after the war began, the "evidence" that Colin Powell so passionately presented at the United Nations, was found to be false. After wrecking an entire nation, no WMD were found, and the country that America claimed was such a big threat to the United States, found its leader hiding in a hole in the ground; hardly a real threat to America. The tactics used to reach the point where the public generally supported this war, however, are crucial. Sparke's view of fear mongering by the administration ties into how the public was being prepped, for something that actually was underway for over a decade. The pre-planned agenda was in place, and 9/11 opened the door. The threat of a rogue Iraq and Saddam Hussein was not a sudden threat; this was in the works for quite some time, as the chapter on the Project for the New American Century will show. 
Matthew Sparke analyzes these fears beginning with the "groundless fears" of Saddam and his WMD, his false ties to al-Qaeda, and the "correspondingly groundless geopolitical discourse that these fears underwrote about the threat posed by Iraq to American security" (Sparke 2007, p. 339). The geopolitical discourse of fear was presented in such a specific manner, carefully worded in all of Bush's speeches, and through this a plot was created. This plot had to be one that the American public would buy into because in the end they are the ones paying (Sparke 2007, p. 341). The "geopolitical imagining of an 'evil'”, as Sparke says, was essential in framing Saddam as a target. His analysis concentrates on how future fears sold the American public on acting in the present. He writes that

"It was specifically fear of this evil other that was most instrumental because it made it possible for the President and his administration to connect widespread and visceral feelings of insecurity among Americans in the post-9/11 present to much narrower and calculative concerns with America's strategic future. It was in this way that the futurological fears ironically became a retroactive justification for war" (Sparke 2007, p. $341)$.

It didn't matter how futuristic, real or unreal these fears were for the Bush administration. The chief of British intelligence later recorded in the Downing Street memos, "the intelligence and facts were being fixed around the policy' (Sparke 2007, p. 341). A very specific ideology was created by the constant fear mongering by the Bush administration. So much so that even after the invasion of Iraq, and even after WMD were not found, nearly 70 percent of Americans still believed that Saddam had been personally involved in the 9/11 attacks (Ibid). In an interview with Suskind in 2004, an unidentified Bush aide said 
"We're an empire now, and when we act, we create our own reality. And while you're studying that reality-judiciously, as you will-we'll act again, creating other new realities, which you can study too, and that's how things will sort out. We're history's actors, and you, all of you, will be left to just study what we do'' (Sparke 2007, p. 343).

Relating to the geopolitical fear that Sparke analyzes is something that Debrix calls "tabloid geopolitics". He defines it as

"The result of mediatized discursive formations that take advantage of contemporary fears, anxieties, and insecurities to produce certain political and cultural realities and meanings that are presented as commonsensical popular truths about the present condition" (Debrix 2008, p. 5).

According to Debrix, tabloid geopolitics played a big role in selling the war to the American public, by playing on their fears that according to Sparke were futuristic and false. To expand, tabloid geopolitics is a form that is taken by the media, especially in the United States, in matters regarding national security, war, and global terror (Debrix 2008, p. 5). Debrix says not only is it a medium, it is also a discourse, and all those who claim to speak in the interests of the public can partake in it (Ibid). However, used as a form of propaganda, and as it can be misleading, tabloid geopolitics is

"A discursive public enterprise that seeks to proliferate narratives and images intended to saturate and satisfy the global cultural landscape. However [Tabloid Geopolitics] ends up deploying vengeful and destructive strategies against enemies or "evil" figures that, it convinces itself, have to be the real cause of the terror witnessed in the primal scenes" (Debrix 2008, p. 5).

This explains much of what was going on in the media post $9 / 11$, leading into the war in Iraq. The media preyed on a vulnerable public and played on their fears to create a 
certain image that was fitting to what the Bush administration was trying to sell. Very few independent media sources were available in the United States during this time, which presented a more balanced view, and of those, none were mainstream. This twisted form of geopolitics was used to define evil from good; America from the "enemy". Debrix writes that America is "driven by hunger for victory" at any cost and stomps on "nameless territories, in placeless locales, and toward unclear enemies" (Debrix 2008, p. 77). Much of this is actually repeated by Bush administration members such as Rumsfeld, and Bush himself, as similar phrases about "unclear enemies" and wars that may be waged for an indefinite amount of time are easy to find in many speeches, post $9 / 11$, leading to the war in Iraq.

Geopolitical discourse was presented to us in many different ways during the days immediately after the attacks, leading into the war in Iraq, and even now. The geographical perceptions of danger had changed, and this point was spread quickly through the media. Iraq was in fact always on the agenda for the Vulcans and PNAC, but it was Al Qaeda's attacks that were used as the excuse to attack Iraq. On 9/11, Al Qaeda attacked America - not Iraq, but by presenting alleged ties between Iraq and Al Qaeda, Bush was able to successfully convince the American people to go to war with Iraq. Iraq was presented as a dangerous territory, which harboured Al Qaeda terrorists. This new form of danger, (terrorism) which was not territorially bound, was presented in a way that would skew public opinion into believing Al Qaeda the terrorist network and Iraq the nation were one of the same. PNAC and the Bush administration imposed the dangers 
associated with Al Qaeda on Iraq. This is a crucial point, because the shift in geographical perceptions of fear allowed this to happen.

The attacks and the realization that terrorism is something that merges national and transnational resulted in several geographical changes. Not least in the language being used to describe these changes, such as "homeland security" replacing "national security". Homeland security sounds less territorially bound and farther reaching in terms of protecting the United States. Since danger is seen to be lurking everywhere, so should be America's defences. Homeland security deals with the "new" dangers that Bush declared were born on 9/11. Theoretically, Bush argued that anywhere in the world could be dangerous, because terrorists themselves are dispersed throughout. Borders became the centre of focus once again. There are a few ways to look at the issue of borders and how they have changed post $9 / 11$. From one perspective borders meant nothing to the terrorists as they flew planes into the heart of America. Because of this realization, physical borders were tightened, not only in the United States but also internationally. The immediate increase in security at airports and especially at US-Canadian and USMexican borders was just the first step. Immigration laws also became more strict. All of this was meant to keep "them" on the outside, and away from "us". The geopolitical categories were made clear, and there was only one of two sides to be on. The geographical perceptions of danger significantly changed policy initiatives in the United States. As will be seen in upcoming chapters, the changes to constitutional rights and freedoms with new policies such as the Patriot Act were implemented, dramatically changing everyday life for some Americans. 
Another perspective on borders is that while physical borders were being tightened, the borders of America, in regards to protecting their interests stretched, becoming the whole world. The entire planet was the American homeland. 9/11 changed the geopolitics of borders in both these ways - physically at home with more security allowing fewer "in", and also by giving America unlimited scope in protecting its interests worldwide.

Sparke makes the important point that geopolitical fears ultimately created the excuse for the exception and for the invasion of Iraq. How we perceive danger, where we perceive it to be coming from, and who the targets are all factor into policy making and the consequences of the September $11^{\text {th }}$ attacks. The fear mongering that the Bush administration participated in created a certain view of danger, and what to be fearful of. Since danger is everywhere, legitimizing the exception was relatively easy in the immediate aftermath of $9 / 11$. The geopolitical imagining of an evil, as Sparke put it, led Bush to create sharp geopolitical categories of good and evil.

Much of our views are based on what we hear and see in the media, and what our leaders tell us. Many people take for granted that both our leaders and the media are there to protect us and tell us the truth, but in reality the media tends to be biased, and leaders may have ulterior motives. The amount of propaganda surrounding 9/11, Iraq, WMD, and everything else in between gave Americans a skewed view of events, and amidst the shock and panic, most of them bough whatever was being sold to them. Sparke's point 
about the intelligence being molded to fit the policies seems quite fitting. Double standards are blatantly obvious. Iraq had to abide by international law and U.N. sanctions, and the United States, it appeared, did not. The sovereignty of Iraq is presented as questionable, led by a leader Americans disapprove of.

These authors support the view that a permanent state of emergency was being established, one that made emergency the rule. George Bush saw himself as the decider ${ }^{2}$, and as outside the law in two cases. One, being internationally, and the other being domestically. As Gregory said, emergencies and the suspension of laws cannot be reduced to decisionism. It is one thing to call a state of emergency for a short period of time, however when that emergency becomes a rule, and America enters a permanent a state of exception, it seems the decider becomes a dictator, and the nation is technically ruled by one man, versus a constitutional system. America is in fact not a dictatorship. However the fact that theoretically, based on this model it could happen, or that the Bush presidency showed signs of acting like a dictatorship, proves to be a scary possibility.

What these authors are arguing via critical geopolitical analysis is that the perceptions of danger had changed, and this change in danger was the excuse for the exception and all that was to come after 9/11. What makes CGA a useful addition to the discussions surrounding $9 / 11$ and its consequences is that CGA focuses on taking apart the taken for granted beliefs by shedding light on how the change in perceptions of danger have been used as justification for policies, both domestic and foreign, and

2 "I hear the voices, and I read the front page, and I know the speculation. But I'm the decider, and I decide what is best" (Bush 2006 as cited in Henry \& Starr, 2006). 
ultimately the declaration of the Global War on Terror. Like political science, law, and IR theory, geography too has a unique way to analyze these events, and is a positive contribution to the discussion. All these authors have attempted to do this by critically analyzing the taken for granted beliefs in tabloid geopolitics, and the perceptions of danger involving futuristic geopolitical fears. They reintroduce the importance of borders and territory as crucial part of the analysis of $9 / 11$ 's consequences. Because of all these factors, CGA advances our knowledge and understanding of the exception by allowing us to see how geographical perceptions of danger were ultimately the excuse for the exception after $9 / 11$.

In the following chapter, the pre-planned agenda, represented primarily through the Project for the New America Century will be presented. Critical analysis of how it has influenced the Bush Doctrine, the war in Iraq, and domestic policies will also be analyzed in an attempt to prove that their influence had a large role to play in America's transformation from a state of emergency, to being in a state of exception. 


\section{CHAPTER 3}

\section{Axis of Evil: Project for the New American Century}

The pre-planned agenda is represented largely through the right wing think tank the Project for the New American Century (PNAC). By analyzing the ties this organization and its members had to the Bush cabinet, clear connections can be made about its influence on the Bush Doctrine. Not only that, but how some of the measures and policies that were implemented after $9 / 11$, had been ideas that the PNAC had for quite some time, and for various political reasons could not push through.

The analysis in the following 2 chapters will show an overlap between the Bush Doctrine and PNAC documents. In order to show the continuity in the themes, a cross reference between those documents will follow. PNAC will be presented in this chapter first, as a precursor to the Bush Doctrine, 9/11, and the GWOT. PNAC, and even more specifically the Vulcans, came far before Bush was elected President, and much before 9/11 could even be fathomed as a possibility. The members of PNAC and their views, documents, reports and other publications are crucial to what influenced Bush during his years in office, but more specifically to what influenced the way he proceeded after the attacks of 2001. In order to make this clear, this chapter is dedicated to PNAC's origins, members, goals, and agenda before 9/11, and before Bush.

The themes that are most important to PNAC are preeminence, preventive war, unilateralism, large increases in military spending, ensuring that there is no possible rival 
to America solidifying America as the most powerful nation on earth. Throughout this chapter, this will be made clearer, showing the logic behind PNAC's agenda. In the next chapter, an overlap with the Bush Doctrine documents will be evident, placing PNAC and the Bush Doctrine as "before and after" 9/11, making clear their connections, and continuities in themes.

Established in 1997, PNAC is concerned with America's defenses and holds that the decrease in military spending would jeopardize America's role as superpower in the world. PNAC's statement of principles declares that

"[What we require is] a military that is strong and ready to meet both present and future challenges; a foreign policy that boldly and purposefully promotes American principles abroad; and national leadership that accepts the United States' global responsibilities" (Abrams et al 1997).

Thought to be the brains behind the Bush Doctrine, this think tank has advocated for increased military spending, preserving and advancing America's dominance in the world and advocates pre-eminence as its main military strategy. Dalby writes that

"This PNAC blueprint was an explicit attempt to provide continuity with the earlier Cheney defence department planning in the first Bush administration. As such it provides a loosely consistent set of priorities and a geopolitical framework for a grand strategy based on military supremacy against any potential state rivals to American power" (Dalby 2006, p. 39).

The organization was formed during the Clinton years. However, Clinton ran a very different administration and therefore the PNAC didn't have much hope in him. However, the election of George W. Bush in 2000 opened up many possibilities. There 
are multi-layered connections between PNAC and the Bush administration but little is publicized about PNAC's influence in the Global War on Terror. A deeper look may shed some light on the links between the two. Many members of PNAC joined the Bush administration and became credible claims makers, who constructed news reports (Altheide and Grimes 2005, p. 624). At least 17 members of PNAC held positions in the Bush Cabinet; some more public positions then others. Among the members who laid down the foundation for a new American empire were former and current (at the time) governmental officials, including Jeb Bush, Dick Cheney, Steve Forbes, Donald Rumsfeld and Paul Wolfowitz (Ibid). Dick Cheney of course was Vice President to George Bush; Donald Rumsfeld became Secretary of Defense with Paul Wolfowitz being deputy secretary. Richard Armitage another member of PNAC was named Deputy secretary of state, and John Bolton was the Under Secretary of State for Arms Control and International Security Affairs, and later became U.S. Ambassador to the United Nations. This was a shocking pick to most people, as John Bolton is known for being a far right neoconservative who is known for having contempt for the UN and international law in general, and his views would suggest he believes in American supremacy. This is not shocking knowing his background as a PNAC member, but it was quite an extreme pick for the Bush administration.

Slowly but surely, other members joined the Bush administration. Elliott Abrams, who ranks high up in PNAC was appointed to direct the global democracy campaign and also appointed to oversee Middle Eastern Policy from his "perch in the National Security Council" (Barry 2005). Elliott became one of the Bush administrations highest profile 
officials, as he later acted as Bush's envoy to Europe and Israel among other responsibilities (Ibid). Other well known officials include Richard Perle who became chairman of the board for the Defense policy Board Advisory Committee and "Scooter" Libby, whose career ended in scandal, was Chief of Staff to Vice President Dick Cheney. Project directors William Kristol and Robert Kagan also have a long history of involvement in U.S. politics, and their influence on both Bush administrations has been significant. William Kristol was chief of staff to Vice President Dan Quayle during the first Bush Administration. He is also a regular on Fox news, and is editor of the Weekly Standard (Project for the New American Century 2010). Robert Kagan is co-founder of PNAC alongside William Kristol. He is a contributing editor to the Weekly Standard, a columnist for the Washington Post and has had a lot of involvement in the previous American administrations. From 1985-1988, Kagan was Deputy for Policy in the State Department's Bureau of Inter-American Affairs. From 1984-1985, he was a member of the State Department's Policy Planning Staff and principal speechwriter to Secretary of State George P. Schultz. In 1983, he served as foreign policy advisor to Congressman Jack Kemp and as Special Assistant to the Deputy Director of the United States Information Agency (Project for the New American Century 2010).

Although PNAC was formed in 1997, many of these members worked together in American administrations and on other projects dating back to the 1960 s and 70 s. Of all the members, the closest were a group who called themselves the "Vulcans", and comprised of Dick Cheney, Donald Rumsfeld, Colin Powell, Paul Wolfowitz, Richard Armitage and Condoleezza Rice (Mann 2004, p. x). In particular Cheney and Rumsfeld 
had several times worked together in the past, and as a team together within administrations (Mann 2004). Rumsfeld had first worked along Cheney three decades earlier, when Cheney served as Rumsfeld's administrative assistant in the Nixon Presidency (Mann 2004, p. x). Powell and Armitage had worked together during the Reagan years, alongside Wolfowitz. So when Bush campaigned for Presidency in 2000, then elected in 2001, the whole gang was back together again.

With these players on board, the Bush administration embarked on what some call the new American Empire. PNAC was a crucial part of the formula that led to the invasion of Iraq, especially on 'selling war' to the American public. They did this very carefully and without much media attention as key members worked backstage to make this all possible. Altheide and Grimes write that the invasion was planned and sold to the media "without making it widely known that a few very influential officials had been working to change foreign policy in general, and attack Iraq in particular, for about a decade" (Altheide and Grimes 2005, p. 620).

Their policy initiatives didn't really come into the spotlight until September $11^{\text {th }}$. Over the following year after 9/11, the Vulcans put forth a "remarkable serious of new doctrines and ideas" which represented quite a dramatic break from previous policies, especially foreign policies, which would suggest that a new doctrine was being put in place (Mann 2004, p. xii). Dalby writes that

'Once the events of September 11 were interpreted as a 'global' war on terror then the geopolitical categories from the first Bush administration and the PNAC documents shaped the subsequent prosecution of American policy. The specific geographies of $\mathrm{Al}$ 
Qaeda and struggles in the Gulf region were swept aside by the geographically inappropriate specifications of global struggle and the discursive repertoire of global security was awkwardly applied to the new circumstances in late 2001" (Dalby 2006, p. 42).

The goals and aims of Bin Laden and Al Qaeda were ignored, and applied to suit the current situation. Bush and his administration constantly asserted that Osama and $\mathrm{Al}$ Qaeda were just "evil doers", who hated America, Americans, democracy and their freedoms. They were reduced to inflicting terror for terror's sake, removing any type of political intention from their means. Of course the general public does not read any documents, or watch any videos made by members of these terrorist organizations, so majority of citizens believed in this story, especially after seeing first hand what terrorists were capable of in their own cities. Americans needed someone to blame, and channel their rage towards. Once Osama couldn't be found, they quickly started pointing to Saddam Hussein.

The PNAC publications have a tone of constant panic, trying to instill fear to gain support. They state that if the next President misses the opportunity to advance America forward in this time of 'peace' that the opportunity will pass and America will not be able to maintain its military hegemony. Furthermore, if this unipolar moment passes, America may not be able to regain its dominance again (Dalby 2006, p. 40).

One of the main PNAC documents entitled "Rebuilding America's Defences: Strategy, Forces and Resources for a New Century", published in 2000, just as Bush began his presidency, and one year before $9 / 11$, outlines its position on what it feels 
America's role should be in the world, primarily militarily. There are four main principles outlined by PNAC, which are as follows: 1) defend the American homeland, 2) fight and decisively win multiple, simultaneous major theater wars, 3) perform the "constabulary" duties associated with shaping the security environment in critical regions and 4) transform U.S. forces to exploit the "revolution in military affairs" (Donnelly 2000, p. v). In this document, it is specified that the organization seeks to build upon a defense strategy outlined by the Cheney Defense Department towards the end of Bush Senior's administration (Donnelly 2000, p. ii).

In the opening paragraphs of the document, PNAC states that

"At present the United States faces no global rival. America's grand strategy should aim to preserve and extend this advantageous position as far into the future as possible. The challenge for the coming century is to preserve and enhance this "American peace" (Donnelly 2000, p. i).

It contends that unless America maintains its military strength, their position may be in danger, and even go as far as to say that the "American Peace" is at a growing risk. Themes of pre-eminence, preventive war and unilateralism are both explicit and implicit throughout the report.

There is a great deal of attention given to the Persian Gulf, Saddam Hussein, and Iraq; keeping in mind its publication in 2000 , before September $11^{\text {th }}$. For example, reference is made to Hussein's possible acquisition and/or development of "weapons of mass destruction" (WMD) here: "Saddam Hussein...could begin a war - perhaps even 
while employing chemical, biological or even nuclear weapons (Donnelly 2000, p.ii). And again, here:

"Indeed, the United States has for decades sought to play a more permanent role in Gulf regional security. While the unresolved conflict with Iraq provides the immediate justification, the need for a substantial American force presence in the Gulf transcends the issue of the regime of Saddam Hussein" (Donnelly 2000, p. 14).

Language around (re)introducing Iraq as a significant threat and Saddam as a problem for American peace is evident, even before the assumptions that Bush made attempting to link $9 / 11$ to Hussein's Iraq. Repeated again in a book written by top members of PNAC called Present Dangers, Iraq is mentioned in terms of how the Clinton administration had "wrongly" handled the situation. They say that in the face of these challenges, they cannot continue on the route Clinton had established in engaging in a "gradual but steady moral and strategic disarmament", but should instead "seek to unseat the dangerous dictatorships in Baghdad and Belgrade" (Kagan and Kristol 2000, p. 7). They call Clinton's diplomatic accommodations ineffectual and call for a more aggressive method. Once more, even before $9 / 11$, ideas of preventive war may have been looming in the mind of neoconservatives. After $9 / 11$, their ideas were articulated in foreign policy and most notably in the invasion of Iraq.

A more explicit position on Iraq is stated in a latter part of the book saying that instead of ending the Gulf War in 1991, the US should have stayed there long enough to remove Saddam, enforced regime change and kept US troops in Iraq long enough "to ensure that a friendlier regime took root" (Kagan and Kristol 2000, p. 19). Interestingly, 
they make this comment in the book: "to many the idea of America using its power to promote changes of regime in nations ruled by dictators' rings of utopianism. But in fact, it is eminently realistic" (Kagan and Kristol 2000, p. 20). Even after the invasion of Iraq, the removal of Saddam, the regime change and the "friendlier" leader the PNAC had called for, the country is still in chaos.

The persistent references to unseating Saddam Hussein continue. The authors argue that to "cling to the sanctions and hope for the best" will not protect American interests in the region; furthermore they claim that "stability" (In Iraq) has kept the Clinton administration from taking the risks involved in waging a campaign to remove Saddam from office (Kagan and Kristol 2000, p. 10). At the time, Iraq had not attacked America; in fact Iraq never attacked America. It is much harder to persuade the American public to go to war for no reason other than protecting American interests. After 9/11 however, by forcefully and falsely connecting Saddam to the September $11^{\text {th }}$ attacks, they found public support to finally unseat Saddam; ideas proposed by PNAC but not enacted until Bush came to power.

Policies such as these blur the territorial sovereignty lines of nation states. Nowhere is it "legal" for one country to determine what kind of a regime another country should have (ex. A "friendlier regime"). The fact that for whatever reason one nation can decide what is in the best interest of another, and furthermore physically invading it, compromises that nations' sovereignty. To invade a nation, and to replace its leader with one more suitable to America, crosses many borders and rewrites the geopolitical map. If 
anything, there is more chaos in this situation, than the chaos that was present when Saddam was in power. America is controlling the government in Iraq to an extent by putting a puppet (that is suitable for America) there in place of Saddam. This, in turn creates more resentment towards America, and does not solve any of the "terror" threat issues that PNAC was addressing in its documents - in fact, it makes them worse. If a person is attacked, they will more than likely fight back. The same goes for a nation. When the nation's space is invaded, it is natural to want to fight back and harbour anger toward the invaders. In no way will this preserve peace. But peace is not what America is after, it is only a cover for the other motives the government has. Again, the citizens know this as well, which adds to the hostility, and adds to the chaos. Some of these motives are explicitly outlined in PNAC documents under such guises as "responsibilities" and "preserving peace" and so on.

In regards to handling other threats, the PNAC proposes a more aggressive role for America in the world; one that is not dominated by diplomacy and passivity. This is articulated in Present Dangers:

"The middle path many of our political leaders would prefer, with token increases in the defence budget and a more humble view of America's role in the world, will not suffice. What is needed today is not better management of the status quo, but a fundamental change in the way our leaders and the public think about America's role in the world" (Kagan and Kristol 2000, p. 9).

Also, the idea of preserving "Pax Americana" or the American Peace is strongly articulated. This is seen as an obligation, a duty and a responsibility, which parallels 
some aspects of U.S. exceptionalism. This is evident in the language used in this report, and others published by PNAC. The organization states that Pax Americana is "the mission to transform U.S. military forces to meet new geopolitical and technological challenges", while maintaining a superior position and simultaneously preserving the peace (Donnelly 2000, p. 11). Along side global leadership, maintaining world peace is seen as some sort of manifest destiny, not asked for, but needs to be fulfilled. In the National Security Strategy (2002), Bush echoes this point. In fact, in comparison to various State of the Union speeches, and the NSS of 2002, the PNAC document is shockingly similar. The latter states

"Global leadership is not something exercised at our leisure when the mood strikes us or when our core national security interests are directly threatened; then it is already too late. Rather, it is a choice whether or not to maintain American military pre-eminence, to secure American geopolitical leadership, and to preserve the American peace" (Donnelly 2000, p. 75).

This is the essence of Hardt and Negri's exceptionalism. The quote from the document presents the view that global leadership is a responsibility that America has not asked for, but must fulfill, i.e. the responsibility of governing the world, and more or less, to preserve some sort of "peace". It is presented in such a way as if America is the wise parent who knows what is best for its children (i.e. the rest of the world). Continuing with this idea, several other times in the report, the idea of America as protector of world peace is reiterated. In order to achieve/preserve military hegemony, development of nuclear weapons and ballistic missile defense is strongly advocated. The argument is as follows: with great power comes great responsibility. However true that may be, PNAC has portrayed developing nuclear weapons and funding ballistic missile defense as a way 
to preserve peace in the world. The 2000 PNAC report says in order to maintain preeminence and defend America, they must "move more aggressively to experiment with new technologies and operational concepts, and seek to exploit the emerging revolution in military affairs (Donnelly 2000, p. 12). It goes on to say, "effective ballistic missile defenses will be the central element in the exercise of American power and the projection of U.S. military forces abroad" (Ibid, 12).

Why the United States has to exercise military power in the first place remains questionable, as are the methods to achieve this. PNAC sees the development of nuclear weapons, while banning other nations from acquiring them, a fair route to international peace. This is again echoed by the Bush administration shortly after this publication. The emphasis on weapons in space is also made in several sections of the report. One example is here: "No system of missile defences can be fully effective without placing sensors and weapons in space" (Donnelly 2000, p. 54). Reiterated in Present Dangers, they emphasize America's "job". According to them, "America's job is to preserve and reinforce America's benevolent global hegemony...the goal of American foreign policy should be to turn a unipolar moment into a unipolar era" (Kagan and Kristol 2000, p. 6). Kagan and Kristol echo much of what is written already in previous PNAC publications which is that the United States should first look to secure its own immediate interests and then concentrate on its "broader responsibilities it has once assumed as leader of the Free World" (Kagan and Kristol 2000, p. 10). The rhetoric of America being the leader of the world is something that Bush has repeated on several occasions; in his State of the Union speeches, speeches to the nation after $9 / 11$, and in official documents such as the NSS. It 
is important to note these here so that when documents from the Bush Doctrine are analyzed later, it will be possible to make a comparison.

Tones of constant panic and manipulations of statements to provoke fear can be found throughout their published materials. Interestingly enough, PNAC names threats that later were named a part of Bush's "Axis of evil". PNAC asserts that America "cannot allow North Korea, Iran, Iraq or similar states to undermine American leadership, intimidate American allies or threaten the American homeland itself "(Donnelly 2000, p. 75). And again "American pre-eminence cannot be maintained from a distance...because eventually, the crises would appear at our doorstep" (Kagan and Kristol 2000, p.11). This closely resembles the point Bush makes about attacking the terrorists 'there' before they reach 'here' and a "mushroom cloud" is seen in American cities. As he famously said

"America must not ignore the threat gathering against us. Facing clear evidence of peril, we cannot wait for the final proof -- the smoking gun -- that could come in the form of a mushroom cloud" (Bush 2002b).

The last and crucial point here is that the PNAC says these changes are unlikely to come about quickly unless there is "some catastrophic and catalyzing event - like a new Pearl Harbor" (Donnelly 2000, p. 51). And that is exactly what happened, comparable to foreign attacks on American soil, 9/11 changed the course of things to come in the White House, and for the world.

On October 15, 2001 the Weekly Standard, a magazine published by top members of PNAC, printed an article called "The Case for American Empire; The most realistic 
response to terrorism is for the United States unambiguously to embrace its imperial role”. Max Boot, the author, argues that although many people think 9/11 was some sort of payback for US imperialism, and the solution would not be to be a "kinder" America, one that is a "republic, not an empire" the opposite should actually occur (Boot 2001). In Boot's view, September $11^{\text {th }}$ "was a result of insufficient American involvement and ambition; the solution is to be more expansive in our goals and more assertive in their implementation" (Ibid). He then poses the question, now that America has been attacked should it act as the "great power" that it is? Shortly after $9 / 11$, the plans that PNAC had been brewing for years started to come into the light. For example, again in the Max Boot article, a lot of focus is placed on Saddam Hussein. At that time, the focus should have been on how to find Osama Bin Laden, just weeks after 9/11. However, the spotlight started drifting towards Saddam and Iraq. Saddam was totally unlinked to the attacks of 9/11 but somehow was suddenly centre stage. Except it isn't sudden. PNAC had been preaching about Iraq for years before Bush ever came into power or September $11^{\text {th }}$ ever even happened. Boot writes in his article:

"Saddam Hussein is a despised figure whose people rose up in rebellion in 1991 when given the opportunity to do so by American military victories. But the first Bush administration refused to go to Baghdad, and stood by as Saddam crushed the Shiite and Kurdish rebellions. As a shameful moment in U.S. history, the abandonment of these anti-Saddam rebels ranks right up there with our abandonment of the South Vietnamese in 1975. We now have an opportunity to rectify this historic mistake" (Boot 2001).

Saddam had nothing to do with $9 / 11$, but since they could not find Osama, manipulating Americans into believing that Saddam has the capabilities to destroy America was the next best bet as America had plans for Iraq long before 9/11. Since citizens were already 
fearful post $9 / 11$, and they were vulnerable, and (in hindsight) gullible, it was the perfect time to push for an invasion of Iraq. Again, in the same article Boot recognizes the fact that Saddam may in fact had nothing to do with the September $11^{\text {th }}$ attacks, but brushes it off as unimportant. He writes, "The debate about whether Saddam Hussein was implicated in the September 11 attacks misses the point. Who cares if Saddam was involved in this particular barbarity?" (Boot 2001). He goes on to say because he was involved in so many other barbaric acts against his own people and the Kurds; his removal should be the focus of American military efforts.

At the time America invaded Iraq, the latter was totally broke, and now we know had no weapons of mass destruction. However, the case was made to invade not only because Saddam had weapons of mass destruction, and he was going to use them against his enemies, including America, but also for the "freedom of Iraqi people". Later, when no weapons were found, the importance of the Iraqi people and their freedom was used as the central justification for going into Iraq. Again, this crosses so many boundaries and sovereignty lines, as war always does, but this one was a little different. There was no direct attack on America, and it was not done in immediate self-defense. If it is an issue of humanitarian intervention, then it should have been structured differently, and with the help of the United Nations. After the invasion, Kofi Annan declared it an "illegal" war, and it was clear that this was not a humanitarian mission. However to help their image, America assembled a "Coalition of the Willing", which wasn't very substantial, and the U.K. and Australia were the only main contributors in terms of monetary and military assistance. 
PNAC's influence has been written about by several authors but not accentuated in the media, therefore average Americans aren't exposed to this information. David Armstrong has emphasized the influence of PNAC over the Bush administration:

"The plan is for the United States to rule the world. The overt theme is unilateralism, but it is ultimately a story of domination. It calls for the United States to maintain its overwhelming military superiority and prevent new rivals from rising up to challenge it on the world stage. It calls for dominion over friends and enemies alike. It says not that the United States must be more powerful, or most powerful, but that it must be absolutely powerful" (Armstrong as cited in Altheide and Grimes 2005, p. 624).

President Bush justified the pre-emptive strike against Iraq, a sovereign nation, by repeatedly claiming that Saddam Hussein was linked to attacks on the United States, that he had not complied with United Nations about weapons inspections, and still possessed numerous weapons of mass destruction (WMD) that he planned to use against the United States (Altheide and Grimes 2005, p. 618). Now that all is said and done, we know this was not true. The members of PNAC, who were also part of the Bush administration, "set terrorism within a broader discourse of fear", using every excuse they could come up with to link September $11^{\text {th }}$ and Saddam together so that they could carry out their decade long plan of an invasion (Altheide and Grimes 2005, p. 632). On September 12, 2001, "without any evidence of who the hijackers were, Rumsfeld demanded that the U.S. attack Iraq" (Ibid). This is a crucial point, and says a lot about prior intentions. Rumsfeld was a key member of PNAC. He expressed that Iraq should be "a principal target of the first round in the war against terrorism" (Ibid). The reason that Iraq was not immediately attacked was because then Secretary of State Colin Powell said that there had to be wide 
public support of such an attack and therefore the invasion was put off, to Rumsfeld's disappointment, for another two years (Ibid).

The Invasion of Iraq was not a response to 9/11. In fact, 9/11 was the excuse for an attack that was pre-planned. PNAC actually used Al Qaeda and what had happened on 9/11 as an excuse for Iraq. It is interesting to note that in all of the documents surrounding PNAC (statement of principles, Present Dangers, The Weekly Standard and Rebuilding America's Defences) little to no references are made to terror or terrorism as anything outside the state. The language surrounding danger and threats are always regarding other states; either failed states or rogue states, but always states. PNAC could not have imagined that an attack on America could have come in the form of terrorists hijacking planes in NYC - a non-state action. Additionally, the inability for the American administration to properly respond to 9/11, upon great pressure from the Vulcan's, further perpetuated the problem. The occupation of Iraq continues to be a disaster. Despite all the technology and armed forces, and all the increases in military spending PNAC advocated for, they still do not have the nation under control, in a stable way. The American administration seemed to have blown their chances in Iraq, and instead of reasserting American preeminence; they only further isolated themselves from the international community, the United Nations and also damaged their image to the world. So in hindsight, although PNAC wanted the invasion of Iraq, it poorly used 9/11 and Al Qaeda as an excuse, leading ultimately to failure in Iraq. 
Returning to the Boot article from the Weekly Standard, another interesting statement is made which would imply plans for Iraq were brewing long before 2001 .

"Once Afghanistan has been dealt with, America should turn its attention to Iraq. It will probably not be possible to remove Saddam quickly without a U.S. invasion and occupation -- though it will hardly require half a million men, since Saddam's army is much diminished since the Gulf War, and we will probably have plenty of help from Iraqis, once they trust that we intend to finish the job this time. Once we have deposed Saddam, we can impose American-led, international regency in Baghdad, to go along with the one in Kabul. With American seriousness and credibility thus restored, we will enjoy fruitful cooperation from the region's many opportunists, who will show a newfound eagerness to be helpful in our larger task of rolling up the international terror network that threatens us" (Boot 2001).

The language in the article does not even attempt to hide any intentions. For example "we can impose an American led international regency." (Boot 2001). Also taken for granted is that Iraqi's will welcome the American troops into their nation. Years later we can see the "plenty of help" they expected to receive from Iraqis was not present.

One of PNAC's key points is unilateralism, which is later seen as a main point in the "Bush Doctrine". PNAC has advocated first and foremost, to maintain American preeminence, unilaterally whenever necessary. On June 4, 2001, months before September $11^{\text {th }}$, the Weekly Standard published an article by Charles Krauthammer; one of the contributing editors of the paper entitled "The Bush Doctrine; ABM, Kyoto, and the New American Unilateralism". In this article, unilateralism is advocated as necessary and is presented as so in a section called the "purposes of unilateralism". This is what Krauthammer had to say: 
"[The purpose of Unilateralism is] not just because we enjoy our own power ("It's good to be the king" -- Mel Brooks), but because it is more likely to keep the peace. It is hard to understand the enthusiasm of so many for a diminished America and a world reverted to multipolarity. Multipolar international structures are inherently less stable, as the catastrophic collapse of the delicate alliance system of 1914 definitively demonstrated. Multipolarity, yes, when there is no alternative. But not when there is. Not when we have the unique imbalance of power that we enjoy today -- and that has given the international system a stability and essential tranquility it had not known for at least a century" (Krauthammer 2001).

The author is clearly stating his opinion that multilateralism is weak, and unilateralism is the best system, led of course by the United States. To maintain peace it is probably best to at least act as if states are on a somewhat equal playing field. Dictating to other states what is best for them will create hostility, not peace. America's conceptions of this have always been skewed, as they believe they are destined to protect the world. This has transpired in their foreign policies, and although they keep turning negative results, they keep persisting.

Pre-emptive strikes were a key theme of PNAC documents and central to the Bush Doctrine. In a different article in the Weekly Standard on December 24, 2001, when the invasion of Afghanistan was already underway, the magazine published an article on Rumsfeld's ideology entitled "Rumsfeld's Just War; Generals meet theologians at the Pentagon". Author Joe Laconte writes that in when "extremists are seeking to acquire weapons of mass destruction, what otherwise would look like an offensive strike is, strategically speaking, defensive" (Laconte 2001). Laconte is saying that in order to defend the homeland, America must attack all potential threats. Rumsfeld said "selfdefense means you must go after them. You don't have a choice. And that gets you to pre- 
emptive strikes," (Ibid). Pre-emptive strikes quickly defined the Bush Doctrine, and Bush era post 9/11 through the end of his presidency. Long before anyone knew what the Bush Doctrine would become, PNAC was already pushing for pre-emption.

In subsequent State of the Union addresses after 9/11, many countries were named to the list of potential dangers. These included Cuba, Iran, Syria and North Korea - all of whom, at some point, posed a national security threat to the United States (Gregory 2006, p. 407). This is exactly what PNAC set out to achieve. By entering a state of exception, the Bush administration now regarded itself as a global sovereign that had to protect itself and the whole world from terrorists (Ibid). This would involve having American bases everywhere in the world, especially the Middle East, securing strategic benefits for the United States. Bush's thought process is that "'the 'war on terror' will not be hamstrung by what it views as outmoded legal protocols" (Gregory 2006, p. 408). It has exempt itself from all legal consequences nationally and internationally as emergency measures had been adopted as the rule, and therefore into law. This relates again to Hardt and Negri's U.S. exceptionalism, as well as the theories surrounding states of exception. Especially in the first case, The United States has exempt itself from what they believe are outdated legal protocols, and unilaterally taken on the role of protector of global peace. Proving that they (America) can do what they want, how and when they want, with no regard for laws, both international and domestic.

So if WMD weren't the real reason, and Saddam was not a threat, and given that there are no immediate threats, what is PNAC advocating for? Why are they advocating 
such extreme measures? Firstly, permanent war is a new way to organize society. It is the easiest way to control every aspect of people's lives domestically, and to command a greater presence on the global stage. George W. Bush himself jokingly (or maybe not) said Dictatorships are much easier to manage than democracies. Maybe this is because you do not need the consensus of the people. The problem with that is Dictatorships have no legitimacy, especially within the international community. The international community looks down upon dictatorships, as Democracy is seen as the ideal model. Bush's references to himself as the decider have a scary tone of a dictator hidden in them. It seems that perpetual war and fear make us want to trust our leaders more, and allow them to call the shots and really be "deciders" in big ways. It gave Bush the support he needed to go into Iraq from the American public, even when the United Nations was against it.

As we can see in the Boot article, whether or not Saddam was involved in $9 / 11$ is passed off as a minor detail in the grander scheme of things. The larger scheme - the Grand Strategy that PNAC pushes for (then later the Bush administration implements) is American dominance, American control over the world's natural resources, the international community and control over other nations politics when beneficial to them. They are advocating a new order, a new way to organize, a new form of violence basically a new world, with America as its sole leader. Its ultimate goal is to ensure no greater rival will emerge, keeping America as the world's only and greatest superpower.

In order for some nations, or a single nation to be superior, that must mean other 
nations are to be kept inferior. Not everyone/nation can be rich and wealthy. The entire order would be disrupted should "equality for all" ever be implemented. Americans live a certain way, because others in the world do not. They have SUV's, mansions, pools, and high salaries because somewhere in the south they can't afford cars, houses, and work for as little as one dollar a day. McKinley argues that

"...The condition of the global South as a necessary condition of the North's status quo. In the global context of the war on terror and US leadership neither can be admitted. Nor can the condition of the global South as the principal casualty of this war..." (McKinley 2007, p. 37)

There is only so much wealth to go around, and as Michael McKinley would suggest, in the larger scheme of things its more than just about Iraq, military power, or domestic control.

"Rising powers and possible threats (albeit with insufficient attention to political Islam) from the central unifying enemy, the Soviet Union, but also in Central Asia, Central America and the Middle East, satisfy the need for geostrategic anxiety globally and locally. Implicitly, Western Europe and the United Nations (UN) are downgraded, as is the doctrine of deterrence. Quite explicitly, the solutions are to be found in the continuation of both US financial might and the technological superiority it will enjoy over all rivals (Mckinley 2007, p. 18)

All the solutions to these problems the world faces, and America's self-appointed role as global policeman, including the preservation world peace only benefits them, and their allies of course. In the end, if they invade a nation, they negotiate some sort of control over their natural resources with the new (and usually American friendly) government in place. They have bases in strategic areas of the world, like Iraq, that 
benefit them in several ways. And all the fear about foreign threats, WMD and such, help them control the situation at home, with implementations such as the Patriot Act.

Keeping in mind that the foundations for what PNAC is advocating was set in 1997 , long before September $11^{\text {th }}$, or George Bush was in power, a strong overlap exists in the foundations of what makes up the Bush Doctrine. In the next chapter, many of these will be exposed and clear connections are made illustrating that the PNAC heavily influenced the Bush Doctrine, especially the National Security Strategy (NSS) of 2002. Additionally, some of the sections of the Patriot Act and the official 9/11 commission report will be reviewed in attempts to connect all of these pieces together to reveal a grand strategy that was in the making years before Bush even took office, and before the attacks of 2001. Once these connections are made, a bigger picture will emerge that shows a very different story of $9 / 11$. 


\section{CHAPTER 4}

\section{Window of Opportunity: The Birth of the Bush Doctrine}

This chapter will assess some of the most important documents pertaining to this thesis. First and foremost the birth of the Bush Doctrine will be discussed. What came to be known as the "Bush Doctrine" wasn't introduced until after September 11, 2001. There are three main principles to the Bush Doctrine. They are preemption, unilateralism and preventative war. Later an in depth analysis of the National Commission on Terrorist Attacks (9/11 Commission report), the NSS of 2002 and the Patriot Act will follow. These documents will be critically analyzed, in attempts to draw out common themes and similarities, which are central to this analysis, as it will give us a closer, look at the preplanned agenda that was waiting for an event like $9 / 11$ to be implemented.

As the previous chapter was a discussion and analysis of PNAC, this chapter will mainly be dedicated to the Bush Doctrine, showing how the documents discussed in chapter 3 may be cross referenced to those of the Bush Doctrine. PNAC is what came before the 9/11 attacks, and before President Bush was elected. The members that were a part of the "Vulcans" and of PNAC, are now in this chapter as members of Bush's administration. Their roles have changed, and so they hold more power. While keeping their ties to PNAC, it will become more evident in this chapter just how influential the think tank was on Bush's policies, allowing their agenda to be pushed through. 
Therefore, this chapter represents what came after the 9/11 attacks. Not only will the Bush Doctrine be discussed, but the above-mentioned documents will also be used as a way to cross reference the agenda of PNAC to what came after 9/11 under Bush. Themes of preeminence, preventive war, unilateralism, military spending increases, and American global dominance are also present throughout this chapter. The purpose of this chapter is to show the similarities in the documents and policy actions after $9 / 11$ with those of the ones drafted and written by members of PNAC before $9 / 11$. The goals of this chapter are to show how the geographical perceptions of danger, allowed the exception to be used as an excuse to transform America on many levels. Looking at the before and after of $9 / 11$ allows us to have a clear view of the continuities in the themes, what their origins were and how they were eventually implemented.

During the first nine months of the Bush presidency, Bush was having issues organizing his staff and appointing his judges, and was often seen "vacationing" on his ranch in Texas. He hadn't taken on the role of a leader, and the public was becoming disappointed, and his approval ratings were down. However, in the days and weeks after 9/11, a very different Bush emerged. "Addressing the nation immediately, Bush had declared that America would make no distinction between those who planned the attacks and those who harboured them; this was the birth of the Bush Doctrine" (Durham 2004, p. 259). Because of this declaration, Bush made a pitch to congress, and to America, to dramatically increase military spending. Bush started to sound in tune with PNAC's aims: 
"It costs a lot to fight this war. We have spent more than a billion dollars a month -- over $\$ 30$ million a day -- and we must be prepared for future operations.... We need to replace aging aircraft and make our military more agile to put our troops anywhere in the world quickly and safely" (Bush 2002).

This point is repeated over and over again, in different ways, with a few central goals- to justify the war as needed to protect the peace in order to justify high levels of military spending. This is also part of the greater plan that PNAC had in place, which is essential global dominance. Another example can be found here

"My budget includes the largest increase in defense spending in two decades, because while the price of freedom and security is high, it is never too high. Whatever it costs to defend our country, we will pay" (Bush 2003).

Implications of the Bush Doctrine are most obviously observed in reference to the Global War on Terror (GWOT), and most notably in the invasion of Iraq. PNAC had predicted that only a catastrophe could bring revolutionary change, and on September 11, 2001 , the revolution began. Before we knew it Iraq was a terrorist state. It was Osama Bin Laden who attacked America, but unable to find him and having interests in Iraq and in the region (more generally), Bush went after Saddam.

"Before September the 11th, many in the world believed that Saddam Hussein could be contained. But chemical agents, lethal viruses and shadowy terrorist networks are not easily contained. Imagine those 19 hijackers with other weapons and other plans, this time armed by Saddam Hussein. It would take one vial, one canister, one crate slipped into this country to bring a day of horror like none we have ever known" (Bush 2003)' 
Although there were supporting nations, only England and Australia made significant contributions with troops and funds; it had no support from the UN or the majority of the international community, being more or less categorized as a unilateral effort. Additionally, it was a pre-emptive strike. America waged a preventive war on Iraq assuming they had WMD that in fact did not exist. After they could find no such weapons, suddenly the rationale was shifted to "freeing the Iraqi people", as it is made obvious from the name "Operation Iraqi Freedom". However, in the months before America invaded Iraq, the language of the Bush administration sounded very similar to that of PNAC when warning against Iraq in their published reports. An example of this can be found in Bush's State of the Union address here:

"Iraq continues to flaunt its hostility toward America and to support terror. The Iraqi regime has plotted to develop anthrax and nerve gas and nuclear weapons for over a decade. This is a regime that has already used poison gas to murder thousands of its own citizens, leaving the bodies of mothers huddled over their dead children. This is a regime that agreed to international inspections then kicked out the inspectors. This is a regime that has something to hide from the civilized world" (Bush 2002).

The special attention PNAC gives to Iraq is echoed by Bush, using similar tactics of fear and uncertainty and a need to protect Pax Americana. In the State of the Union address in 2003, a month or so before the invasion of Iraq, Bush's address was dominated by mentions of Saddam Hussein. Suddenly his human rights violations were not acceptable to America. Not that they were "acceptable" before, but they had not previously made attempts to bring to light Saddam's human rights violations in such a way that it would warrant military action against him. Several references were made to 
his treatment of women, minorities, and his violations of UN agreements. One of the main parts of his speech and attack on Saddam rests on the assumption of weapons.

"Year after year, Saddam Hussein has gone to elaborate lengths, spent enormous sums, taken great risks to build and keep weapons of mass destruction. The only possible explanation, the only possible use he could have for those weapons, is to dominate, intimidate or attack" (Bush 2003).

By using the fear and sympathies of $9 / 11$, Bush began to plan for an invasion, just as PNAC had proposed. Bush began to create a fear of Saddam to the American public, so that public support would be in place for an invasion. He tried to justify the billions of dollars spent on the war, and how military equipment needed to be replaced to fight the war for the safety of Americans. One of PNAC's main goals was to increase military spending as they thought current levels were insufficient and made the military weak and unprepared.

Bush made several attempts at convincing the American public in 2003 during his State of the Union address to pursue preventive war against Iraq. In reference to Iraq, he says, "Some have said we must not act until the threat is imminent. Since when have terrorists and tyrants announced their intentions, politely putting us on notice before they strike?" (Bush 2003)

On September 15, 2001, right after the 9/11 attacks, Osama bin Laden and alQaeda were named as primary suspects, and according to Elden "it was a short step to 
position al-Qaeda in Afghanistan" although there was internal struggles within the administration regarding attacking Afghanistan first, or going straight to Iraq (Elden 2009, p.4). Two weeks after that, on October 1, 2001, the Weekly Standard published "An Open Letter to the President", signed by almost all members of PNAC, urging a wider approach (Elden 2009, p. 16). Among the suggestions were to obviously capture and kill Osama bin Laden as primary goal, but stated that it should not be the "only goal". The next proposed step was invading Iraq, suggesting that

"Even if evidence does not link Iraq directly to the attack, any strategy aiming at the eradication of terrorism and its sponsors must include a determined effort to remove Saddam Hussein from power in Iraq. Failure to undertake such an effort will constitute an early and perhaps decisive surrender in the war on international terrorism" (Elden 2009, p.16).

It seems pretty clear from the above passage that plans for Iraq were long in the making, and 9/11 presented a unique opportunity, and maybe the closest the Bush administration would ever get to coming up with a legitimate excuse to attack Iraq. Elden writes, "the justification for action against Iraq was based on a number of conflicting and contentious claims" (Elden 2009, p. 112). Among them were Saddam's links with and/or harbouring terrorists, his threat to neighbours (especially Israel), and of course the main argument that he was pursuing, or already had weapons of mass destruction (Ibid). "This was both a confused, and intentionally confusing, rationale," writes Elden, and he is correct (Ibid). All these reasons were distractions, some had legitimacy, and some were just made to portray a scarier Saddam, so that the public would be behind the administration when it decided to go to war. Apart from these reasons, in a speech Bush also said that 
" [America's] presence in the world is more than just our might; but our might is needed in the world right now to make the world a more peaceful place. The war on terror is not confined strictly to the al-Qaeda that we're chasing. The war on terror extends beyond just a shadowy terrorist network. The war on terror involves Saddam Hussein because of the nature of Saddam Hussein, the history of Saddam Hussein and his willingness to terrorize himself. Saddam Hussein has terrorized his own people. He's terrorized his own neighbourhood. He is a danger not only to countries in the region.... he's a danger to the American people. And we've got to deal with him. We've got to deal with him before it is too late" (Bush 2003).

Pre-emption is the key characteristic of the Bush Doctrine, and goes so far as to suggest the United States "claim a right to preempt danger", to basically take action before threats even materialize (Elden 2009, p. 112). The legal advice that was given to Congress suggested that Iraq could not be presented as an "imminent threat" that would justify preemption unless they could prove Iraq had weapons of mass destruction and links to terrorist groups that might use them against America (Elden 2009, p. 112). According to British Attorney General Lord Goldsmith "this is not a doctrine which, in my opinion, exists or is recognized in international law" (Ibid). However, as Bush already stated, he "doesn't know" what international law is.

At the heart of the Bush Doctrine is pre-emption and preventive war. The idea that America has "the right to assert its power to reshape the rest of the world" has not suddenly emerged, as noted earlier, but has been more prominent in the post 9/11 Bush era, and furthermore defined the Bush Doctrine (Dalby 2005a, p. 3). The Bush doctrine, "a doctrine that justifies pre-emptive strikes against adversaries who pose an imminent threat to US security" was heavily influenced by the PNAC (Abelson 2006, p. 204). However, in the context of a "Global War on Terror", Bush's words mark a difference in 
the way that $9 / 11$ was handled. For example, on September 12th, Bush said, "the deliberate and deadly attacks which were carried out yesterday, against our country were more than acts of terror. They were acts of war" (Elden 2009, p.3). By saying that alone, that the attacks were an "act of war", Bush has declared it as such, and proceeded to treat everything thereafter as war. Iraq and Afghanistan were used as concrete distractions, as "terror" itself cannot be attacked. In order to actually go to war with terrorism, as Bush suggested, central terror breeding grounds were chosen as points for attack.

With America leading the new Global War on Terror, it took on the role as a global leader yet again. With the events of $9 / 11$, and the Bush administration taking over the White House, the idea of America the leader had re-surfaced in full force. PNAC can be linked directly to the Bush Doctrine, as its main principles were eventually adopted and administered. The constant language of panic and crisis that PNAC sets forward implies that it is crucial to act now. The organization has asserted these ideas for a long time, and through $9 / 11$ they were granted their window of opportunity. Dalby writes that the National Security Strategy (NSS) codified the Bush Doctrine into law in 2002 (Dalby 2005a, p. 14). Mentioned in the NSS is that the U.S. "will, if necessary, act preemptively..." concerning a number of issues and in addition "without sanction from the United Nations or any other organization" for that matter because they have entered into a permanent "preventive war mode" (Ibid). This basically makes it 'okay' for the United States to attack without proper evidence, just as they did in Iraq. Colin Powell's speech at the United Nations on how Saddam Hussein had WMD - although he didn't - was almost a courtesy to the international community, as they went on without the support of the United Nations. It is evident that the GWOT, via the Bush Doctrine has ultimately 
shifted geopolitical definitions and categories. According to the Bush Doctrine, and Bush himself "we will make no distinction between the terrorists who committed these acts and those who harbour them" (Bush as cited in Elden 2009, p.3). As one of Bush's speech writers David Frum said, "with those words, Bush upgraded the war on terror from metaphor to fact" (Elden 2009, p.3).

The language that is used in the Bush Doctrine and documents from PNAC and the NSS clearly state the "need for American global leadership". It is possible that this view may provoke more terrorist attacks than prevent them. America is seen as intrusive into the internal affairs of other nations, and at times forcing their values and policies upon them, the Middle East in specific. There are many populations in the Middle East, and terrorists as well, that have spoken out against this and several authors have sourced this as a reason for contention. Bush presented a view that America was attacked by the "evildoers" out of hate for the American people and their way of life. However, in reality, it was a strategic action meant to have effect on American foreign policy. Dalby writes

"This is a misunderstanding or purposeful misconstruing of the intentions of terrorists because it wasn't an attack on their freedom or the people themselves. It was an attack on the system of American Imperialism in the Middle East" (Dalby 2005a, p. 16).

America's refusal to attack the root cause and instead look for reasons to attack others will make it impossible to "win" the "Global War on Terror", mainly because it is abstract and made up, but also because America is fighting a different war that the terrorists are fighting. Paths don't cross this way, and a resolution will not be made. There is a major disconnect in cause and effect in the eyes of the administration and those 
of the "terrorists". For example, in President Bush's State of the Union address in 2005 he named Iran, Iraq, Syria and others as "potential targets" and dangers who, it is alleged either have or are likely to acquire WMD, which hasn't been proven. Whereas North Korea actually has weapons and they have declared so, but what they don't have is oil, or a strategic place for America perhaps and therefore they are simply overlooked and are to be dealt with "diplomatically" (Dalby 2005a, p. 19)

In the opening paragraphs of the 2002 NSS it is stated, "while we recognize that our best defense is a good offense, we are also strengthening America's homeland security to protect against and deter attack" (White House NSS 2002, p. 5). Fear is instilled to first lay out the groundwork for the rationalization of pre-eminence.

"We must adapt the concept of imminent threat to the capabilities and objectives of today's adversaries. Rogue states and terrorists do not seek to attack us using conventional means" (White House NSS 2002, p. 5).

The bottom line of the Bush Doctrine, articulated in the NSS is

"The greater the threat, the greater is the risk of inaction - and the more compelling the case for taking anticipatory action to defend ourselves, even if uncertainty remains as to the time and place of the enemy's attack. To forestall or prevent such hostile acts by our adversaries, the United States will, if necessary, act pre-emptively" (emphasis added) (White House NSS 2002, p. 17).

Not only is preventive war part of the Bush Doctrine, but also so is perpetual war. Elden argues, "an open-ended script for the global war on terror was clearly envisioned" (Elden 2009, p.16). Donald Rumsfeld had directed his staff to "go massive. Sweep it all 
up. Things related and not", having in mind a bigger picture for U.S. policy (Ibid). Shortly after 9/11 Bush announced that "our war on terror begins with al Qaeda, but it does not end there. It will not end until every terrorist group of global reach has been found, stopped, and defeated" (Bush 2001 as cited in Elden 2009, p.16). It is not possible to defeat every single terrorist, group or even every nation that supports terrorism. It is impossible to destroy an ideology, which is what Bush set out to do. Most likely, knowing that this would not be a realistic end, however presenting it as such, a case for perpetual war is made. Bush is introducing the idea that from now on, because the world has so drastically changed, and the geographical perceptions of danger had shifted, and with the events of $9 / 11$ there are no limits. Gaddis writes that America "can no longer respect the sovereignty of any state that harbours terrorists; it must preempt such threats wherever they appear; it will extend democracy everywhere" (Elden 2009, p. 69).

Terrorism is an ideology, and a means, and so it can be found everywhere; therefore everywhere is also a threat, according to Bush. "Sovereignty over territory became both a privilege and a liability", writes Elden (Elden 2009, p.3). It is a privilege for the dominant powers like the U.S. who use it as legitimation for self-defence, and a liability for those states who have non-state actors operating within their boundaries - it puts many states at risk for attack (Ibid). There may be several non-state actors, within nation-state boundaries, defined as "terrorist", and America has taken it upon itself, for the "benefit of the world", to rid the world of such people/groups. This compromises state sovereignty completely, as it is not only a given state's responsibility to control their internal affairs, nor to solve conflicts on their own. So long as the U.S. is able to justify that these 
people/groups are detrimental to the U.S. or world peace, they have reason to invade and attack, pre-emptively; something that before $9 / 11$ would not be so 'easy' to do.

In the preface to the NSS Bush declared that

"In a world that is safe, people will be able to make their own lives better. We will defend the peace by fighting terrorists and tyrants. We will preserve the peace by building good relations among the great powers. We will extend the peace by encouraging free and open societies on every continent" (Preface to the National Security Strategy 2002).

Two things are interesting to note here. First, the international community and "great powers" at large did not stand behind America in its conquest of Iraq. Furthermore by free and open societies, Bush is clearly referring to free and open to American interests. Secondly, the wording is almost identical to previously produced PNAC documents. Especially the idea of "preserving the peace", a phrase used in several of the PNAC documents, that are published years before $9 / 11$ and the Bush Doctrine. The 9/11 Commission report asserts that the United States can "no longer think in terms of the 'home' and 'away' game. There is only one 'game'. "Away" needs to be treated as "home" (Elden 2009, p.20). Written in the 9/11 Commission report,

"In this sense, 9/11 has taught us that terrorism against American interests "over there" should be regarded just as we regard terrorism against America "over here." In this same sense, the American homeland is the planet" (National Commission on Terrorist Attacks 2004, p. 362).

It emphasizes that the entire world should be treated as if it were a part of America and that it is their responsibility to protect this extension of America, which this document 
suggests, is the entire planet (Elden 2009, p.20). Not only is this protection as in defensive strategies, but offensive as well, as intervention may be necessary.

Alongside pre-emption in the Bush Doctrine is unilateralism. As made clear in the NSS 2002, it states that although the United States will make attempts to gain the support of the "international community", if they do not agree with their cause, then they will go it alone.

"While the United States will constantly strive to enlist the support of the international community, we will not hesitate to act alone, if necessary, to exercise our right of self defense by acting pre-emptively against such terrorists, to prevent them from doing harm against our people and our country" (emphasis added) (White House NSS 2002, p. 6).

Basically what this means is that the potential is there from the US to act unilaterally in "preventive war mode" without sanction form the UN or any other organization (Dalby 2005a, p. 14). September $11^{\text {th }}$ has opened up several doors for foreign policy initiatives. In Bush's post 9/11 world, deterrence is no longer possible because of the attacks on American soil; therefore they have to be offensive. "It implies the right of Americans to decide when and where to attack potentially dangerous powers (Dalby 2005a, p. 18). This is made evident in the 2003 State of the Union address:

"The United States will ask the U.N. Security Council to convene on February the 5th to consider the facts of Iraq's ongoing defiance of the world. Secretary of State Powell will present information and intelligence about Iraqi's -- Iraq's illegal weapons programs, its attempts to hide those weapons from inspectors and its links to terrorist groups. We will consult, but let there be no misunderstanding: If Saddam Hussein does not fully disarm 
for the safety of our people, and for the peace of the world, we will lead a coalition to disarm him" (Bush 2003).

Hand in hand with pre-emption and unilateralism, is the renewed idea of "American global leadership" or "America the (global) policeman". Mentioned in several documents and speeches, Bush emphasizes the idea of America's "responsibility" to protect the peace both within and outside its own borders. Some have called this "Pax Americana" others have called it the "American Imperial Mandate". The basic assumption of this idea is that the United States is "a different place, a unique state with its role in history as the guarantor of the future" (Dalby 2005a, p. 15). Because America didn't have a choice in having this responsibility, the only choice it has now is to live up to it. As Dalby puts it, America "has a unique role to play in bending the world to its rule for its "own good"" (Ibid). Worded more vaguely, the NSS states, "as we defend the peace, we will also take advantage of an historic opportunity to preserve the peace. The United States will build on these common interests to promote global security" (White House NSS 2002, p. 3).

Similarities between these examples found in documents constituting the Bush Doctrine can also be found in the official 9/11 Commission Report, and more specifically, in its suggestions. The official 9/11 Commission Report concluded

"America stood out as an object for admiration, envy, blame. This created a kind of cultural asymmetry. To us, Afghanistan seemed very far away. To members of al Qaeda, America seemed very close. In a sense, they were more globalized than we were" (National Commission on Terrorist Attacks 2004, p. 340). 
To present America as an object of envy, which evildoers seek to ruin in spite; placing no blame on U.S. policies, and making everyone that is "against" America out to be fanatics who despise freedom is ignorant. No one is trying to justify what bin Laden and al-Qaeda did on September $11^{\text {th }}$, or any other terrorist attack by any group, however, being blind to address the root causes of these issues will further perpetuate the problem, not resolve it.

Former CIA operative Michael Scheur suggests that America is hated in much of the Islamic world because of specific U.S. government policies and actions, not out of some type of envy. Scheur notes six reasons why widespread hatred for America exists among Muslim nations. They are as follows: One is "U.S. support for Israel that keeps Palestinians in the Israelis' thrall. Second, he names the presence of the "U.S. and other western troops on the Arabian Peninsula". Third is the American occupation of Iraq and Afghanistan. Fourth is U.S. "support for Russia, India and China against their Muslim militants" and fifth is U.S. "pressure on Arab energy producers to keep oil prices low". The sixth and final reason Scheur gives is "U.S. support for apostate, corrupt and tyrannical Muslim governments" (Elden 2009, p.35).

In response to critics, many who use several of the six points outlined by Scheur, Bush responded in 2005 as follows:

"Over the years these extremists have used a litany of excuses for violence - the Israeli presence on the West Bank, or the US military presence in Saudi Arabia, or the defeat of the Taliban, or the Crusades of a thousand years ago.... We're facing a radical ideology with inalterable objectives: to enslave whole nations and intimidate the world. No act of ours invited the rage of the killers - and no concession, bribe, or act of appeasement 
would change or limit their plans for murder.... Some have also argued that extremism has been strengthened by the actions of our coalition in Iraq, claiming that our presence in that country has somehow caused or triggered the rage of radicals. I would remind them that we were not in Iraq on September 11, 2001 - and al Qaeda attacked us anyway. The hatred of the radicals existed before Iraq was an issue, and it will exist after Iraq is no longer an excuse..." (Bush 2005 as cited in Elden 2009, p.35).

It is not only the Muslim world that feels that the United States has always meddled too far into its own business and that of other nations, but many non-Muslims would also agree that this has been the case (Elden 2009, p.39). Neither Bush nor his administration, or those before it, have realized that direct policies of the United States and the West generally, have contributed to the "hate" that they say the Muslim world has for them. The 9/11 Commission report echoes this view. For example, referring to the divide between Muslim nations and the West, the report concludes that

"Because the Muslim world has fallen behind the West politically, economically, and militarily for the past three centuries, and because few tolerant or secular Muslim democracies provide alternative models for the future, Bin Ladin's message finds receptive ears" (National Commission on Terrorist Attacks 2004, p 362).

The question should be asked of why it has fallen behind? Due to countless sanctions, wars and policies, the Muslim world, which was once far ahead of the rest, has indeed fallen behind. It is not because they are backwards or uncivilized, or fueled with hate for the rest of the world, but because of deeper reasons that previous administrations are not willing to explore. America has played a huge part in the shaping of the Middle East and other Muslim nations, via policies such as support for Israel, sanctions and wars, and does play a huge role in the "hate" created for themselves. Not to say that suicide 
bombers and terrorists have justification for their actions, but it is far more complex than the United States leads its citizens, and others, to believe.

The 9/11 Commission was supposed to be a non-partisan commission made up of an equal number of Democrats and Republicans, to assess the attacks, what went wrong, and how to prevent such disasters in the future. However, after reading the report, specifically the findings, much of the report echoes what the Bush administration was saying. One of the main is that the United States and its allies need to destroy Islamic terrorism, or the ideology that gives rise to it. This is documented in the report:

"The ... enemy is gathering, and will menace Americans and American interests long after [O]sama Bin Ladin and his cohorts are killed or captured. Thus our strategy must match our means to two ends: dismantling the al Qaeda net- work and prevailing in the longer term over the ideology that gives rise to Islamist terrorism". (National Commission on Terrorist Attacks 2004, p. 363).

Even the report rationalizes perpetual war indirectly, as it is not possible to kill an ideology. It is something that lives in the minds of others. America could attack every nation on earth if they wanted, but what good will it do? Things that are deeply embedded in a culture, or a nation, cannot necessarily be "killed". The only way to rid the world of these ideologies is through positive change and understanding. Even different policies, and more diplomatic solutions may not get rid of what generations of people are brought up believing. To make terror sound like something tangible and concrete is misleading. 
The 9/11 Commission report sits quite nicely with the Bush Doctrine, and many of its main principles, such as preemption and also promotes the idea of preserving the peace, as the whole planet is referred to as American soil. In addition to the report being created, more immediate measures were taken after 9/11. One of the most notable of these measures, and most important to this thesis is the USA PATRIOT Act.

The attacks of September 11th gave way for surveillance measures to be put into place that for a long time couldn't possibly be passed because of the fact that they would be too extreme, by any measure that we have seen in recent history. But with the looming fear of terrorists attacking from anywhere at anytime, the Bush administration used the fears of American people and sold the Patriot Act under the guise that some liberties must be suspended in return for security and safety. What is included in the Patriot Act is quite frightening to the prospects of American freedoms and rights. According to the act the President is authorized to use

"All necessary and appropriate force against those nations, organization, or persons he determines planned, authorized, committed or aided the terrorist attacks of 911 or harboured such organizations of persons, in order to prevent future acts of terrorism" (Paye 2006, p. 31).

What and who defines necessary and appropriate? The language of the Patriot Act is so vague that it could mean anything. By stating "those nations" as targets, it also crosses territorial boundaries. Suddenly, some countries are deemed to be legitimate targets and can be attacked in any way when authorized by the President. Terror has no territory therefore the policies of the United States cross all boundaries. Other similar phrases contained in the Act are "offense against the United States" or "reasonable grounds to 
believe" - again both are leaving an open door to any possibility (Paye 2006, p. 33). Under this Act, the FBI have unlimited power and no longer need a real reason, nor a warrant for many investigative activities. For example, the Act allows the FBI to obtain both incoming and outgoing electronic and telephone connection data. Now the government simply has to indicate that the information is related to an investigation concerning terrorism (Paye 2006, p. 33). The grounds for being "related" are completely subjective and have no real guidelines therefore everyone is at risk for invasion of privacy. Another example is that there is authorization for secret searches of residences or offices without notifying the person if there is reasonable presumption to believe that it hold information relative to a foreign power (Paye 2006, p. 34). Implementing such "emergency" measures into law changes the fundamental rules of the democratic state, making the state of emergency a permanent state of exception.

Immediately after the attacks of Sept $11^{\text {th }}$, President Bush declared a national state of emergency. A little over a month later the Patriot Act was passed into law as an emergency act that was set to be suspended after four years. The Patriot Act, reorganized relations between society and state.

"This change is affected first in the name of a state of emergency, of the obligatory war against terrorism", but ended up as a tool of repression, all in the name of security ......the patriot act represents the perfect example of this process of incorporating the exception into the law, into the legal order. It has an ideological function; it legitimizes a change in the political system"' (Paye 2006, p. 29).

The change that PNAC has been fighting for, for years and the measures that the United States government has wanted to implement for decades was made possible through the 
"state of emergency". The Patriot Act dramatically reduced standards for protecting freedoms and privacy has almost become non-existent (Paye 2006, p. 30). For example, the Act allowed for the government to search and seize any personal records without a warrant and without even showing probable cause (Raskin and Spero, p. 4). What is worse is that it made it a crime to tell anyone - not even one's family, or a lawyer (Ibid).

The Bush administration used the attacks as an opportunity for it to "recast American criminal and national security law into a power grab for the authority of the state against the individual and the accused" (Raskin and Spero, p. 7). Because homeland security had taken over every aspect of everyday life, rights and freedoms were put on the back burner. The President and his advisors persistently pressured the courts and Congress for a "restrictive reading of the Constitution" and other legislation such as the Freedom of Information Act (Raskin and Spero, p. 3). The language of the act is questionable. The punishable sentence for terrorist related activity has increased with the passing of the Patriot Act. However, as defined in the Act "terrorist" or "terrorism" as a legal conception is very ambiguous and can mean anything (Raskin and Spero, p. 9). Because there is no definitive way to label one a "terrorist", it leaves room to detain a broad range of subjects. On a larger scale, internationally, it leaves room to attack any nation. There is a trend in almost all the documents being analyzed (the NSS, the Patriot Act, the various materials making up the "Bush Doctrine", and the $9 / 11$ commission report): they are all vague, and there is a constant that a given label or phrase, such as "terrorist" can mean anything. This is very intentional because it allows for all pathways to be options and for the time limit to be infinite. 
After the Patriot Act was passed, Attorney General Ashcroft imposed strict sanctions on anyone deemed an "enemy combatant". One of the extreme measures was the secret mass detention of thousands of people. Because of the new legislation, anyone "suspicious" could be held without reason, especially applying to immigrants who could be held up to seven days for questioning (Raskin and Spero, p. 17). If they cannot find reason to detain them any longer than the seven days, the government can change the category of person by finding an illegal act like an expired visa or driver's license, something so minor that can put that person in a state of detention without bail (Ibid). By using the word "terrorism", the Bush administration made clear that "this government can and should use preventive detention against anyone it deems necessary to hold in detention" (Raskin and Spero, p. 18). Immediately after 9/11, roughly 5000 people were detained out of which only three were charged with any terror related crime. Of those three, only one was convicted and not of engaging in a terrorist activity or supplying monetary support but for "conspiring" (Ibid). There were more or less 5000 people detained for no good reason. The Justice Department under Ashcroft rejected "any concerns about human rights, about civil liberties, about fairness as simply aiding the enemy...as not even appropriate to be on the table" (Raskin and Spero, p. 18). This was especially evident after Bush's declaration that "you're either with us or with the terrorists". What is important to note is that there is no such thing as a "good reason" in wartime, or in a state of exception. The whole premise of the state of exception is that there are no laws, and no real rules to follow. Societies engaged in war do not follow the logic or rights, or law, but rather the logic of security and war. Even if there is a minimal 
chance that someone may even be remotely involved in terrorist like activities, the logic of security would require to detain them, hold them as long as possible, get any information necessary, and yes, in the end it might turn out it is for "no good reason". Part of the indicator that America was in a state of exception was precisely that - they began to follow the logic of war and security, and the rule of law, and the constitution were being replaced. It is important to note that these detentions and lessening of rights pertain disproportionately to Muslims and people of colour in the United States.

In 2005, four years after the Patriot Act was supposed to have expired, the act for renewal was passed. The renewal of the Patriot Act made it possible to incorporate measures into the law on a permanent basis that, since 2001 , had been justified by an "emergency situation" (Paye 2006, p. 30).

"While defence implies protection, safety and trust, prevention operates on the basis of permanent feelings of fear, anxiety and unease - [the Bush administration] used the fear of Americans after $9 / 11$ to justify all to come afterward" (Van Muster 2004, p. 147).

Sassen writes that the attacks of $9 / 11$ and the possibility of more attacks are real, however the question must be posed: have the extension of the Patriot Act and other such "emergency" measures have become an overextension, and is it an illegal overextension? (Sassen 2006, p. 179). The problem with Sassen's question is who would define what is illegal? If the Patriot Act is an American law, and the Sovereign may decide which laws may be suspended, which new ones can be created, and so on, is a tough question to answer. The sovereign doesn't need to justify the Patriot Act measures to anyone. So what would normally be illegal (taking away of constitutional rights for example) is 
technically not. If we are discussing what is legal and illegal on an international level, then international law is only as good as its enforcement. When the United States is the primary enforcer, it seems that although there has been an international outcry that the war itself, and many measures such as the Patriot Act are "illegal", who is going to stop it? Is it possible to go against the only superpower on earth? Sassen quotes Donohue as saying that for some the Patriot Act "represents the most radical change in police powers in decades, and codifies counterterrorist measures previously rejected by Congress as too intrusive" (Sassen 2006, p. 180). This makes legal what had previously been viewed as exceptional, and therefore the exception becomes the norm. For example, a target of a Foreign Intelligence Surveillance Act (FISA) search is not notified unless evidence is used in a criminal prosecution, and even then the defendant is not permitted to see a government explanation for the search making it impossible to raise questions pertaining to the legality of the search in court (Sassen 2006, p. 181).

September $11^{\text {th }}$ seems to have opened a lot of doors for other private investigations, searches, the withholding of certain information, not to mention violation of several rights of American citizens. Sassen writes that since 9/11 citizens are expected to be open to scrutiny while a growing number of government operation have become secretive (Sassen 2006, p. 181). The right to individual privacy and an open government are fundamental aspects of a liberal democracy that have since been taken away or diminished (Sassen 2006, p. 181). Since September 2001, the Environmental Protection Agency, the Department of Agriculture, and the Department of Health and Human Services have all been granted permission to stamp documents as "secret" (Sassen 2006, 
p. 181). While government agencies are given more rights to be secretive, Americans rights to their privacy have been taken away.

There are a lot of similarities between the NSS, Patriot Act, 9/11 Commission Report, and Bush and other top officials speeches. One of the main things to note is how vague the language is in all the speeches and documents. How loosely the words terror, terrorist, threat, danger, emergency and other related terms are used. These documents are all very open ended, implying that one thing can really mean anything, and therefore any action necessary is appropriate. Another similarity is that they all advocate the same thing: pre-emption, offensive strikes, and the idea that whatever is necessary will be done to protect America, no matter how intrusive of constitutional rights that may be.

The Patriot Act and its renewal in specific, signifies a backwards steps in the rights of the individual, and increased rights of government control. For an administration that preaches that big government is bad, and shouldn't intrude on the rights of individuals, it is quite odd that of any administration (Republican or Democratic), they have intruded the most. The way it is presented is unique; due to the "emergency" situation, it is only to "protect" Americans. As mentioned earlier, majority of Americans are okay with the trade off of rights for security. False fears are created for the purposes of presenting a situation where an emergency even exists. The renewal of the Act only normalizes the situation. Americans are not nearly as afraid now, as they were in September 2001, but the Act remains in tact, carrying on as if they are still in a state of 
emergency. The emergency has passed, and a state of exception has come in its place, where the absence of rules and rights is just a part of daily life.

The bipartisan 9/11 Commission Report echoed what the Bush administration had already planned for foreign policy, which is essentially what PNAC had proposed years ago, and similarly what was written in the Defense Planning Guide (DPG) of 1992. This new American policy, which has since been called the Bush Doctrine, dramatically changed foreign and domestic policies. The changes that occurred in the eight years of the Bush presidency were signs of a new America, an Imperial America. Many of those policies have stayed, even now, almost 10 years after September $11^{\text {th }}$. Repression in the name of security as Paye put it seems quite appropriate when describing the situation. When people feel their security is compromised, and their safety is at risk, it seems they will accept almost anything if that safety is promised to them. Now that the different aspects of the War on Terrorism, the Bush Doctrine, the Patriot Act, PNAC's influence and states of exception in theory have been discussed, the bigger picture is becoming clearer. How have all these aspects come together to create a situation where America has been transformed by the state of exception? This next chapter will explain how 9/11 was a window of opportunity- just an excuse that would place America in a state of exception. 


\section{CHAPTER 5}

\section{Weapons of Mass Distraction: How America entered a State of Exception}

"The emergency has been renewed in each subsequent year and Bush is attempting to produce a situation in which the emergency becomes the rule; in which provisional and exceptional measures are transformed into a technique of government" (Gregory 2006, p. 407).

Stemming from the fear of terrorism, weapons of mass destruction, further and potential 9/11's - basically fear of everything, the declaration of the war against terror shortly after 9/11 was one of the most significant moments in American and world history that changed the face of politics dramatically. Since Osama Bin Ladin and key players responsible for the September $11^{\text {th }}$ attacks could not be found, the Bush administration strategically decided to go after Saddam Hussein in Iraq - something they had wanted to do for over a decade. Perhaps what was not so noticeable and not in the front page of every newspaper was another war - the war on American rights and freedoms. Through the Patriot Act, the pre-planned agenda and heavy influence of PNAC, and the implementation of the Bush Doctrine a transformation was taking place. 9/11 was used as a massive distraction and an excuse for implementing a pre-planned agenda transforming America into being in a state of exception.

The term "Global War on Terror", creates a lot of issues because of how vague the term is and how wide ranging its implications are. It raises questions such as: what exactly constitutes terror? Who are the terrorists? Where are they? The biggest problem, as the Bush administration would soon find out, is that the terrorists are not in Iraq, Syria, Iran or Saudi Arabia - they are everywhere. How do you attack and defeat or even 
declare war upon every place? If terror is everywhere, then everyone is a suspect. It sounds confusing but in fact the vague language is intentional and made it ideal for the administration to accomplish everything that was set out by PNAC, which was essentially global dominance.

Due to its emphasis on prevention or pre-emption, the war on terrorism "institutionalizes the state of exception as a permanent aspect of the global order" (Van Muster 2004, p. 152) America's state of exception affects the entire world, if we see it from this angle. Borders are seen as just an impediment to a nation on the road to total global dominance, not another nation's land to be respected. They present an obstacle that must be minimized for their goals to be achieved. Its actions and policy decisions are not contained within in its territorial boundaries. The GWOT affected those in Iraq killed by American bombs, it affects those being detained in Guantanamo, Abu-Ghraib, and at home in America, and it affects the rights of Americans, which are taken away by the Patriot Act. There are no boundaries to terror and therefore there is no end to this war.

"The war on terrorism cannot be pinpointed in spatio-temporal terms; the time and place of terrorism are of the terrorist's choosing" (Van Muster 2004, p. 147). Terrorists 'win' when they inflict terror upon others, and in the permanent state of fear the Americans portray themselves to be in, they have already won. Since all "perceived dangers can be and are linked to terrorists", the war is never ending and under this guise America can continue its path to a new American Empire (Ibid). Bush's claim that to be safe at home means the world must be safe from terrorists everywhere is inherent in the 
Bush Doctrine (as can be seen in the NSS). The 9/11 Commission's report suggestions echo the Bush Doctrine in that they promote a continuous preventive war that keeps the United States in a permanent state of exception.

Taking advantage of the bipartisan unity right after September $11^{\text {th }}$, special powers were given to the president a few days thereafter $9 / 11$ was the window of opportunity that American think tank PNAC and present and past administrations were waiting for. As Suskind notes, "it so happened that administration lawyers had for months been incubating theories about how to expand presidential power", and 9/11 was their chance (Elden 2009, p.5). The initiative for the expansion of powers came from Cheney, which isn't shocking. On September $14^{\text {th }}$, Bush received powers to

"Use all necessary and appropriate force against those nations, organization, or persons he determines planned, authorized, committed, or aided the terrorist attacks that occurred on September 11, 2001, or harboured such organization or persons, to prevent any future acts of international terrorism against the United States by such nations, organizations, or persons" (emphasis added) (Elden 2009, p.5).

Not only is this incredibly vague like much of the language used in other documents, but it really solidifies the state of emergency as something that isn't going to be temporary. Implicit in this phrase is the ability to attack anywhere at anytime, and based on previous statements, for however long is necessary (any "future acts"). What is also implied here is that the United States must protect its own sovereignty and territory, and protect the territory of others, while infringing upon other nations' sovereignty. There has always existed a double standard for the United States. As the world's only 
superpower, they feel that they must protect the whole world from terrorists and other dangers. However vocal they make this point, it is just another reason for the interests they have in various parts of the world.

It is no secret that America is the most powerful nation on earth, and it is no secret that they have abused these powers in the past. There are several different levels on which American administrations have wanted such extreme measures implemented. Domestically, to have extensive control of their own citizens, which is made possible through measures such as the Patriot Act. Increased social control and monitoring in such an explicit way is impossible to justify, unless a dictatorship, or perhaps if such a situation should arise, perhaps an emergency, like 9/11 that would warrant such measures. On a global scale, they have political interests in several nations, and more obviously, interests in the resources of others, Iraq being a prime example. Iraq has the world's second largest oil reserve, and therefore an American friendly leader would benefit American interests greatly. Not only for the sake of resources, but also strategically, as Iraq is in the middle of the Middle East, and would give America greater control if they could station troops there permanently, and create a base. Of course, having a "friendly" Iraq would help ease tensions. However, invading a country and forcing policies upon them is no way to make friends.

The kind of international order that Bush and his administration seek for America is one where "law is merely one policy consideration among others" (Bhuta 2003, p. 15). Especially during an emergency, law is not considered to be a binding obligation, 
because nothing can stand in the way of American safety and freedoms. However, Bhuta notes that it is only a consideration in American policy, whereas when it is applied to the enemy, law is strict; it is "ferocious and uncompromising" (lbid). Given this double standard (one of many), Bhuta argues that the connections with Schmitt are obvious:

"The sovereign is that which determines (by virtue of its actual or potential defeat of any who would challenge it) the exception. Order is not a matter of authority, but a matter of will, and legality is derivative of the will of the sovereign" (Bhuta 2003, p. 15).

The links between PNAC and the Bush administration are crucial to America's transformation into entering a state of exception. Although it seemed that way, 9/11 was not the reason for the implementation of such measures; it was the long awaited excuse. Everything from surveillance, to military capabilities, to the invasion of Iraq were possibilities long before the attacks of $9 / 11$ - they were just on the back burner until something could legitimize their implementation.

Back in 1992, Lewis Libby and Zalmay Khalilzad (also members of PNAC) drafted "The Defense Planning Guide" (DPG) which articulated the principal objective of extending U.S. power in the world (Bhuta 2003, p. 18). It was withdrawn after it was leaked to the press, however these same ideas emerged later in various PNAC related documents. For example, it is made clear that there is to be no new rival to the United States, and in order to ensure that no new rival can emerge the document calls that the United States should actively prevent any 
"Hostile power from dominating a region whose resources would, under consolidated control, be sufficient to generate global power. These regions include Western Europe, East Asia, the territory of the former Soviet Union, and Southwest Asia" (Bhuta 2003, p. $18)$.

Additional to this objective is the following: the United States must

"Show the leadership necessary to establish and protect a new order that holds the promise of convincing potential competitors that they need not aspire to a greater role or pursue a more aggressive posture to protect their legitimate interests"(Bhuta 2003, p. 18).

Bhuta also suggests that the United States must deter any nations from aspiring to a larger global role (2003, p. 18). How is it that one nation can decide that no other nation is "allowed" to aspire to a greater role in the world? It is clear that principles of Empire are embedded into this document. Additionally, reference is also made for the need to "preempt the use of weapons of mass destruction by any other nation", a strong overlap seen both in the NSS of 2002 and earlier PNAC documents (Ibid). Gellman asserts, "the NSS reflects a strategic worldview 'substantially similar' to the DPG, but "this time, they think they can pull it off" (Ibid).

The NSS of 2002 reiterates two other main themes from the DPG, which are the maintenance of unrivaled military power and the necessity of preventive wars against threats to US interests (Bhuta 2003, p. 19). Emphasized again by Defense Secretary Rumsfeld in 2002, in a speech he delivered to the National Defense University in Washington, he said "Defending the US requires prevention, self-defense and sometimes pre-emption. Defending against terrorism and other emerging $21^{\text {st }}$ century threats may 
well require that we take the war to the enemy." (Ibid). It is evident that there is overlap in the DPG, the PNAC documents, the members of the Bush administration's speeches, and the NSS. They are all leading to the same place.

9/11 opened the doors to all kinds of possibilities for the American administration. It is sad to refer to it as such, but it really served as a "window of opportunity" for those who had invested years, even decades into policy initiatives that could otherwise not have been pushed through. Writing in 2007, Paye asserts that

"Current affairs demonstrate that the decision concerning the exception is part of the order of law. Recent antiterrorist measures prove Schmitt right in his characterization of the state of exception as inscription of the exception in the law. One can even say that the current situation provides the real meaning to his thesis about the maintenance of the legal order by means of the decision concerning the exception" (Paye 2007, p. 238).

Paye says that the state of emergency exists for the long term as it has changed forms to become more socially acceptable, so to speak. It "emerges as a new type of political system, dedicated to defending democracy and human rights" (Paye 2007, p. 2). It takes on the guise of a humanitarian system, only there to protect, and in exchange citizens must be willing to give up their rights to maintain a democratic system, and secure their safety (Paye 2007, p. 2). This is a strange argument to make on several fronts, the most obvious begging the question, how can taking away democratic rights preserve a democracy? The Bush Doctrine is full of such contradictions, but somehow after $9 / 11$, most Americans were willing to give up some rights in exchange for security. The Patriot Act was one of the standout features of the Bush administration's policies that signified 
political hegemony, and a progression from state of emergency into being in a state of exception (Paye 2007, p. 40). Again, a situation that at random would be difficult to convince people to accept was more easily acceptable. This is largely due to the fact that Americans were in emotional shock the nation was scared and confused, making it a perfect time to start implementing some of these measures, most notably the passing of the Patriot Act.

One of the most talked about spaces of exception is Guantanamo Bay. Without going into too much detail, the 1902 treaty that gives the United States a "lease" of Guantanamo Bay, as to avoid U.S. laws for detainees is by today's governing norms and international laws, invalid on several grounds (Paye 2007, p. 49). It is "contrary to... self determination, and the doctrine of "unequal treaties" (Ibid). Paye writes that the "Executive has granted itself extraordinary powers that go against the Constitution of the US, and against international law" (Ibid). Again, international law is tricky, as it is hard to enforce, but there is still a consensus that something can be understood as "illegal" should it violate those terms, to everyone perhaps but the United States. However if the United States presumes itself to be in a state of exception, then nothing is "illegal" per se. It is in line with the logic of a state of exception actually. The situation in Guantanamo Bay parallels what is going on in America. Taking away the rights of Americans by writing it into law, the government has overstepped its boundaries. Although laws do still present a major obstacle to states of exception, there are still to many instances of rights being taken away, and presumably many more undocumented cases. It also taken away the rights of other nations around the world to self-determination, and their individual 
sovereignty by essentially attacking them, by codifying preventive war into its own foreign policy. As such, the United States may attack any nation it sees as a potential threat. Paye asserts that the Bush administration has made it possible to free itself from the safeguards of legal order (Paye 2007, p. 34). He continues by saying that

"The strengthening of the executive relative to the other powers makes possible the general and permanent suspension of the law. It is thus the instrument for setting up a state of exception, a state in which procedures that are exception to the rule become the norm and a state of generalized exception replaces the rule of law" (Paye 2007, p. 34).

The Patriot Act and various other rules pertaining to Guantanamo have an overall objective, which is essentially to legitimize these unusual situations by including them in a legal concept created by the executive power, which Paye says is "part of a larger strategy aimed at establishing, at the international level, a legal system of exceptions to the law" (Paye 2007, p. 53). Some of these laws have been gradual, only a few adjustments here and there that weren't really noticeable. $9 / 11$ changed everything; it allowed the administration to openly and drastically change some laws. The phrase "only in America" has a negative meaning now; one much different from the idea of the land of possibilities and great democracy.

Fundamental legal rights in some cases have been significantly diminished post 9/11. Several cases have been brought forward to the Supreme Court involving detainees, especially those in Guantanamo Bay prison. The result is always the same: a confirmation of the interpretations of Schmitt which suggest that the exception serves as the basis for a new legal system where the executive can grant itself legislative and judicial powers that 
weaken the formal separation of powers (Paye 2007, p. 72). The decisions of the Supreme Courts "strengthen the President's self-appointed role as judge and jury" (Paye 2007, p. 73). In a state of emergency, the President has powers to suspend the laws, and which may weaken the laws directly that protect fundamental rights and freedoms (Ibid). When the state of emergency is prolonged, and the measures stay the same even after the immediate emergency has subsided, a state of exception has transpired and therefore, it is a state without law (Ibid). It seems that it is mostly a space without law for certain racial and ethnic groups in America, namely Muslim men in specific and people of colour.

Laws such as the Patriot Act use law to establish a place outside the law itself. That in itself seems like a double standard, and majority of the time applies only to certain people. This may explain why the trade-off for rights versus security is acceptable with most Americans, as it does not affect them in the ways it would affect a young Muslim man living in America. Paye asserts that a generalized state of exception, as Agamben sees it, is in itself a contradiction. He says it is unstable because in the war against terrorism, the suspension of the rule of law is not an end in itself (Paye 2007, p. 73). Instead it gives the executive "the kind of authority allotted to judges: the authority to state and interpret the law, the authoritarian power of dictatorship" (Ibid). Some have already suggested that America has transformed into a dictatorship. Other terms commonly used are empire, hegemony and now, state of exception. These terms, if understood literally, may be an exaggeration. America is still governed by laws, it is not technically a dictatorship, and it is in a state of exception, but not itself a state of exception, as we would say Guantanamo is, for example. It is certain that we can see 
aspects of all the mentioned things, to varying degrees, but it is also important to recognize that the terms that are being used, are to prove a point, and maybe draw attention to the direction America could possibly head in.

After September $11^{\text {th }}$, a shift from "defense to prevention, re-action to pro-action, deterrence to intelligence, and events to eventualities" is documented (Van Muster 2004, p. 148). The change in attitude of the American administration is clear. Van Muster writes that contrary to defense, prevention focuses on insecurity instead of security; prevention and trust is replaced with a system of perpetual fear, anxiety and unease about the current world and all the unknowns (Ibid). The new system is centered on potential risks, and their likelihood, and is proactive on handling those potential risks, as opposed to focusing on real events and threats and handling those instead (Ibid). The Global War on Terror has replaced "the current order with a smooth, infinite space of endless surveillance, detection and prevention" (Ibid). What we saw progress was a state of emergency that progressed very quickly into a state of exception. "Due to its emphasis on prevention, the war on terrorism institutionalizes the state of exception as a permanent aspect of the global order" writes Van Muster (Van Muster 2004, p. 152). It doesn't seem that the state of exception is going to phase out, or that America will suddenly not be in a constant state of panic and fear. The changes that were made, and the transformations undergone have intentions to be permanent, and even now they are still a main focus in American politics. Paye reiterates this point:

"Within the context of the antiterrorist struggle, the type of government characterized by the state of exception is not temporary. It is part of a long-term war against a constantly changing enemy" (Paye 2007, p. 228). 
Such an abstract enemy such as Terror proves to be a perfect foil for the administration to extend the emergency situation. Terror will not ever stop existing, and as Paye wrote it will remain a constantly changing enemy. There will always be new grievances, new forms of terrorism, and new struggles. Terror has always existed of course, however 9/11 was unique because the world's only left standing superpower was attacked on their own soil. It was a shocking reality for many that terror can indeed come to America, in their busiest cities, most unexpectedly. When someone experiences something personally, his or her attitude changes: it becomes something real as opposed to something abstract or far away. So although Americans read and hear about terrorism in the news and the newspapers, when it was brought into their own cities, they were fear stricken. Terrorism was presented as a looming enemy, with potential to keep evolving and changing, and therefore a unique opportunity to change the politics of America was also present.

Wolin writes that

"Like previous forms of totalitarianism, the Bush administration boasts a reckless unilateralism that believes the United States can demand unquestioning support, on terms it dictates; ignores treaties and violates international law at will; invades other countries without provocation; and incarcerates persons indefinitely without charging them with a crime or allowing access to counsel" (Wolin 2003).

Wolin's view is a pretty accurate description of a state of exception, in harsher words perhaps, but nonetheless it covers all the aspects of the Bush Doctrine, and what has transpired policy wise in America post 9/11. He also asserts, "in institutionalizing the 
"war on terrorism" the Bush administration acquired a rationale for expanding its powers and furthering its domestic agenda" (Wolin 2003).

The changes in policy in America under Bush are definitely an abuse of power. Vulnerable to the fear of more attacks, based on what was told to them, the Bush administration took advantage of the American public during this time, and implemented an agenda that was already in the making. Again, it is important to note that it was not reactionary. The Patriot Act, foreign policies regarding the Middle East and Iraq, the "Axis of Evil" and other things we saw emerge during the time of the Bush administration were by no means an immediate reaction to the events of $9 / 11$. September 2001 served as an opportunity, a very unique one, to implement a blueprint.

As a state of exception stems from necessity, Necessity takes on two meanings in this situation. One, that it knows no law, as a state of exception is a lawless state. Second is that necessity creates its own law, so as many of the laws were suspended in America, and international laws were violated, new laws were created regarding foreign powers, their sovereignty and rights, most evident in the invasion of Iraq. Pre-emption was the new law, the new norm for dealing with all "rogue" states, according to Bush. On a similar note, both meanings of the term "exception" are exemplified in Bush's America. One, of course being the state of exception that has been most present throughout this argument, but also the exceptionalism of America. The notion that it is just their obligation, right or destiny to be an exceptional state has come through in many of these situation, most evidently in the words used by Bush himself. 
This is one of many double standards discussed throughout this thesis. Where the rules do not apply to America, they apply more strictly to other nations. American can have weapons, other nations' cant; America can infringe on the sovereignty of others and invade their countries, but other nations cannot; America can outright violate international law, whereas heavy sanctions will be imposed upon those nations who attempt to do the same. These are but a few examples of the endless double standards that exist for America.

There is a lot to be learned from watching the events of the War on Terror unfold. One is an important distinction that Agnew pointed out regarding sovereignty. Sovereignty has an external dimension, and is most evident in the example concerning the invasion of Iraq. Although the internal affairs of a state are not the business of others, if an outside state does not recognize it as sovereign, then invading it for whatever reason seems to have some sort of justification. That justification of course was really only present in the eyes of America, however, they used it as a legitimate excuse for themselves, and maybe a few others (John Howard, Tony Blair and Stephen Harper for example). After no WMD were found, it changed into humanitarian reasons, and the poor treatment of citizens by the leader of Iraq became the central issue, and "reason enough" for America to have gone into Iraq. There should be a consensus on this issue of sovereignty, because even if external recognition is needed, it must be from the international community at large. The United Nations recognizes Iraq as a sovereign state, and America alone cannot determine that sovereignty irrelevant. Regardless of 
whether it is right or wrong, Agnew's argument, especially given this situation, reminds us that strict territorial boundaries do not always define who has sovereignty within them.

Elden and Agnew, two of the most prominent geographers differ when it comes to theories concerning territory-sovereignty links; they contrast in regards to how territory and sovereignty link. Elden has more traditional views on territory. He supports the argument that territory is the "container" in which sovereignty operates (Elden 2009, p. 177). For Elden, sovereignty, who rules, how they rule and whom they rule are dictated mostly by territory. However, he also recommends that this concept needs to be revisited, because as he says, "internal competence cannot be preserved when boundaries because this prous" (Elden 2009, p. 177). He argues that we should look into the details of that argument instead of the fact that territory no longer matters. Elden seems to have some loose ends when it comes to his views on territory and sovereignty. He concludes his book by asking if sovereignty of a state is limited, can its spatial extent remain unquestioned? (Elden 2009, p. 177). This is assuming that a state's sovereignty is dictated by its territory. He is advocating a rethinking of sovereignty-territory, while recognizing that territory is still the 'container' that sovereignty fits into.

Agnew, in contrast, as we saw before has a more versatile and more contemporary view of sovereignty. Just a reminder of what Agnew claims; "sovereignty is neither inherently territorial nor is it exclusively organized on a state-by-state basis" (Agnew 2005, p. 437). Agnew asserts that territory is not the only container for sovereignty and that in our world today, such neat boxes cannot be drawn regarding such contentious 
issues. Especially regarding terrorism and states of exception, territorial boundaries do not necessarily identify who has sovereignty within them. As several terrorist networks, guerilla movements, and civil war examples have demonstrated to us both now and in the past, state forces are not the only ones or sometimes even not the dominant ones with control in a given territory. Regarding states of exception, America is a prime example of how one nation can use force upon another and dictate the rules, like in Iraq. Agnew's regimes of sovereignty seem to present a more realistic outlook on the territorysovereignty relationship today. As such, Agnew would disagree with the notion of Bush as the sole "decider", or Schmitt's theory that reduces sovereignty to he who decides the exception. Agnew's more realistic view would suggest that deciding on the exception is only but a part of sovereignty. There are so many different "regimes" of sovereignty that to reduce sovereignty solely to the idea of the exception would be a narrow view, one that is not representative of today's world.

One nation should not be able to unilaterally decide what is right for the entire international order, however Bush would probably argue differently. In his view, given America's unique role and "responsibility" to protect world peace, many actions were taken by his administration that are considered violations of international law, according to the U.N. Even within his own nation, violations of the constitution in the passing of the Patriot Act signified a very authoritative attitude. References to himself as the "decider", especially in relation to Schmitt's idea of the sovereign, really solidified those theories of the sovereign, and of states of exception. Additionally, as some have suggested, America shows signs of being a dictatorship, with Bush declaring himself as the decider. More 
importantly that means that the policies, both domestic and foreign, are in the hands of one person. It is only his judgment that will matter, which removes the significance of the democratic system of checks and balances, and makes it seem symbolic.

No matter if one is a political scientist, a geographer or a lawyer, states of exception are very difficult to define. On the one hand states of exception are lawless states. But on the other hand, they are made up of all sorts of laws, except those laws are used to place their actions outside the "regular law". So something ordinarily illegal is legal, but only because the law has placed that specific action outside the law itself. These laws need no justification and the legitimacy of them derives from the sovereign himself. However the problem of understanding states of exception as a "legal" term is that if the suspension of laws are written in a legal form, and justified as such, does that make a state of exception a legal state? Gregory argues that law during wartime has a “double character". He writes,

"On one side, law trails in the wake of war, re-defining legitimacy and so regulating the future conduct of war... On the contrary, it has become 'a law of firm rules and loose exceptions, of foundational principles and counter- principles', which, at the limit, 'offers the rhetorical - and doctrinal - tools to make and unmake the distinction between war and peace"" (Gregory 2010, p. 178).

Gregory asserts that law can be simultaneously strengthened and weakened in times of war, and exception, and can re-make law. Whether that re-making benefits citizens or not is questionable. In the case of the exception in America, many of the laws protecting rights and freedoms have indeed been suspended, and new laws such as the Patriot Act 
have been put in place, but that being said, there are still laws that can be used as a tool to fight some of that repression.

The debate about states has been going on for centuries, and the answers are not so clear. In this specific case, Bush codified the suspension of laws into legal documents. It is possible that they are codified as to be able to defend the suspension of laws and freedoms. It is a fact that laws were suspended and that freedoms were taken away.

However, it is also a fact that that America, the nation, is not Guantanamo, the Prison. Americans have experience a drastic change in their laws and rights, but there is still hope. There are still tools available, through the use of law, to resist states of exception and violations of rights. Although there are many examples against this point, and few that would suggest that the law can still be used against the government, Gregory argues that in fact law can be used as a resource to combat states of exception. The fact that these laws and their consequences are still being debated, implies that there is still political debate, and an opportunity to fight back, however small that may seem. Laws are still as important as before, and are the centre of attention, maybe more so than ever before. For example, people are still being taken to court, even in the cases of the War on Terror, which means that others are still questioning the rule of law, and trying to use it to their advantage whenever they can. Gregory writes on this point:

"...The law is not outside violence, and that the 'war on terror' twists their embrace into ever more frenzied and furtive couplings... This means, among other things, that law becomes the site of political struggle not only in its suspension but also in its formulation, interpretation and application" (Gregory 2006, p. 420). 
Gregory gives us an example of a court case in 2006, where a court ruling denied the military tribunals, which were set up in attempts to try the Pentagon's prisoners as illegal under federal and international law. The court ruled that the President had "exceeded the bounds placed by Congress on his executive authority though the Uniform Code of Military Justice and its incorporation of the Geneva Conventions" (Gregory 2006, p. 420). This was seen as "'the most significant rebuke' to the President's assertion of executive power since he took office and 'a sweeping victory for the rule of law" (Ibid). This was a reminder, Gregory says, that "nobody in enemy hands can be outside the law" (Ibid). Although such cases have also resulted in the opposite, there is still the potential to use law as a tool for fighting the "lawlessness" of the state of exception. To conclude on this point, Gregory writes, "there is nothing ineluctable about the triumph of the security state or the generalization of the space of exception"; law very much exists, but more people have to fight to keep it working for them, and not the state (Gregory 2006, p. 421).

However to justify whether or not it can be defined as a legal state or not is within the grey zone, and geographers and other theorists alike have had, and will continue to have difficulty in being definitive with any answer. To legitimize an ongoing situation, Bush used war as the excuse. After 9/11 and any real threat of terrorist attacks had subsided, the state of emergency was still ongoing. War was being used to perpetuate the current order, and justifying a state of exception. Back to Schmitt, the war on terror was a means to an end, and during this process America moved into being in a state of exception. 
The exception can now be seen in a different light, through the lens of critical geopolitics. It can almost be thought of as a hybrid model to examine states of exception and the affects of $9 / 11$. The combination of law, sociology, geography, international relations and political science come together in this thesis to critically analyze what has transpired over the last two decades. Critical geopolitics has shows us how fears and hopes were used to manipulate the public into war and into giving up their rights and freedoms. It has also allowed us to understand the propaganda behind "tabloid geopolitics", and how the boxes that we categorize our politics and our lives into have been constructed, why they have been constructed, and how that construction affects our reality. Critical geopolitics also sheds light on the Imperial ambitions of the United States. It asks that we question why as an international community we even take for granted that America is or global protector, policeman and dictator. These imperial ambitions were always brewing, but post $9 / 11$ a new era of global politics emerged, and a new America emerged. One that acts unilaterally, preemptively and much like that of an Empire.

From the language that is used from "homeland security" to vague definitions of terror and terrorists, geopolitical thinking uncovers that their use is intentional and purposeful. Through all this, critical thinking, and critical geopolitics wants us to question power. Sovereign is he who decides the exception? It is not so straightforward anymore, or maybe it never was. In the complex, and what is now called "post $9 / 11$ " world that we live in, Schmitt's theories are increasingly contested, and new theories 
emerge on how to analyze politics. Critical geopolitics allows us to question the exception, the rulers, the system, and the taken for granted beliefs that form our everyday opinions. The exception is a complex issue that in every specific case has a history, politics and geography to it; critical geopolitics has allowed us to explore those connections in order to better understand this entangled topic. The final chapter will discuss the implications for territory, geography, law and sovereignty, how this state of exception has changed America, and the world. 


\section{CONCLUSION}

\section{Mission Accomplished}

When Bush declared a "war" on terrorism, a lot of rhetoric emerged about how this was a new war, different from anything else the world has ever seen. Based on this claim, it is then imperative that we ask the next question, is this "war" in fact a different war? Is it a new kind of war? If so, how is it different and new? Kaldor's answer to this question is worth considering, as it sheds light on some important differences. Many people said Iraq was a new type of war because of all the technology that was used, the new satellites, and internet technology, but Kaldor says its more than that; that it is "new" due to the social relations of warfare (Kaldor 2005, p. 491). "Old wars" are typically fought between states, WWII being an example of a classic old war. The new wars that Kaldor is referring to are ethnic wars, wars that are between state and non-state actors, involving enemy combatants. They are wars that involve religious warfare, and violence targeted at civilians (Kaldor 2005, p. 492). These are not wars carried out by our typical notions of soldiers in uniform. Kaldor argues that this should be the context in which to understand the War on Terror. She writes, "The War on Terror, like the Cold War, is viewed as a powerful crusade - freedom against totalitarianism. Indeed, global Islam is dubbed as a new totalitarian ideology" (Kaldor 2005, p. 495).

Still, the rhetoric of "good versus evil" is present, except the difference is not only in new technologies, but rather in the fact that "terror" is not necessarily represented by one state, there is no one place to attack. Additionally, Islam is not a nation and therefore 
does not have its own militia and uniforms in the typical sense. Terror is abstract, it can exist anywhere; it is an ideology, a means and a strategy. Iraq was chosen as a place to represent terror, so that something concrete would exist to wage war against. Kaldor further explains the difference between old and new wars in the following quote:

"New Wars deliberately violate all the conventions of Old War, as well as the new body of human rights legislation that has been built up since World War II. The key to dealing with New Wars has to be the reconstruction of political legitimacy. So, political legitimacy can only be reconstructed on the basis of popular consent and within a framework of international law" (Kaldor 2005, p. 497).

There are two important things to note here. One is that the international community at large did not support Bush's War on Terror, and international law was not adhered to the UN itself condemning it as an illegal war. Second, although the war was not popular on the international stage, domestically, a lot of efforts, and propaganda, was put into selling the war to the public, as noted earlier. Bush had public consensus when he went into Iraq, with a considerable percentage of the population believing that Saddam was either personally responsible for $9 / 11$ or had links to $9 / 11$. So if the question being asked is how is the War on Terror a new war, the above would suggest that based on the definition here of a new war, that this new global war fits perfectly into place under this category.

Kaldor writes, "Carl Schmitt would argue that there can be no political community without enemies" (Kaldor 2005, p. 498), and terrorism is certainly one vast enemy. As noted earlier, the Bush administrations attempts to bring the entire American citizenry together after $9 / 11$, by $9 / 11$ as the excuse did work for quite some time. Pointing fingers 
at a common enemy (i.e. terrorists, Osama, Saddam) did help gather Americans together, and rally support for the GWOT. Right after $9 / 11$, there was a unified political community where there were no Republicans or Democrats, but only "Americans". However, after sometime, that togetherness also faded, and even more so with the invasion of Iraq which further split the nation on the issue, especially as it finally resulted in no WMD being found. So indeed, on certain levels, the War on Terror does represent a new kind of war. It is a war that is abstract, yet far reaching, as it is "global" in nature. It has introduced us to the realities that war and conflict are not just between nation states anymore. Our concept of the enemy, of war, and of how to fight wars has drastically changed since 9/11. It was not only a wake up call to the United States, but to the world, that much has evolved since the days of WWII, and even since the cold war, and the War on Terror demonstrates a new kind of enemy.

What is also new is how danger is perceived. Bush declared that the geographical dimensions of danger changed after 9/11. Oceans no longer protected America from the evils outside their borders. He claimed that America could no longer be selective in the threats they choose to protect themselves again, because $9 / 11$ proved that anyone and everywhere could be a potential threat. Terrorism is the new enemy, and terrorism is not constricted by geographical boundaries. It doesn't have a nation or territory, so this danger was new, and new ways to deal with it had to be implemented. The idea that danger had changed became the excuse for launching the Global War on Terror, and Al Qaeda became PNAC's initiative for waging war against Iraq. The Patriot Act, Homeland Security, tighter borders and a new doctrine of preemption and preventive war all became 
consequences of a new danger, post 9/11. The geographical perceptions shifted dramatically, because as Rumsfeld said, everything was seen through the new prism of $9 / 11$.

The implications of 9/11 have also raised several questions around territory and sovereignty. Some of the debates have been about what territory means, if there is a "new" kind of territory that the terrorists identify with, has territory been deterritorialized, and other such issues. In the simplest meaning of the word, "territory is a political and legal term concerning the relation between sovereignty, land and people" (Elden 2009, p.xxvi). However, the word territory has been used in all sorts of contexts, much of them contradicting one another since 9/11 and especially after the invasion of Iraq. How do terror and territory relate? Post $9 / 11$ the relationship between terror, territory and sovereignty has become an area of particular interest to geographers.

These debates have regained a lot of attention in the wake of the terrorist attacks, especially in regards to terrorists and what kind of authority they command. Appadurai asks an important question about boundaries in relation to terror, suggesting that:

"Terrorists blur the line between military and civilian space and create uncertainty about the very boundaries within which we take civil society to be sovereign. Terror is a kind of metastasis of war, war without spatial or temporal bounds. Terror divorces war from the idea of the nation" (Elden 2009, p.54).

This is especially true when the war on terror is taken into consideration. The war on terror is not war on a nation state. Terror is a concept that is so abstract, but the Bush 
administration has manipulated at times into something concrete (such as Iraq or Afghanistan) and at other times left abstract for the purposes of being able to attack anywhere at anytime. But the phrase itself - war on terror - would support Appadurai's argument. Chomsky suggests the problem is that "you have to find a definition that excludes the terror we carry out against them, and includes the terror that they carry out against us" (Chomsky 2006, p.3). Maybe this suggests non-state versus state terror. If terror is carried out by the U.S. Army, it is war, but carried out by a non-state, nonmilitary force, it is just terror; something illegitimate.

Terror is not really confined to one territorial area and therefore declaring a war on it has sparked new debate on what territory means, and the implications of a global war on terror. Although the idea of deterritorialization has become more popular, Elden says instead there is a process of reterriritorialization, "the relation between sovereignty and territory is one that demands renewed attention, both in terms of its conceptual, historical, and legal background and because of the changing nature of the relation today" (Elden 2009, p. 140).

He continues on with the relationship between the two:

"The fracturing of the relationship between territory and sovereignty thus provides a profound challenge. Such a lack of territorial control is not merely of concern for the state itself, but for regional stability, and, potentially, for global security. Yet the forced continuation of unsustainable territorial entities perpetuates the problem...In this, we see the reason why territorial integrity is such an important issue in international politics, but particularly in the context of the "war on terror"" (Elden 2009, p. 116). 
Territorial integrity is not only important to the U.S. in this scenario, but also to the states that cannot control their own territory, creating lawless areas which can become a breeding ground for terrorist activities and groups to arise (Elden 2009, p. 116). This causes conflicts in the area of sovereignty, because The United States compromises the sovereignty of these nation states by invading them and taking over their governments until an acceptable government is "elected", as can be seen in Afghanistan and Iraq. The United Nations places territorial integrity at the centre of its Charter. It declares:

"All members shall refrain in their international relations from the threat or use of force against the territorial integrity or political independence of any state, or in any other meaner inconsistent with the purposes of the United Nations" (Elden 2009, p. 140).

It is clear to see how the invasion of Iraq was a violation of the Charter. The UN Charter was created for a reason; it sets out a clear understanding of international law based on sovereign equality of all states, internal competence for domestic jurisdiction, and territorial preservation of existing boundaries (Elden 2009, p. 140). It is also written in the Charter that "no territorial acquisition resulting from the threat or use of force shall be recognized as legal" (Ibid). Under the Geneva Conventions, America is actually now an occupying power. Given this, the situation in Iraq was not only a violation of international law, but of basic territorial and sovereignty rights. Elden writes that territories are "legal, actual, and emotive lands, whose integrity figures in all these registers", therefore invading a territory is an invasion of person space for those who have lived there (Elden 2009, p. 145). This definitely does not accomplish the goal of a less hostile Iraq, and the Iraqi people do not see it as "Operation Iraqi Freedom" but more 
so an invasion of their personal and communal integrity, which has in turn led to more hostilities.

The NSS 2002 defined a turning point for American foreign policy. Incorporated in it are basically rights to violate such laws and treaties as it sees fit. Elden asserts that the NSS is "the new Washington Consensus" (Elden 2009, p. 176). Although the United States and other dominant powers have never really respected territorial integrity of other nations, the NSS is explicit in its intentions regarding territorial sovereignty of other nation states. A territorial expansion is not what is at stake for the United States, writes Elden, but rather an attempt at preserving the territorial framings of existing states (Elden 2009 , p. 177). Territorial sovereignty is at the heart of this issue, and at the heart of international politics, relations and law for centuries. Elden stresses the importance of territory:

"Territory matters because it is seen to provide the "container" within which sovereignty is said to operate, because its extent limits what the state can do, and because its limits are the extent of the state" (Elden 2009, p. 177).

Territorial integrity "necessitates a rethinking of the sovereignty-territory bind" as the United States and its allies cannot claim an unlimited right to undermine the sovereignty of other states whenever they see fit (Elden 2009, p. 177).

The effects of the 9/11 attacks on American policy and other nations alike is an example about how the war on terror has transformed America, and in many aspects the 
world. Some have even argued a global state of exception. Marcuse echoes this point but adds that the consequences of $9 / 11$ are "not a change in direction, but a continuation of trends already well under way before September 11, reinforced and aggravated by the cover given by the so-called "war on terrorism"" (Marcuse 2004, p. 263). There are clear connections between PNAC, previous agenda's such as the Defense Planning Guide, the NSS and various addresses by Bush and his administration to America and the United Nations. The media has paid little to no attention to the connections, and most of the American public, and the international public have thought that such policies were in direct reaction to $9 / 11$. It was conceived that America had to suddenly impose several policy changes, implement harsh laws (such as the Patriot Act) and immediately "attack" the enemy. However we can now see that all of these were being planned, for decades, and 9/11 was the window of opportunity that the think tanks were waiting for. September $11^{\text {th }}$ was a long awaited excuse, and the actions of the Bush administration were not reactionary, they were already well planned out and just needed a reason to be implemented.

Following this thought Marcuse says that

"The "war on terrorism" needs to be read always as in quotes, because it is not in any conventional sense a war - no national enemy, no troops, no territorial goal as such, no confrontation in battles - with the war on Iraq having only the most tenuous connection to actual terrorism rationally related to the prevention of terrorism - they do not deal with the relations that real terrorism, they are not proportional to the actual threats from real terrorism, they are not based on reliable information, and they serve strengthening policy directions already well under way before Sept 11" (Marcuse 2004, p. 263). 
The implications for sovereignty and territory are but one aspect of this complex analysis. A discussion of the practical implications of the War on Terror will help ground this analysis and show how it effects people on a more personal level. The aftermath of 9/11 and the War on Terror would suggest that this has really become a global phenomenon; everyone has been affected in some way. By declaring an "all-out war on what was called global terrorism" Bush clearly drew enemy lines, and defined for everyone what good and evil was (Patman 2006, p. 972). Bush created geopolitical categories that were to be seen as standard around the world; his notion of good and evil 'ought to be' everyone's notions too. Good would be those who support America, and evil would be everyone else. Patman reiterates this here:

"By presenting a world conveniently partitioned into binaries of 'good' and 'evil', the Bush administration was simultaneously defining itself as good and those who were terrorists or opponents of it as evil or bad" (Patman 2006, p. 973).

Proceeding with the good versus evil rhetoric, Bush's 2002 State of the Union address reflected "an arrogant impatience with foreign opinion of any kind" (Patman 2006, p. 975). If the opinions of others were not completely aligned with America's then, they were one of two things: evil or irrelevant. This type of attitude, that can be seen in other speeches and not just the State of the Union, reflect America's belief that they are exceptional, in both meanings of the word, as discussed by Hardt and Negri. Exceptional in that they are exempt from rules, and exceptional that they are an "example" for the rest of the world to follow. 
Patman makes an interesting point regarding the dynamic within the Bush administration. Patman has found that Bruce Bartlett, a former treasury official has revealed that

"The president has demanded unquestioning loyalty from his followers, his staff and his senior aides. Apparently, the president does not welcome discussions with staff that confront him with inconvenient facts" (Patman 2006, p. 977).

Even within his own administration, there is little room for debate. If Bush does not even entertain differences in opinion from his closest staff, international opinion is not going to be considered seriously.

Domestically, entering a state of exception has had several profound implications. Before $9 / 11$, Bush was already heading towards an unilateralist ideology and had already backed out of the Kyoto Protocol, unsigned the Rome treaty creating an International Criminal Court, withdrew from the Anti-Ballistic Missile treaty, among other things (Patman 2006, p. 972). After 9/11, Bush implemented Homeland Security, created (then renewed) the Patriot Act, and heavily promoted an "American Internationalism" (Patman 2006, p. 971). One of the most noticeable, and most practical implications of the War on Terror was the creation of Homeland Security and the passing of the Patriot Act. People were being detained like never before, and because America had entered a state of exception, a wartime mentality became permanent. This resulted in the retreat of rights of Americans, and especially those detained, if not taking them away all together on several occasions. Homeland Security, apart from being a physical department, costing billions of dollars a year, was also an ideological shift, as explained earlier. The idea of 
Homeland Security, and having a colour-coded system of threat levels is a psychological factor for Americans, and tampers with their emotions. They can be thrown into an immediate state of fear and panic if the colour changes, almost instantly. Now, that effect has lessened, but immediately after $9 / 11$, it took quite a toll on the emotions of the public. This perpetual fear, and efforts to keep citizens on their toes, helped the administration to achieve its goals, and reminded everyone now and then, that dangers are ever present, as the risk levels on the Homeland Security scale went up and down to "prove" this point.

The increase in torture, and widely publicized Abu Ghraib scandal is among the most public practical implications of Bush's War on Terror. Not only Abu Ghraib, but several other instances of torture were brought to surface. Not to say that torture wasn't present before the War on Terror, or $9 / 11$, but the public was made more aware of it, and instances and practices in torture increased. The irony is that the United States preaches freedom, democracy, human rights and equality, but doesn't exactly lead by example on all fronts. Torture is an example of the double standard in play. Many Americans after September 2001 supported or turned a blind eye to torture. It seems that to the many supporters of Bush, torture is somehow legitimized by the War on Terror, and by the attacks of September $11^{\text {th }}$. Hannah writes, "if there is an exercise of power that represents the antithesis of freedom and democracy, it is torture" (Hannah 2006,p. 622).

Hannah's argument poses the claim that torture is justified, and legitimized by the "ticking bomb scenario". What this essentially is, according to Bush, is the idea that thousands of dangerous terrorists, who are often supported by outlawed regimes, and 
"schooled" in the methods of murder are spread throughout the globe like ticking time bombs, that may go off at any time without warning (Hannah 2006,p. 622). Because these "crazy killers" are spread through the world, finding them and containing them is of utmost importance, even if that means engaging in torture to find out information on how they may be stopped. Hannah argues that the members of the Bush administration actually take this scenario of the ticking bomb quite seriously, and have drawn "permissive conclusions regarding torture" in order to justify it (Hannah 2006,p. 624). Again, Guantanamo and Abu Ghraib would be prime examples of the information about torture being in the spotlight, and much of the public turning a blind eye. There is an attitude that implies that they don't want to engage in torture, but if they have to, for the benefit of the world and American security, then so be it. Hannah quotes Michael Walzer in regards to this as recommending that they "condemn torture but be willing to resort to it anyway" (Hannah 2006,p. 625). The ticking time bomb scenario has been taken far too seriously, allowing torture to continue on. Nothing can justify torture, and the fact that the Bush administration tried to legitimize it on some level is disturbing to the prospects of human life, state violence and the relationship between the two. The ultimate form of violence is to end one's life, and for that to happen under state control, in these grey zones has been one of the most shocking implications thus far. There are two main reasons, according to Hannah, that justify torture. One is the ticking bomb scenario; if that fails, then they revert back to the original threat that future terrorist attacks are looming (Hannah 2006,p. 625). The point being that the administration always finds a way to use one of two (or more) reasons, which has been given legitimacy by $9 / 11$ and the War on Terror. 
Spaces of exception such as Guantanamo Bay, Camp X-Ray (later, Camp Delta), and Abu Ghraib have been created specifically for the purposes of detention and torture. Since it is a space of exception, there are no laws governing behavior within the camp walls. The only body the government really has to report to are its citizens, and only on ethical grounds. Because it is "legal" to torture within those spaces of exception, they are not at risk of any violation of law, and only have to legitimize such acts to the public, if caught.

The state has created a special space - and exceptional space, so they may decide who may live and who may die. The right to life, which is the most basic right, can be taken away without trial or reason. Most times, we as the public don't find out because these people are held in these special zones; these spaces of exception. Hannah writes,

"Crucially, the suspension of protections for life in a state of exception is used by the sovereign precisely to preserve life and the social order through which it is structured: some bodies may be placed outside the law, but this is done to protect the larger population" (Hannah 2006,p. 633).

All these measures are taken in order to preserve the life and safety of "those who count" by ridding the world of "those who do not count", potentially justified and even legitimized by the War on Terror, fear of terrorism, the psychological and physical impacts of 9/11. In Guantanamo for example, the prisoners are "located in the space "between the two deaths"- -legally dead (deprived of a determinate legal status) while biologically still alive" (Hannah 2006,p. 633). They are reduced to bare life (homo Sacer), and the entire space operates in what Zizek says is "an empty space that is 
nonetheless within the domain of the law" (Ibid). This demonstrates the epitome of a space of exception, and one of the scariest implications of the War on Terror - the right to kill, or let live. Hannah refers back to Hardt and Negri in his discussion of the War on Terror and torture:

"If, as Hardt and Negri suggest, the legitimation of violence is now retrospective, based on results, and the result the Bush administration is seeking is the neutralization of an unknown number of undiscovered ticking bombs in undisclosed locations, there is no limit in principle to the scope of imperial violation at all scales" (Hannah 2006,p. 636)

Pease argues that because the state of emergency is not subject to the rules it enforces, it is beyond a realm that is good or evil (Pease 2003). As mentioned earlier, many people were detained without access to lawyers, and if no criminal records could be found (according to immigration laws at the time) and the guilt of detainees could not be proven they would "transfer" these people to "Camp X-Ray", which Pease argues is a euphemism for extrajudicial measures (Ibid). These are extreme examples, but very real examples as well. The War on Terror has definitely opened more doors to methods such as torture, and sadly has become justification enough for many to continue these methods.

Psychological factors have a large role to play in the implications that $9 / 11$ has had on the American public in specific. Different geographies help us organize our world is different ways. They mold how we think of our world; what is good or bad, right or wrong, dangerous or safe, and so on. Actions, which seem simple, are actually motivated by intentions to influence how we categorize our world. For example Nick Megoran uses Judith Butler's argument in reference to the September $11^{\text {th }}$ obituaries to show us how 
some lives count, and some lives don't. Precarious Life, Butlers book, makes for an interesting analysis and questions who counts as human, what makes for a grievable life, and which lives are worth mentioning in obituaries (Megoran 2009, p. 70). As many of us have watched, every year on September $11^{\text {th }}$, the people who died on that day are named one by one on national television, for everyone to remember. Butler asks the question, what about all the other people who have died in this "War on Terror"? (Ibid). We do not know their names, nor do we know the names of the children or other victims of war in Iraq who have lost their lives. The obituaries are one subtle example of whose life is worth mentioning and whose is not. We tend to pay the most attention to what is mentioned, but just as important, is what is not mentioned. Megoran writes, "The obituary...is not just about nation building and the construction of a sense of "we" but disqualifies other lives as being not worthy of being noted let alone commemorated" (Megoran 2009, p. 70).

A comparison can be drawn here: just like the spaces of exception in the prison camps at Guantanamo and Abu Ghraib hold those lives that are "not worth" saving, the obituaries omit the names of those who are "not worth" remembering. Some actions are subtle, where others are overt and intentional in how they come across and what they mean. These are but examples of some of the stories that have emerged from America, and around the world regarding the implications of this Global War on Terror. How many people, and how deeply it has effected people is impossible to fit into one thesis. Some of the implications are far less dramatic, whereas some have changed the lives of nations and people irreversibly. That being said, these implications are important, and deserve 
recognition, because they help us conceptualize the War on Terror in a more personal, grounded way. Although the political and the personal are linked, it is not just about international relations, and different theories, it is also about the practical ways in which the War on Terror has affected the lives of many.

September $11^{\text {th }}$ presented new opportunities for America. Taking advantage of the fears and anxieties, and especially the shock that everyone felt right after the attacks, it was relatively easy to manipulate the public into anything that would calm these anxieties. It brought republicans and democrats together; people of all walks of life were affected in some way, especially those in New York City on that day. After such shock, people were willing to do or give into anything that would make them feel safer. Right away, the Bush administration implemented several measures that would otherwise be unacceptable by the public, or deeply scrutinized. They used the fears that people felt to con them into a permanent state of emergency that led into being in a permanent state of exception. Given all the confusion in the days after the attacks, the administration immediately started to pin point an enemy. It went from Osama to Saddam, once Osama couldn't be found. Sparke expands on this point:

"The geopolitical imagining of an "evil" other was undoubtedly key in this regard because it created an imaginative space where all sorts of illogical and pre-political feelings of fantasy and faith could be projected. But it was specifically fear of this evil other that was most instrumental because it made it possible for the President and his administration to connect widespread and visceral feelings of insecurity among Americans in the post-9/11 present to much narrower and calculative concerns with America's strategic future. It was in this way that the futurological fears ironically became a retroactive justification for war" (Sparke 2007, p. 341). 
This is demonstrated in several of the speeches given by Bush and his top officials. A very clear example of othering was taking places in how enemy lines were drawn. The following is a part of a speech by Rudolph Giuliani, then mayor of NYC.

"There is no room for neutrality on the issue of terrorism. You're either with civilization or with terrorists. On one side is democracy, the rule of law, and respect for human life; on the other is tyranny, arbitrary executions, and mass murder. Were right and they're wrong. It's as simple as that" (Elden 2009, p. 26).

By creating this image of terrorists, and scaring the public, it made it easier to pass laws such as the Patriot Act. By adding Osama and Saddam into the mix, it gave Americans a clear target to hate, and other. Terror is too abstract, and Americans needed to channel their anger over what happened towards a concrete enemy. In the larger scheme of things Hardt and Negri point out that

"Figures such as Osama Bin Laden, Saddam Hussein, etc are themselves very limited threats, but they are blown up into larger-than-life figures that serve as stand-ins for the more general threat and give the appearance of traditional, concrete objects of war" (Hardt and Negri 2004, p. 31).

Crafting the war on terror was a combination of many factors that weren't just a reaction to the September $11^{\text {th }}$ attacks. Such an extensive law such as the Patriot Act cannot be generated and passed within a month. Similarly, the contents of the NSS are not reactionary, although they appear to be so as they target Afghanistan and Iraq. After comparing the initiatives of the Bush Doctrine with PNAC documents and the DPG, there is almost a direct overlap in the themes from a decade ago to the ones mentioned in the 
more recent documents. This proves that $9 / 11$ was more so of a window of opportunity, then any kind of tragedy in the eyes of many politicians, backed by think tank PNAC.

PNAC did exactly what Benjamin and Schmitt wrote about regarding law and violence. The influence that they had on the Bush administration allowed them to reformulate American society. A new way of governing; a permanent state of war was created and became a part of everyday life, a new taken for granted belief. Violence was used to establish a new kind of law; a law that incorporates violence into it as "normal", both domestic and foreign.

This information is not secret; it just hasn't been publicized widely in the media. The connections were not explicitly made, and given the shocked state of Americans and the enemies that had been created for them, the general public didn't seem to question any of it. In fact several polls indicated that after September $11^{\text {th }}$, many Americans would be willing to give up a portion of their rights in return for security. It was also common to see polls in the newspapers that would suggest Americans easily confused Osama Bin Laden with Saddam Hussein, some Americans using their names interchangeably. The propaganda surrounding the Iraq war was huge, and the polls would indicate that much of it worked, at least temporarily.

Much of the evidence points signs in the direction of Imperial ambitions on the part of the United States. The NSS being the prime example of such ambitions as it promotes preventive war and unilateralism. To come back to a point made earlier, much 
of this not only signals a state of exception for the United States, but perhaps a global state of exception given that the repercussions are felt internationally. It has been named a global war on terror after all. What came to be known as the Bush Doctrine outlined and redefined an exceptional America and perhaps a global state of exception. However, Dalby points out that at the heart of the Bush Doctrine lies an internal contradiction which is that "its ambitions to global security are limited by the "constabulary" capabilities of its military and the inadequacies of its development and institutionbuilding capabilities" (Dalby 2005a, p. 20). Given its military strength, it is able to topple and destroy governments that it sees as threats to the global order, but it has failed in the reconstruction process, which is evident in the Iraq example (Ibid). "Pre-emption and the consequent denial of international law undermine support for American policies and hence exacerbate the difficulties of finding allied troops to do nation building", writes Dalby (Ibid). The unity after the attacks was short lived. The Bush Doctrine and policy decisions that were made both domestically and internationally caused a big rift within Americans (republicans and democrats) and between nations on the international stage. America had little to no support from the international community, as the United Nations deemed it an illegal war. The U.S. only really had Great Britain as its major ally, along side the "Coalition of the Willing" which wasn't very significant in size, or in what they had to contribute.

George W. Bush reiterated that America must fulfill its destiny to protect the world, and even more so its necessity to protect its people. After $9 / 11$, nothing was too extreme a measure to take to protect the homeland. We are reminded again of the quote 
"necessity knows no law" (Schwab 1970, p. 7). Everything after the attacks was seen as necessary, which is why it was relatively easy to pass so many domestic laws quietly without too much opposition. Keeping with the theories of a state of exception, and as discussed earlier, necessity is the basis. When something is "proven" to be necessary, there is a large consensus. For example, if someone is going to die, and in order to save his or her life it is necessary that you must cut a limb, there is more then likely to be a consensus that it should be done, because survival is everyone's ultimate goal. The constitutional rights are the limbs of America, and Bush and his administration presented the case that in order to save the nation, he must cut some limbs. Convinced that this is the best and only way for survival, most of the American public stood by him, for the first while at least. Bush was the clear sovereign; after all it was he who decided the exception. That is how Bush and his administration see sovereignty. They are not open to "regimes of sovereignty". Their notions of the concept are very conservative and traditional, and as a self declared war time President and Commander in Chief, he made sure that no ideas to contradict that would surface.

Not only was America in a state of exception, but it was also renewed as being an exceptional state. To clarify again, it is not that Americans were reduced to bare life, and the state of exception is not that of the camp, but a big difference can be documented during the eight years of the Bush presidency, and given the theory of states of exception, seems fitting to call it as such. So many double standards are documented which fit in with the theories of Hardt and Negri concerning America's double exception. September $11^{\text {th }}$ "helped" further the plans of this administration and PNAC in so many ways, it can 
be seen as a long awaited miracle for them. Opening the doors to endless possibilities, a harsh change in foreign and domestic policy, 9/11 was the ultimate excuse. A weapon of mass distraction, the events of 2001 changed American politics for years to come, allowing a slew of pre-planned agendas to be implemented. Even now with a new administration, one that on paper is in many ways polar opposite from the one before, and in a new era of "change" for America, it will still be hard to reverse many of the new laws implemented, not to mention the image America made for itself during the eight years under Bush.

The importance of critical geopolitical analysis in world changing events such as this one may help us discover hidden reasons for political choices, and not take for granted everything at face value. In a time of drastic change, we rely on the media to help us make sense of our world. In this case, they missed out many crucial connections and details, that if they were presented to the public as such, maybe a different course would have been taken. It is okay to question our leaders, in fact it is expected we do. As much as we would like to believe they do everything in our best interests, for our safety, security and protection, the harsh reality is there may be ulterior motives. Matthew Sparke wrote that

"Geographers have a responsibility to examine persistently, collaboratively, and critically the geographical grounds of hope and fear. We can help debunk false hopes and groundless fears, and in so doing we can also advance more sensible hopes based on more embodied and accountable experiences of fear" (Sparke 2007, p. 338). 
This thesis has strived to do just that. By incorporating geographers, political scientists, sociologists, and several other theorists, I have attempted to present a view that uses thinking outside the box. The Global War on Terror is a complex topic, but it seems to have been taken for granted. Why was it created? Why a global war? This thesis has answered these questions in a way that does not mask the reasons behind 9/11 and the terrorist attacks. The Patriot Act, Afghanistan, Iraq, the GWOT, the creation of "homeland security" and such were not reactions to $9 / 11$; that is what this thesis has tried to prove. They are strategies long ago planned, and 9/11 was an excuse, a strategic opportunity, a miracle, a window for the American administration to transform America, and the world in many aspects. Dalby writes,

"Strategy and political power have unavoidable geographical dimensions, but ones that are not always well understood by either politicians or the publics who advocate the use of military force. But first and foremost geopolitics is about the initial specification of the world in ways that subsequently facilitate policy in the world presented in that particular manner" (Dalby 2009, p. 235).

Uncovering these motives, understanding the geographical dimensions of power and security, and making the missing connections are a step forward in understanding, and maybe changing our world for the better. The first step only, but as geographers, an important one for knowledge is power, and without the knowledge and proper information needed to make a start, no change will be possible. 


\section{AFTERWORD}

\section{Change We Can Believe In?}

The Bush legacy is not going to be looked back on as a proud moment in American history. Some of the damage cannot be undone. Bush's legacy is one of unilateralism, pre-emption, and the isolation of America from the international community. It has marked the biggest reorganization of America's federal government since 1947 (Patman 2009, p. 223). From the creation of the Homeland Security department (only second in size to the Defense Department), to the passing of the Patriot act which violates constitutional rights, this administration has left a lot of fundamental changes, and a lot of cleaning up for the next administration.

Bush's election resulted in a rebranding of American national security, one which follows the thought that "security is fundamentally determined by the military means of sovereign states" (Patman 2009, p. 220). Patman calls for the next administration, i.e. Obama's administration to

"End the fiction that America can determine its own security in an globalizing world and move towards a multilateralist strategy for addressing the challenges of terrorism, in particular, and international security, in general" (Patman 2009, p. 211).

However, because the Bush legacy has dramatically changed certain aspects of the government, such as reorganizing and creating new areas within the government, some feel that Obama's task is much harder then assumed. A new leader may not mean a completely new ordering of the current government and how it functions. Lyncha and 
McCrisken argue that the structural changes to the military and the national security state under Bush can potentially restrict the Obama administration from implementing much of the change that they campaigned for (Lyncha and McCrisken 2009, p. 117). Lyncha and McCrisken write,

"[Obama will] clearly be a very different president from George W. Bush. But whether this difference can alter in any essential fashion the underlying forces of international politics will be the great challenge of the Obama years" $(2009$, p. 118).

What is hopeful however is that Obama seems to be a different kind of leader. And he is exactly that, writes Gibson, not a dictator, or aggressor, but a true leader (Gibson 2010, p. 12). Gibson also says that Obama is a sign of the maturation of the Imperial power (Gibson 2010, p. 12), still implying that America will still see itself as an empire. Like Lyncha and McCrisken, Gibson also thinks that the changes in foreign policy and the reorganization of the government left over from the Bush years will make it difficult for Obama (or any leader) to make significant changes, quickly (Gibson 2010, p. 12).

When people say that Obama is a very different leader from Bush, it might be that they are thinking in terms of how the world might have been different if Obama was President on 9/11. Maybe, we can hypothetically assume, that if Obama was president on $9 / 11$, there would have been a significantly different response. It is possible that Obama would have never declared a "War on Terror". The reality is, in year 2010, we are all involved in this 'new' war, and Obama has already pledged to continue fighting it. His support for social programs, health care, and other issues has already shown to be significantly different from his predecessor, but in terms of terror and the vow to defeat 
it, it seems that it may be only be a continuation of what was already put in place. As these authors have mentioned, it is too hard to reverse everything that was done in the eight years of the Bush presidency.

However, despite the difficulties Obama will and has already faced, his election does offer hope. The election of an African American has already signaled big changes in American attitudes. Obama has already demonstrated that he is moving towards a new American ideology, one that includes the opinions of the international community and takes them seriously. A multilateral approach in foreign policy is being brought back to the table. Gibson writes, "if Bush has proved anything, it is that unilateralism and arrogance will eventually undo America", and with that note Gibson, and many others feel that the Obama Presidency will usher in "a new era of intelligent, geographically literate international relations and engagements" (Gibson 2010, p. 13).

The immediate hope is that Obama's "geographic literacy" will be based on a far more complex understanding of today's world. Not only a post $9 / 11$ world, but a more globalized world in general that is made up of beliefs and faiths much different from that of America's. The premise for understanding the world, based on what Obama has campaigned on, and showed us so far, is not solely "us versus them" rhetoric. It is an understanding that goes deeper than America against the terrorists, or "freedom against evil" and other simplified versions of good versus bad that the Bush administration left us with. 
At his groundbreaking speech at the University of Cairo in 2009, President Obama broke this rhetoric, saying

"So long as our relationship is defined by our differences, we will empower those who sow hatred rather than peace, those who promote conflict rather than the cooperation that can help all of our people achieve justice and prosperity. And this cycle of suspicion and discord must end" (Obama 2009).

Obama's language promotes a new kind of sophistication, and a new kind of cooperation, much different to the polarizing language of Bush. Immediately after Obama continued by saying

"I've come here to Cairo to seek a new beginning between the United States and Muslims around the world, one based on mutual interest and mutual respect, and one based upon the truth that America and Islam are not exclusive and need not be in competition. Instead, they overlap, and share common principles -- principles of justice and progress; tolerance and the dignity of all human beings" (Obama 2009).

Obama's focus is on promoting similarities even between those nations, faiths and people who have many differences. Encouraging focus on commonalities will hopefully ease tensions, many of which were multiplied during the Bush years, and begin to bring together a very polarized world. Obama's election promises a lot of hope; maybe more than he can deliver, but it is too soon too predict his legacy. For now, this is all to be determined. 


\section{Bibliography}

Abelson, D. (2006). Capitol idea think tanks and US foreign policy. New York: McGill-Queen's UP.

Abrams, E., Bauer, G., Bennett, W., \& Bush, J., et al. (1997). Statement of Principles. Project For the New American Century, 3 June 1997. Available from $<\mathrm{http}: /$ http://www.newamericancentury.org/statementofprinciples.htm $>$.

Agamben, G. (2005). State of exception. New York: University Of Chicago Press.

Agnew, J. (2005). Sovereignty regimes: territoriality and state authority in contemporary world politics. Annals of the Association of American Geographers, $95(2), 437-461$.

Agnew, J. (2009). Globalization and Sovereignty. Lanham: Rowman \& Littlefield Publishers, Inc.

Altheide, D., \& Grimes, J. (2005). War programming: the propaganda project and the Iraq war. The Sociological Quarterly, 46, 617-43.

Barnett, T. (2003). The Pentagon's new map. Esquire, March 2003. Available from $<$ http://www.thomaspmbarnett.com/published/pentagonsnewmap.htm>

Barry, T. (2005). Bush's new freedom fighter Elliott Abrams: the neocon's neocon. Common Dreams.org. Available from $<$ http://www.commondreams.org/views05/0209-22.htm >

Bellamy, A. (2009). When is it right to fight? International law and jus ad bellum. Journal of Military Ethics, 8(3), 231-45.

BBC News. (16/09/04). Iraq war illegal, says Annan. Available from http://news.bbc.co.uk/2/hi/3661134.stm

Bhuta, N. (2003). A global state of exception? The United States and World order. Constellations, 10 (3), 371-91.

Blomley, N. (2003). Law, property and the geography of violence: the frontier, the survey and the grid. Annals of the Association of American Geographers, 93, 121-141.

Boot, M. (2001). The Case for American Empire; The most realistic response to terrorism is for the 
United States unambiguously to embrace its imperial role. The Weekly Standard, 15 October

Brophy, S. (2009). Lawless sovereignty: challenging the state of exception. Social \& Legal Studies, 18, 199-220.

Bush, G.W. (2002). President delivers state of the union address, January $29^{\text {th }}$. Available from http://archives.cnn.com/2002/ALLPOLITICS/01/29/bush.speech.txt/

Bush, G.W. (2002b). Bush: Don't Wait for Mushroom Cloud. Available from http://archives.cnn.com/2002/ALLPOLITICS/10/07/bush.transcript/

Bush, G.W. (2003). President delivers state of the union address, January $29^{\text {th }}$. Available from http://www.cnn.com/2003/ALLPOLITICS/01/28/sotu.transcript/

Bush, G. W. (2003b). President Bush meets with Prime Minister Blair, January $31^{\text {st }}$. Available from http://www.whitehouse.gov/news/ releases/2003/01/20030131$\underline{23 . h t m l}$

Bush, G.W. (2004). President Bush calls for renewing the USA PATRIOT Act, 19 April, available from $\mathrm{http} / / \mathrm{www}$. whitehouse.gov/news/releases/2004/04/200404194.html.

Bush, G.W. (2006) as cited in Henry, E., \& Starr, B. (2006). Bush: 'I'm the decider' on Rumsfeld. CNN. Available from http://www.cnn.com/2006/POLITICS/04/18/ rumsfeld/

Butler, J. (2006). Precarious Life: the Powers of Mourning and Violence. London: Verso.

Charles-Phillipe, D., \& Grondin, D. (2006). Hegemony or empire? The redefinition of US power under George W. Bush. Grand Rapids: Ashgate.

Chomsky, N., \& Achar, G. (2006). Perilous power: the Middle East \& U.S.. foreign policy dialogues on terror, democracy, war, and justice. New York: Paradigm.

Clausewitz, C. (1976). On War. (Eds.), M. Howard \& P.Paret. Princeton: Princeton University Press.

Dalby, S. (2003). Calling 911: Geopolitics, Security and America's New War. Geopolitics, 8, 61-86.

Dalby, S. (2005a). Geopolitics, grand strategy and the Bush doctrine. Singapore: Nanyang Technological University, Institute for Defence and Strategic Studies, October 2005. 
Dalby, S. (2005b). Political space: autonomy, liberalism and empire. Alternatives, $3,415-441$.

Dalby, S. (2006). Geopolitics, grand strategy and the Bush doctrine: the strategic dimensions of US hegemony under George W. Bush. In C.P. David, \& D. Grondin (Eds.), Hegemony or empire? The redefinition of US power under George W. Bush (pp. 33-51). Grand Rapids: Ashgate.

Dalby, S. (2009). Geopolitics, the revolution in military affairs and the Bush doctrine. International Politics, 46, 234-252.

Dalby, S. (2010). Critical geopolitics and security. In P. Burgess, (Ed.), Handbook of new security studies. London: Routledge.

Debrix, F. (2008). Tabloid terror war, culture and geopolitics. New York: Routledge.

Donnelly, T. (2000). Rebuilding America's defences: strategy, forces and resources for a new century. Project For the New American Century. Available from <http://http://www.newamericancentury.org/index.html>.

Durham, M. (2004). The American right and the Iraq war. The Political Quarterly, 75 (3), 257-65.

Elden, S. (2009). Terror and Territory. Minneapolis: University of Minnesota.

Gibson, C., Ramutsindela, M., Yamazaki, T., \& Mamadouh, V. (2010). Interventions on the meanings of the Obama presidency for US relations with global regions. Political Geography, 29(1), 5-16.

Gregory, D. (2006). The black flag: Guantanamo Bay and the space of exception. Geografiska Annaler. 88 (4), 405-427.

Gregory, D. (2010). War and Peace. Transactions of the Institute of British Geographers, 35 (2), 154-86.

Hannah, M. (2006). Torture and the ticking bomb: the war on terrorism as a geographical imagination of power/knowledge. Annals of the Association of American Geographers, 96, 622-640.

Hardt, M., \& Negri, A. (2004). Multitude: War and Democracy in the Age of Empire. New York: Penguin.

Kagan, R., \& Kirstol, W. (2000). Present dangers: crisis and opportunity in American foreign and defence policy. San Francisco, Calif: Encounter Books. 
Kaldor, M. (2005). Old wars, cold wars, new wars, and the war on terror. International Politics, 42, 491-498.

Kaplan, F. (2008). Daydream believers how a few grand ideas wrecked American power. New York: Wiley.

Kinzer, S. (2006). Overthrow: America's Century of Regime Change from Hawaii to Iraq. Toronto: H. B. Fenn and Company Ltd.

Krauthammer, C. (2001). The Bush doctrine ABM, Kyoto, and the new American unilateralism. The Weekly Standard, 4 June.

Laconte, J. (24 December 2001). Rumsfeld's just war; generals meet theologians at the Pentagon. The Weekly Standard.

Lyncha, T., \& McCrisken, T. (2009). Beyond Bush: A new era in US foreign policy? International Politics, 46, 115-118.

Mann, J. (2004). Rise of the Vulcans: The History of Bush's War Cabinet. Toronto: Viking

Marcuse, P. (2004). The "war on terrorism" and life in cities after September 11, 2001. In S.Graham (Ed.), Cities, war, and terrorism towards an urban geopolitics (studies in urban and social change) (pp.263-276). Grand Rapids: Blackwell Limited.

McKinley, M. (2007). Economic globalization as religious war: tragic convergence. Abington, Oxon: Routledge

Megoran, N. (2009). Colonizing commemoration: sacred space and the war on terror. In A.Ingram \& C.Dodds (Eds.), Spaces of security and insecurity (pp.65-85). Surrey, UK: Ashgate Publishing Limited.

Moseley, A. (2009). Just war theory. Internet Encyclopaedia of Philosophy, 10 February. Available from <http://www.iep.utm.edu/justwar/\#H3 $>$.

National Commission on Terrorist Attacks. (2004). The 9/11 commission report: the final report of the national commission on terrorist attacks upon the United States. Washington: U.S. Government Printing Office.

Nelson, M. (1999). The Evolving Presidency. Washington: Congressional Quarterly Inc.

Obama, B. (2009). Remarks by the President on a new beginning, June $4^{\text {th }}$. Available from http://www.whitehouse.gov/the press office/remarks-by-the-president-atcairo-university-6-04-09/ 
O Tuathail, G. Thinking Critically about Geopolitics in, O Tuathail, G., Dalby, S., \& Routledge, P. (2006). The Geopolitics Reader. 2nd ed. New York: Routledge.

Patman, R. (2006). Globalisation, the new US exceptionalism and the war on terror. Third World Quarterly, 27, 963 - 986.

Patman, R. (2009). Out of sync: Bush's expanded national security state and the war on terror. International Politics, 46, 210-233.

Paye, J-C. (2006). A permanent state of emergency. Monthly Review, 58, 29-37.

Paye, J-C. (2007). Global War on Liberty. New York: Telos.

Pease, D. (2003). The Global Homeland State: Bush's Biopolitical Settlement. Boundary 2, 30, 1-18.

Project for the New American Century. (2010). About PNAC. Available from http://www.newamericancentury.org/aboutpnac.htm

Raskin, M., Spero, R,. \& Ehrenreich, B. (2006). The four freedoms under siege : the clear and present danger from our national security state. New York: Praeger.

Sassen, S. (2006). Territory, Authority, Rights: From Medieval to Global Assenblages. New Jersey: Princeton University Press.

Schlesinger, A. (1973). The Imperial Presidency. Boston: Houghton Mifflin Company.

Schmitt, C. (1985). Political Theology: Four Chapters on the Concept of Sovereignty, Translated by George Schwab. Cambridge: MIT Press.

Schwab, G. (1970). The Challenge of the Exception: An Introduction to the Political Ideas of Carl Schmitt between 1921 and1936. Berlin: Duncker u. Humblot.

Sparke, M. (2007). Geopolitical Fears, Geoeconomic Hopes, and the Responsibilities of Geography. Annals of the Association of American Geographers, 97, 338-49.

The White House. (2002). The National Security Strategy of the United States of America. Washinton D.C.: The White House. Available from http://www.globalsecurity.org/military/library/policy/national/nss-020920.pdf

United Nations. (2010). Charter of the United Nations. Chapter 1: Purposes and Principles. Available from http://www.un.org/en/documents/charter/chapter1.shtml

Van Muster, Rens. (2004). The War on Terrorism: When Exception Becomes the Rule. International Journal for the Semiotics of Law, 17, 141-53. 
Williams, M. (2003). Words, images, enemies: securitization and international politics. International Studies Quarterly, 47, 511-31.

Wolin, S. (2003). A kind of fascism is replacing our democracy. Newsday, 18 July. 